\title{
Dynamic graciloplasty in perspective
}

Citation for published version (APA):

Rongen, M. J. G. M. (2006). Dynamic graciloplasty in perspective. [Doctoral Thesis, Maastricht University]. Maastricht University. https://doi.org/10.26481/dis.20060428mr

Document status and date:

Published: 01/01/2006

DOI:

10.26481/dis.20060428mr

Document Version:

Publisher's PDF, also known as Version of record

\section{Please check the document version of this publication:}

- A submitted manuscript is the version of the article upon submission and before peer-review. There can be important differences between the submitted version and the official published version of record.

People interested in the research are advised to contact the author for the final version of the publication, or visit the DOI to the publisher's website.

- The final author version and the galley proof are versions of the publication after peer review.

- The final published version features the final layout of the paper including the volume, issue and page numbers.

Link to publication

\footnotetext{
General rights rights.

- You may freely distribute the URL identifying the publication in the public portal. please follow below link for the End User Agreement:

www.umlib.nl/taverne-license

Take down policy

If you believe that this document breaches copyright please contact us at:

repository@maastrichtuniversity.nl

providing details and we will investigate your claim.
}

Copyright and moral rights for the publications made accessible in the public portal are retained by the authors and/or other copyright owners and it is a condition of accessing publications that users recognise and abide by the legal requirements associated with these

- Users may download and print one copy of any publication from the public portal for the purpose of private study or research.

- You may not further distribute the material or use it for any profit-making activity or commercial gain

If the publication is distributed under the terms of Article $25 \mathrm{fa}$ of the Dutch Copyright Act, indicated by the "Taverne" license above, 
Dynamic graciloplasty in perspective

Mart-Jan Rongen 


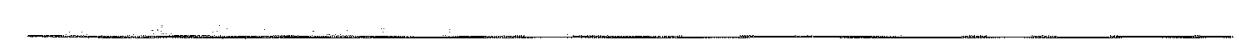




\section{Dynamic graciloplasty in perspective}

\section{PROEFSCHRIFT}

ter verkrijging van de graad van doctor aan de Universiteit Maastricht, op gezag van de Rector Magnificus,

Prof. Mr. G.P.M.F. Mols

volgens het besluit van het College van Decanen,

in het openbaar te verdedigen

op vrijdag 28 april 2006 om 14.00 uur

door

Martin Johan Gerard Marie Rongen 


\section{Promotor:}

Prof. dr. C.G.M.I. Baeten

\section{Copromotores:}

Dr. W.G. van Gemert

Dr. J.L.M. Konsten, afdeling Chirurgie, Viecuri, Venlo

\section{Beoordelingscommissie:}

Prof. Dr. P.B. Soeters (voorzitter)

Prof. Dr. Ph.E.V.A. Van Kerrebroeck

Prof. Dr. M. Kon, hoogleraar plastische chirurgie Universiteit Utrecht

Prof. Dr. L. Păhlman, hoogleraar colorectale chirurgie University of Uppsala, Sweden

Vormgeving en Layout:

D\&L graphics

www.dlgraphics.n!

Mustraties:

John Derwall

wwwdlgraphics.nl

ISBN-10: 90-8590-013-1

ISBN-13: 978-90-8590-013-9 


\section{CONTENTS}

1. Introduction 7

2. Long-term follow-up of dynamic graciloplasty for fecal incontinence 25

3. One-step versus two-step procedure in dynamic graciloplasty

4. Comparison of epineural and intramuscular nerve electrodes for the stimulated graciloplasty

5. Secondary coloperineal pull-through and double dynamic graciloplasty after Miles resection; Feasible, but with a high morbidity 73

6. The effects of high field strength MRI on electrodes and pulse generator in dynamic graciloplasty

7. Cecal access for antegrade colon enemas in medically refractory slow-transit constipation. A prospective study

8. Summary and general discussion

Samenvatting

List of abbreviations

Publications

Curriculum Vitae 



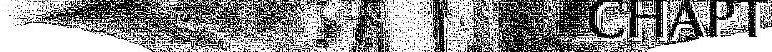

Introduction

2. 


\section{Fecal Incontinence}

Control over bowel movements is one of the first things in human life we learn to master. Normally we take fecal continence for granted and do not even think about this until something goes wrong. One could define continence as the ability to hold and to postpone defecation and to expel feces at a chosen time and place.

Fecal incontinence $(\mathrm{Fl})$ is an underestimated ailment. Social isolation usually accompanies the disorder. Recent community based prevalences are reported from $2.2^{1} 3.7^{2}$ and even up to $15.2 \%$ in women ${ }^{3}$. In more than half of the cases $\mathrm{Fl}$ is combined with urinary incontinence. The prevalence rises with age, suggesting degenerative changes. It is the second most frequent reason for admittance in a nursing facility ${ }^{4}$. Only a small number of patients present their complaints to a doctor. The majority is too embarrassed to report this spontaneously and speak about it only after questioning ${ }^{5}$.

The economic impact of fecal incontinence is huge. Not only the stay in a nursing home is expensive but also the incapability to work add to this. Though recent surgical devices are often criticized because of the high costs involved, conventional treatments are not inexpensive either. The total annual costs of diapers in the USA were estimated 400 million USD according to a study ${ }^{4}$ performed in 1988. In the Netherlands the costs of colostomy appliances were calculated 4400 USD per patient per year in $1998^{6}$. The costs of 63 patients with obstetric sphincter injuries exceeded 17000 USD (indexed 1996) per patient regardless of treatment or outcome ${ }^{7}$.

Patients who suffer from $\mathrm{FI}$ have a diminished quality of life largely due to anxiety, embarrassment, social isolation and inability to travel. The disease itself is not painful or physically incapacitating and therefore hardly noticed by either health professionals or the people in the patient's direct environment.

\section{Physiology}

There are a lot of factors involved in maintaining continence.

Next to an adequate mental function, the anal sphincters, a well-innervated pelvic floor, stool consistency and peristalsis are important factors. Diarrhea can lead to incontinence in almost any healthy subject. The same can happen with pseudo diarrhea in patients with fecal impaction. 
The sensation of the ano-rectum gives information about fecal volume and consistency. The rectum can distend and act as a reservoir up to the point where urgency can be felt.

The sphincter complex is built from an inner smooth muscle layer, the internal anal sphincter (IAS) and an outer striated, voluntary component, the external anal sphincter and puborectal muscles.

The internal anal sphincter (IAS) is a smooth muscle layer as a direct continuance of the muscularis propria of the rectum. It is innervated by the enteric nerve system and therefore not dependent on volition and capable of a long lasting tonic contraction. It is up to $80 \%$ responsible for the anal resting pressure. Like all circular muscles of the gut it will briefly relax distal of the point of distension. This can be measured as the recto anal inhibitory reflex (RAIR) and can be absent in Hirschsprung's disease. This reflex might play a part in the detection of stool consistency in the upper anal canal.

The external anal sphincter (EAS) together with the levator ani forms the striated muscle complex. The latter consists of the pubococcygeus, ileococcygeus and puborectalis muscle. The puborectalis muscle (PRM) passes the anorectum at the posterior side as a sling. Contraction or relaxation of this muscle changes the anorectal angle and is considered to be important for fecal continence 8 . The EAS and PRM are dependent on volition and are innervated by the pudendal nerve and pelvic branches of $\mathrm{S} 3$ and $\mathrm{S} 4$.

Arrival of stool in the rectum leads to progressive distension and relaxation of the IAS. As urge rises and defecation is wanted, relaxation of the PRM and EAS together with increase of the abdominal pressure, leads to evacuation of stool. As we know from ultrasound studies in women after vaginal delivery, the mere presence of a sphincter defect does not always lead to incontinence 9 . Probably there is some sort of compensation of this defect. Fecal incontinence is multifactorial in its etiology ${ }^{\text {io }}$.

\section{DIAGNOSIS}

Diagnostic tests in fecal incontinence are multiple. Of course history and good clinical examination are the basic tools in the work-up.

Anorectal manometry is a method for quantification of anal rest and squeeze pressure. Normal values are based on measurements in symptom free persons. However, low pressures do not necessarily reflect fecal incontinence and high 
pressures do not guarantee good continence. As a research tool in diagnosis and follow-up after treatment it can be helpful.

Testing of rectal sensation can be done with simple intra-rectal balloon insufflation. First sensation, urge volume and maximal tolerable volume as well as presence of the RAIR are easily detected, though not always reproducible. More reliable are barostat measurements.

Defecography is a barium radiology study not only to proof incontinence but also to reveal other evacuation disorders as prolapses, celes and pelvic floor dysfunction and provides a possibility of the measurement of the anorectal angle. This angle is believed to have an impact on continence, and correction of this angle was the aim in post anal repair ". Again, abnormalities revealed by this study do not correlate with the severity of incontinence.

For actual imaging of sphincter defects endo-anal ultrasonography is proven to be adequate and might correlate with anorectal manometry ${ }^{12}$. More recently MRI also offers a good visualization of the sphincter complex ${ }^{13}$.

Neurophysiology tests are meant to determine the innervation of the external anal sphincter and pelvic floor mostly by means of electromyography (EMG) of the anal sphincter by either a concentric needle or surface electrodes. Measurement of the pudendal nerve terminal motor latency (PNTML) can determine damage in the efferent pathway, but again prolonged latency times do not correspond with the severity of fecal incontinence. Recent publications even argue that PNTML has become obsolete ${ }^{10}$.

Endoscopy can be necessary to rule out concomitant inflammatory bowel disease (IBD) or neoplasms, especially in patients with anal blood loss or diarrhea.

The actual severity of the disease itself cannot be measured by objective tests. Therefore the most important factor in deciding for treatment will be the history of the patient, especially the impact on the quality of life. There are several scoring systems to objectivate this information. But even these scores don't reflect complete reality. Patients adlapt their lifestyles, do not go out anymore and stay at home, close to the toilet. The number of incontinence occurrences drops immediately.

\section{ETIOLOGY}

The cause of incontinence for feces can be congenital or acquired.

In the group of patients with congenital incontinence anal atresia (AA) is the 
most common cause. In this group fecal incontinence is frequently encountered in the high types of atresia where the total anus is missing and not merely ectopic. The treatment of choice in these patients is a reconstruction of the anorectum with the use of a pull through and subsequent reconstruction of the striated muscle complex, i.e. EAS and levator ani ${ }^{14}$.

The ability however to hold or expel feces is often troublesome in AA. As most patients find a way to deal with these problems, a part of them continues to have debilitating loss of feces.

Another congenital disorder consists of meningomyelocele and related disorders. These patients often lack neurogenic control over bowel and bladder. Constipation may also be part of their problems.

Acquired fecal incontinence is mostly due to sphincter damage either following delivery, direct trauma, infection or surgical trauma. Sphincter lesions are not uncommon, as was found with ultra sound in a group of women after delivery ${ }^{9}$. Neurogenic disorders are attributed to central neurological disorders, direct pudendal nerve injury or spinal lesions, due to trauma, vascular incidents, neoplasia or hernia nuclei pulposi.

Loss of rectal compliance due to proctitis or radiation leads to a diminished reservoir function and can cause urgency and an increase in frequency of defecation ${ }^{15}$.

In the elderly, fecal impaction is a frequent cause for $\mathrm{Fl}$ especially in institutionalized patients

Another group of patients develops incontinence in a later stage of life with an idiopathic etiology. These patients are mainly females over fifty. The majority had a hysterectomy in the past. In anorectal physiology testing they often show a prolonged pudendal nerve motor latency time ${ }^{16}$. Damage to the pudendal nerve is attributed to bulging of the pelvic floor during delivery or straining.

\section{Conservative treatment}

Diet alteration, the use of bulk agents and anti-diarrhea medication have some impact on fecal incontinence. It can be used as single therapy or as an adjunct to other therapies ${ }^{17}$. The best results have been recorded with loperamide, though it might be necessary to use the liquid formula to titrate the dose for the best result ${ }^{18}$. Biofeedback therapy is a behavioral therapy that trains a patient to be aware of a stimulus (rectal filling) and to subsequently use the EAS for closure of the anal canal. In order to do so, stimuli must be recognized and a response possible. The therapy might improve muscle contraction, rectal perception and coordination. Reports on success are very versatile in outcome, especially in the long-term 
follow up ${ }^{19}$. Though literature is abundant, true evidence for the benefit of biofeedback is still questionable ${ }^{20}$.

The use of enemas is also useful in the prevention of unwanted fecal leakage 21. This might regulate bowel movements according to the daily pattern and also lead to forced emptying of the rectosigmoid. This can be considered as a form of pseudo continence.

Anal plugs were designed to prevent F. It has been reported to work well in some patients, but was responsible for an uncomforting sensation and fecal urge in the majority of patients ${ }^{22}$.

The use of pads or diapers is not a treatment but an acceptance of fecal incontinence, offering a possibility to diminish the consequences. There is small evidence that disposable products are better than non-disposable ones ${ }^{23}$. Ironically, of all treatments for fecal incontinence, this has the highest grade of recommendation, evidence based medicine concerned.

\section{SURGICAL TREATMENT}

The final surgical therapy for fecal incontinence used to be the creation of a stoma. This leads to a disturbed body image ${ }^{24}$ and is not without complications ${ }^{25}$. The mean life-long costs of a colostomy are $\$ 71,576$ USD $^{6}$.

Another kind of stoma is the so-called antegrade colon enema (ACE), originally described by Malone, for children with constipation and incontinence ${ }^{26}$. Through a cecal access enemas can be given in a forward direction. A special colonic conduit was designed by Williams ${ }^{27}$ et al in order to treat constipation after dynamic graciloplasty (DCP).

A problem often seen after dynamic graciloplasty is obstructed defecation. Other techniques also encountered this problem. It is probably underreported as only a few studies mentioned obstructed defecation as a problem. Patients are not asked about this adverse event in general. It might even be regarded as 'super continent', because patients will report postponement of defecation for several hours. The studies that reported obstructed defecation are mentioned in table $7^{28-49}$. Overall reported disturbed evacuation for all surgical techniques, SNS excepted, is $25 \%$.

Sphincter lesions are suitable for anal repair with reasonable outcome ( 477 to $96 \%$ ), though concommitant pudendal nerve dysfunction has been mentioned as a contra indication for this therapy ${ }^{50,51}$ The success rate declines with a longer follow up ${ }^{28}$. Sphincter repair, if indicated, is still the first step in incontinence surgery today. 
Anal repair

\begin{tabular}{|c|c|c|c|c|}
\hline Author & Year & Nr of patients & $\begin{array}{l}\text { obstructed } \\
\text { defecation }\end{array}$ & percentage \\
\hline Malout & 2000 & 38 & 14 & 37 \\
\hline Yosbluoka & 1989 & 27 & 1 & 4 \\
\hline SLBTOTAL & & 65 & 15 & 23 \\
\hline
\end{tabular}

Postanal repair

Setti Carraro 1994

42

Total pelvic floor repair

Yoshioka

1999

$12-1$

Ciluteoplasty

\begin{tabular}{lllll}
\hline Devesa & 1997 & 17 & 3 & 18 \\
Yoshioka & 1999 & 12 & 0 & 0 \\
Madoff & 1999 & 11 & 1 & 9 \\
\hline SUBTOTAL & & 40 & 4 & 10 \\
\hline
\end{tabular}

Unstimulated graciloplasty

\begin{tabular}{lllll}
\hline Christiansen & 1990 & 13 & 1 & 8
\end{tabular}

Dynamic graciloplasty

\begin{tabular}{lcccc} 
Williams & 1991 & 32 & 4 & 13 \\
Korsgen & 1995 & 4 & 3 & 75 \\
Christiansen & 1998 & 13 & 3 & 23 \\
Mander & 1999 & 55 & 16 & 29 \\
Sielezneff & 1999 & 16 & 2 & 13 \\
Matzel & 2001 & 121 & 34 & 28 \\
Rongen & 2003 & 191 & 32 & 17 \\
\hline SUBTOTAL & & 383 & 84 & 22 \\
\hline
\end{tabular}

Artificial bowel sphincter

\begin{tabular}{lcccc}
\hline Cliristiansen & 1992 & 10 & 2 & 20 \\
Lehur & 1996 & 10 & 4 & 40 \\
Christiansen & 1999 & 17 & 2 & 12 \\
Savoye & 2000 & 12 & 6 & 50 \\
Lehur & 2000 & 20 & 9 & 45 \\
Wong & 2002 & 75 & 43 & 57 \\
Devesa & 2002 & 49 & 11 & 22 \\
Ortiz & 2002 & 22 & 2 & 9 \\
\hline SUBTOTAL & & 215 & 79 & 37 \\
\hline & & 770 & 196 & 25 \\
TOTAL & & & &
\end{tabular}

Table 1: Obstructed defecation atter surgery for fecal incontinence 
Dynamic graciloplasty is also used in total anorectal reconstruction (TAR) after abdominoperineal resection (APR) for rectal cancer. A perineal colostomy can be created, encircled by one or two stimulated gracilis muscles, acting as a closure mechanism. At first this was mostly done as a primary procedure partially combined with the APR ${ }^{59,60,63,64}$. A part of the patients with an APR might be able to cope with their colostomy, so direct TAR might not be essential in all of these patients.

\section{Artificial bowel sphincter (ABS)}

Instead of using autologous musculoplasties, prosthetic material can also be used in creating a neo-sphincter ${ }^{44,46}$. An inflatable cuff is placed around the anal canal and is kept filled by a pressure-regulating balloon. The patient can deflate the cuff by squeezing a pump placed in the labium or scrotum thus allowing defecation. Indication, costs and results are comparable to DGP, though morbidity is more severe, especially in the long run ${ }^{47}$. The procedure and follow-up are probably less demanding for the surgeon. A recent review argues that the procedure is too experimental to be done outside research hospitals ${ }^{65}$. However, unlike DGP, the ABS has a FDA approval.

\section{Sacral nerve stimulation (SNS)}

Originally developed for urinary incontinence, a side effect of electrical stimulation of the sacral roots of S3 and S4 on fecal incontinence was noticed. The pioneer of this technique for fecal incontinence was Matzel ${ }^{66}$, soon to be followed by others ${ }^{67-69}$. Prerequisite for this therapy is an intact sphincter, though anal repair can be used to restore the anatomy, without gross neurological failure. Though the actual mechanism is yet unknown, chronic electrical stimulation leads to a modulation of the sacral nerves. A percutaneous temporarily testing can be performed and the results can be used in the decision to proceed with the implantation of permanent equipment for SNS. This procedure is minimally invasive and has low morbidity ${ }^{70}$. Contrary to DGP 71 and ABS ${ }^{47}$ which can only successfully be performed in experienced medical centers, SNS gives also good results in clinics with ample experience ${ }^{72}$.

\section{OUTLINE OF THIS THESIS}

Outcome and adverse events in dynamic graciloplasty have only been described in small groups or in groups with short follow up. Long-term results and a large group of patients were needed to determine the efficacy of the procedure. It is known that the procedure has a steep learning curve ${ }^{71}$ and 
some colleagues abandoned DGP because of this. It was uncertain whether our results would improve in time.

In earlier reports longevity of the IPG was estimated for costs analysis 6 but true data were still lacking.

These questions were the reason to analyse our prospectively collected data in 200 patients with a median follow up of 261 weeks. (Chapter 2).

In our initial experience the procedure was performed in two stages. In the first stage the graciliswrap around the anal canal was made and in a second stage the electrodes and IPG were implanted. It was thought that not combining a contaminated perianal operation with implantation of body-foreign material could prevent infectious complications. The question whether a one-stage procedure can be as safe as a two-stage procedure has led to a matched control study (chapter 3 ).

In dynamic graciloplasty there are two different ways of placing electrodes, either with the use of an epineural ${ }^{35}$, or an intramuscular ${ }^{73}$ located electrode. With epineural electrodes one might expect a more efficient stimulation, as all the muscle fibers will contract at a probably low stimulation voltage. However, exploration of this nerve and anchoring the electrodes might create morbidity. The results and complications of epineural versus intramuscular electrodes for dynamic graciloplasty were compared in co-operation with Williams et al (chapter 4).

Total anorectal reconstruction after APR with the use of dynamic graciloplasty, was initially performed in one session. The question was raised if it was possible to perform this procedure secondarily in patients who could not cope with their colostomy. It would be much better to select patients, who could really benefit. from TAR in terms of motivation and stoma problems and who have proven to be oncologically safe. This was the aim of a prospective study (chapter 5).

Patients with implanted metal material are banned from magnetic resonance imaging (MRI). Fear for migration of the implant as well as heat development play an important role in this absolute contraindication. With recent developments in this field of radiology ${ }^{74}$ it is sometimes very desirable to use these investigations especially in colorectal surgery. An in vitro study was developed to determine whether MRI could be performed safely in patients with dynamic graciloplasty (chapter 6).

Unfortunately a substantial part of patients suffers from obstructed defecation following surgical treatment for fecal incontinence. Some of the patients with 
impaired evacuation after dynamic graciloplasty appeared to have slow transit constipation, a condition that was not observed during their period of incontinence. We looked at the outcome of a minimally invasive procedure for antegrade irrigation in patients with slow transit constipation in a prospective study (chapter 7). 


\section{References}

1. Nelson, R., et al., Community-based prevalence of anal inconthence /ama, 1995. $274(7)$ : p. 559-61.

2. Talley, NJ, et al., Prevalence of gastrointestinal symptoms in the elderly: a populationbased study. Gastroenterology, 1992, 102(3): p. 895-901.

3. Roberts, R.O., ef al., Prevalence of combined tecal and urinary incontinence: a communily-based study. I Am Ceratr Soc, 1999. 47(7): p. 837-41.

4. Lahr, $\mathrm{C}$, Evaluation and treatment of incontinence. Practical Castroenterd, 1988. 12: p. $27-35$

5. Kalantar, IS., S. Howell, and N.J. Talley, Prevalence of taecal incontinence and associated risk factors; an underdiagnosed problem in the Australian cominunity? Med f Aust, $2002.176(2):$ p. 54-7.

6. Adang. E.M., et al., Costeffectiveness of dynamic graciloplasty in patients with fecal incontinence. Dis Colon Rectum, 1998. 41(6): p. 725-33; discussion 733-4.

7. Mellgren, A., et al., Longterm cost of fecal inconthence secondary to obstenic injuries. Dis Colon Recum, 1999. 42(7): p. 857-65; discussion 865-7.

8. Fernandez-Fraga, X., F. Azpiroz, and J.R. Malagelada, Significance of pelvic floor muscles in anal incontinence. Castroenterology, 2002, 123(5): p. 1441-50.

9. Burnett, 5 ., et. al., Unsuspected sphincter damage following childbirth revealed by anal endosonography. Br / Radiol, 1991. 64: p. 225-7.

10. Bharucha, A.E, Outcome measures for fecal incontinence: anorectal structure and function. Gastroenterology, 2004. $126(1$ Suppl 1): p. 590-8.

11. Parks, A. Anorectal incontinence. Proc. R. Soc. Med., 1975. 68: p. 681-90.

12. Falk, P.M. et al., Transanal ultrasound and manometry in the evaluation of fecal incontinence. Dis Colon Rectum, 1994. 37(5): p. 468-72.

13. Beets-Tan, R.G. et al. Measurement of anal sphincter muscles. endoanal US, endoamal MR inaging, or phased-array MR imaging? A study with healthy wolunteers. Radiology, 2001.220(1): P. $81-9$.

14. devries, P. and A. Pena, Posterior sagittal anorectoplasty. / Pediat Surg, 1982, 17: p. 638-43.

15. Rao, S.5, et al. Anorectal sensitivity and responses to rectal distention in patients with ulcerative colitis. Gastroenterology, 1987, 93(6): p. 1270-5.

16. Kiff. E. and M. Swash, Slowed conduction in the pudendal nerves in ideopathic (neurogenic) faecal incontinence. BH J Surg, $1984,71:$ p. 614-6.

17. Buie, W. Nonoperative medical management of fecal incontinence. Sem col hact surg. 1997. 8(2): p. $73-9$.

18. Scarleti, Y., Medical management of fecal incontinence. Gastroenterology, 2004. $126(1$ Suppl 11: p. 555-63. 
19. Marcello, $p$ and 1. Coller, Neuromuscular reducation and the management of lecal incontinence. Sem col rect surg. 1997. 82): p. 34-92.

20. Norton $\mathrm{C}, \mathrm{H}, \mathrm{G}$. Brazzell M. Bioledback and/or sphincter exercises for the treatment of farcal incontinence in adults (Cochrane Review), in The Cochrane Library. 2004. John Willey Sons, Lid.: Chichester, UK.

21. Briel, I.W. ef al., Clinical value of colonic irrigation in patients with continence disturbances. Dis Colon Rectum, 1997. 4077): p. 802-5.

22. Norton, C. and M.A. Kamm, Anal plug for faecal incontinence. Colorectal Dis, 2001. $3(5): p .323-7$.

23. Brazzelli M. S.E., Vale L, Absorbent products for containing urinary andior faecal incontinence in adults (Cochrane Review), in The Cochrame Library 2004, John Wiley \& Sons, Ltel: Chichester, UK

24. Orbach, $C$. and $N$. Tallent, Modilication of perceived body and of body concepts. Arch Gen Psychiatry, 1965. 12: p. 126-135.

25. Londono-Shimmer, E.E., A.P. Leong, and R.K. Phillips, Life table analysis of stomal complications following colostomy. Dis. Colon Rectum, 1994. 37: p. 916-920.

26. Malone, P.S., P.G. Ransley, and E.M. Kiely, Preliminary report: the antegrade continence enema. Lancet, 1990. 33618725): p. 1217-1218.

27. Williams, N.S., S.F. Hughes, and B. Stuchfield, Continent colonic conduit for rectal evacuation in severe constipation. Lancet, 1994. 343(8909): p. 1321-1324.

28. Malouf, A.l. et al., Long-term results of overlapping anterior anal-sphincter repair for obstetric trama. Lancet, 2000. 355(9200): p. 260-5.

29. Yoshioka, K. and M.R. Keighley, Sphincter repair for fecal incontinence. Dis Colon Recum, $1989.32(1)$ : p. 3942 .

30. Setti Cararo, P. M.A. Kamm, and R.I. Nicholls, Long-term results of postanal repair for neurogenic faecal incontinence. Br / Surg, 1994. 81(1): p. 140 4.

31. Voshioka, K. OA. Ogunbiyi, and M.R. Keighley, A pilot study of total pelvic lloor repain or gluteus maximus transposition for postobstetric neuropathic fecal incontinence. Dis Colon Rectum, 1999. 42(2): p. 252.7.

32. Devesa, J.M, et al. Bilateral gluteoplasty for fecal incontinence. Dis Colon Rectum, 1997. 4018: p. $883-8$.

33. Madoff, R.D., et al. Safety and efficacy of dynamic muscle plasty ror anal incontinence: lessons from a prospective, multicenter trial. Gastroenterology, 1999. 116 (3) p. 549-56.

34. Christiansen, 1., M. Sorensen, and O.O. Rasmussen, Gracilis muscle transposition for faccal incontinence. Br/ Surg, 1990.77(9): p. 1039-40.

35. Williams, N.S., et al, Development of an electrically stimulated neoanal sphincter. Latmet, 1991, 33868776): p. $1166-9$

36. Korsgen, S. and M.R. Keighley Stimulated gracilis neosphincter-not as good as previously thought. Report of four cases. Dis Colon Rectum, 1995. 38(12): p. 1331-3. 
37. Christiansen, 1., O.O. Rasmussen, and K. Lindortf-Larsen, Dynamic graciloplasty for severe anal incontinence. Br/ Surg, 1998. $85(1)$ : p. 88.91 .

38. Mander, B.J., ef al., Preliminary results of a multicentre triall of the electrically stimulated gracilis neoand sphincter. $\mathrm{Br} / \mathrm{Surg}, 1999.86(12)$ : p. 1543-8.

39. Sielezneff, 1., et al., Dynamic graciloplasty in the treatment of patients with laecal incontinence. Br J Surg, 1999. 86(1): p. $61-5$.

40. Matzel, K.E., et al., Complications of dynamic graciloplasty: incidence, management. and impact on outcome. Drs Colon Rectum, $2001,44(10)$ : $0.1427-35$.

41. Rongen, M.J., et al., Long-term follow-up of dynamic graciloplasty for fecal incontinence. Dis Colon Rectum, 2003. 46(6): p. 716-21.

42. Christiansen, J. and B. Sparso, Treatment of anal incontinence by an implantable prosthetic anal sphincter. Am Surg. 1992. 215(4): p. 383-6.

43. Lehur, P.A., et al., Results of artificial sphincter in severe anal incontinence. Report of 14 consecutive implantations. Dis Colon Rectum, 1996. 39(12): p. 1352-5.

44. Christiansen, 1., O.O. Rasmussen, and K. Lindorff-Larsen, Long-term results of antificial anal sphincter implantation for severe anal incontinence. Ann Surg, 1999. 230(1): p. 45-8.

45. Savoye, G., et al., Manometric assessment of an artificial bowel sphincter. Br i Surg. 2000, 87(5): p. 586-9.

46. Lehur, P.A., J.V. Roig, and M. Duinslaeger; Artificial anal sphincter: prospective clinical and manometric evaluation. Dis Colon Rectum, 2000. 43(8): p. 1100-6.

47. Wong, W.D. et al. The safety and efficacy of the artificial bowel sphincter for fecal incontinence: results from a multicenter cohort study. Dis Colon Rectum, 2002. 45(9): p. $1139-53$.

48. Devesa, I.M., et al., Artificial anal sphincter: complications and functional results of a large peirsonal series. Dis Colon Recum, 2002. 45(9): p. 1154.63.

49. Otiz, H. el al., Complications and functional outcone following artificial anal sphincter indantation. Br/ Surg, 2002. $89(7): p .87741$.

50. Fang, D.T., et al. Overapping sphincteroplasty for acquired anal incontinence. Dis.Colon Rectum, 1984. 27111 1: p. 720.722.

51. Laurberg, S., M. Swash, and M.M. Henry, Delayed extermal sphincler repaur for obstetric tear. Br. Surg. 1988. $75(8)$ p. p. $786-788$.

52. Devesa, I.M., et al., Total fecal incontinence--a new method of gluteus maximus transposition: preliminary results and report of previous experience with similar procedures. Dis. Colon Rectum, 1992. 35(4): 2. 339-349.

53. Christiansen, J., C.R. Hansen, and O. Rasmussen, Bilateral gluteus maximus transposition for anal incontinence. Br J Surg, 1995. 82(7): p. 903-5.

54. Pickrell, K.l., et al., Construction of a rectal sphincter and restoration of continence by transplanting the gracilis muscle. Ann.5urg., 1952. 135(6): p. 853-862. 
55. Corman, ML., Follow up evaluation of gracilis muscle transposition for fecal incontinence. Dis. Colon Rectum, $1980.23:$ p. $552-555$.

56. Konsten, 1. et al., Morphology of dynamic graciloplasty compared with the anal sphincter. Dis Colon Rectum, 1993. 36(6): p. 559-63.

57. Ceorge, B.D., at. Physiological and histochemical adaptation of the electrically stimulated gracilis muscle to neoanal sphincter function. Br.J.5urg., 1993. 80 10): p. $1342-1346$.

58. Baeten, C., F. Spaans, and A. Fluks, An implanted neuromuscular stimulator for fecal continence following previously implanted gracilis muscle. Report of a case. Dis. Colon Rectum, $1980.31(2)$ : p. 1344137.

59. Cavina, E. et al., Construction of a continent perineal colostomy by using electrostimulated gracilis nuscles after abdominoperineal resection: personal technique and experience with 32 cases. Jal. $5 \mathrm{urg} .5 \mathrm{ci}$. 1987. 17(4): p. 305-314.

60. Milliams, N.S., el al. Construction of a neorectum and neoanal sphincter following previous proctocolectomy. Br. $1.5 \mathrm{ug}, 1989.76111 \% \mathrm{p} .1191-1194$.

61. Baten, C.C., et al.. Anal dynamic graciloplasty in the treatment of intractable fecal uncontinence. N Engl/ Med, 1995. 332(24): p. 1600-5.

62. Seccia, $M_{\text {. }}$, ell al. Study protocols and functional results in 86 electrostimulated graciloplasties. Dis Colon Rectum, 1994. 37(9): p. 897-904.

63. Geerdes, B.P. et all. Total anorectal reconstruction with a double dynamic graciloplasty after abdominoperineal reconstruction for low rectal cancer. Dis Colon Rectum, 1997. $40(6)$ : p. $698-705$.

64. Cavina, E. et al., Perineal colostomy and electrosimulated gracilis "neosphincter" after abdomino-perineal resection of the colon and anorectum: a surgical experience and follow-up study in 47 cases. Int. Colorectal Dis., 1990. 5: p. 6-11.

65. Mundy, $L_{*}$ at al. Systematic rewiew of safety and eflectiveness of an artificial bowel sphincter for facal incontinence. Br / Surg, 2004 91 (6): p. 665-72.

66. Matzel, K.E, el al., Permanent electrostimulation of sacral spinal nenves with an implantable neurostimulator in treatment of fecal incontinence. Chirurg. 1995. 66(8): p. 813-7.

67. Vaizey, C. ., et al., Double blind crossover study of sacral nerve stimulation for fecal incontinence. Dis Colon Rectum, 2000. 43(3): p. 298-302.

68. Ganio, E., at al. Shortferm sacral nerve stimulation for functional anorectal and urinary disturbances: results in 40 patients: evaluation of a new option for anorectal functional disorders. Dis Colon Rectum, 2001. 44(9): p. 1261-7.

69. Uludag, O. et al. Sacral neuromodulation is effective in the treatment of fecal incontinence with intact sphincter muscles; a prospective study. Ned Thidschr Ceneeskd, 2002, 146(21): p. 989-93.

70. Kenefick, NJ and I. Christiansen, A review of sacral nerve stimulation for the treatment of faecal incontinence. Colorectal Dis, 2004, 6(2): p. 75-80. 
71. Baeten, C.G., et al. Safety and efficacy of dyamic gracioplasty for facal incontinence: report of a prospective, multicenter trial. Dynamic Graciloplasty Therapy study Group. Dis Colon Rectum, 2000. 43(6): p. $743-51$.

72. Matzel, K.E. el al., Sacral spinal nerve stimulation for faecal incontinence: mullicentre study. Lancet, 2004, 363(9417): p. 1270-6.

73. Baeten, C.G., et al., Dynamic graciloplasty for treatment of hecal incontinence. Lancest. $1991.338(8776 \%$ : p. 1163-5.

74. Beets-Tan, R.G., et al., High-resolution magnetic resonance imaging of the anorectal region without an endocoil. Abdom Imaging 1999, 24(6): p. 576-81; discussion 582 4.

75. Saunders, J.R., A.J. Eccersley, and N.S. Williams, Use of a continent colonic conduit for treatment of refractory evacuatory disorder following construction of an electrically stimulated gracilis neoanal sphincter. Br / Surg, 2003. 90(11): p. 1416-21.

76. Saunders, J.R., N.S. Williams, and A.J. Eccersley. The combination of electrically stimulated gracilis neoanal sphincter and continent colonic conduit: a step forward for total anorectal reconstruction? Dis Colon Rectum, 2004, 47(3): p. 354-63; discussion $363-6$. 
$<+e^{\prime}$ 
Mart-Jan GM Rongen MD

Özenç Uludag MD

Kadri El Naggar MD +
Bas P Geerdes MD PhD

Joop Konsten MD, PhD

Cor GMI Baeten MD, PhD

\section{Long-term Follow-up of Dynamic Graciloplasty for Fecal Incontinence}

From the Department of Surgery, University Hospital Maastricht, Maastricht, the Netherlands

+ Deceased December 1999

Read at the meeting of The American Society of Colon and Rectal

Surgeons, San Diego, California, June 2 to 7,2001

Dis Colon Rectum, 2003. 46(6): p. 716-21 


\section{ABSTRACT}

Purpose. Graciloplasty has been used as a treatment for end-stage fecal Incontinence since 1946. Electrical stimulation with an implantable pulse generator has existed for 15 years. The gracilis muscle is wrapped around the anat canal and stimulated by intramuscular electrodes connected with an IPG. Initial reports have been promising but long term results have not been presented to date.

Methods: Data of 200 consecutive patients with a follow up of at least two years were analyzed in a prospective manner from 1986 till 1999.

Resuls the overall success rate was 72 percent. In patients with fecal incontinence caused by trauma the rafe was 82 percent. Once continent, patients remained continent after a median follow up of 261 (standard deviation 132) weels. Median IPC survival untill battery expiration was 405 weeks. Pisturbed evacuation remained a problem in $16 \%$ of all patients. Complications Were frequent but tieatable.

Conctusion. Dynanic graciloplasty is a good, costeffective treatment for fecal inconlinence with results lasting for a median of more than five years. 


\section{INTRODUCTION}

Since 1986 dynamic graciloplasties (DGP) have been performed for end-stage fecal incontinence ${ }^{58}$. Many reports were written about the outcome and pitfalls this procedure and its many variations ${ }^{2-6}$. Results were maintained for most of the groups involved in this technique, but long-term efficacy has not been reported yet, certainly not for a great number of patients. Discrepancies between functional and clinical results in some patients also emphasize the need for a closer look at the overall results.

\section{METHODS}

\section{Work-up}

Preoperative workup of these patients, in addition to thorough history and physical examination, consists of anal manometry, defecography and electromyography. The degree of incontinence was recorded according to the method of Williams and colleagues ${ }^{35}$. A score of 1 indicates continence with respect to flatus, liquid and solid stool; a score of 2 means incontinent to flatus only; and a score of 3 includes occasional incontinence for liquid stool. Scores of 4 and 5 refer to occasional and frequent loss of solid stool, respectively. Scores of 1 and 2 were considered to indicate successful results.

\section{Procedure}

After receiving prophylactic 24-hour antibiotics administration, the patient was placed in the lithotomy position with moveable stirrups. An incision was made in the medial side of the upper leg to free the gracilis muscle and ligate the peripheral arteries. This can be done without concern of damaging the vascularization?. Just below the knee, the tendon had to be detached from its insertion. By dissecting the muscle proximally, the neurovascular bundle was identified and preserved.

After creation of a circular tunnel around the anus and a subcutaneous connection to the leg, the muscle was wrapped around the anus loosely, and the tendon was anchored to the ramus inferior of the pubic bone. Wraps can be made in three different fashions. The first turn can be made anterior or posterior of the anal canal with contralateral tendon attachment (gamma or epsilon

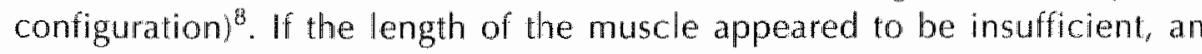
ipsilateral attachment was made (alpha configuration).

The second stage of the operation was the implantation of the leads and pulse 
generator (IPG) (Itrel II, model 7424 or INTERSTIMQ, model 3023, Medtronic, Kerkrade, the Netherlands). The intra-muscular electrodes (model SP 5566 or 4300 35. Medtronic, Kerkrade, the Netherlands) were positioned close to the nerve and subsequently connected to the pulse generator. The IPG was placed beneath the rectus fascia in the lower abdomen and the electrodes were tunneled subcutaneously. None of the patients received a protective stoma. When patients had already had a colostomy, the stoma was temporarily left in place. An electric training protocol was used to change the gracilis muscle from an easy fatigable type of muscle to one that is capable of sustained contraction ${ }^{56}$. Telemetry (Programmer console model 7432 , Medtronic, Kerkrade, the Netherlands) was used to adjust stimulation amplitude to achieve an increase in anal pressure of at least 20 $\mathrm{mmHg}$ during training.

By using a magnet or hand-held programmer, patients are able to control the IPG, and subsequently, relaxation or contraction of the neosphincter allows defecation. Efficacy was evaluated after completion of the training at each patient visit. Adjustment of the amplitude was performed if indicated by anal manometry. The latter was performed with a sollid-state catheter (Koningsberg Instruments, Pasadena, Calif. USA) connected to a computer-assisted polygraph (Synectics Medical, Stockholm, Sweden)). Williams' continence score (scores of 1 and 2 were considered as continent), stool frequency, postponement of defecation, involuntary loss of feces and adverse events were recorded at every out patient visit, at least once per year. Median IPG survival, meaning the time needed for battery depletion and subsequent IPG renewal, was calculated according the Kaplan-Meier method. Data were collected in a prospective manner.

\section{Patients}

Since November 1986, 200 patients ( 47 males) were operated on with a followup of at least two years. Mean age at operation was 48 (range, 15-77) years. One hundred ninety-one patients were evaluable; nine were lost to follow-up or waiting for stoma reversal. The patients were divided into four groups, based on cause of fecal incontinence. (Tab/e 1)

Twenty-eight patients had anorectal malformations at birth. Ninety-eight patients had direct sphincter-trauma caused by delivery, accident, infection or surgery. Fifty-eight patients had moderate to severe pudendopathy or so-called idiopathic incontinence, and sixteen patients had neurological disorders, ranging from meningomyelocele to hernia nuclei pulposus and direct spinal lesions.

Previous anal surgery had been performed in 130 cases, primarily anal repairs 
$(n=73)$ and postanal repairs $(n=38)$. Biofeedback therapy had been given in 86 cases as a treatment for fecal incontinence. Twenty-seven patients already had a colostomy at the time of the DGP.

\begin{tabular}{l|cc|} 
& Patients (n) & Success rate(\%) \\
\hline Congenital & 28 & 52 \\
Trauma & 98 & 82 \\
Idiopathic & 58 & 72 \\
Neurologic & 16 & 80 \\
\hline Total & 200 & 72 \\
\hline
\end{tabular}

Table 1: Success rate categorized by cause of focal incontinence

\section{RESULTS}

After a median follow-up of 261 weeks, 145 of 200 patients scored a continence grade 1 or 2 on the Williams scale (continent for all contents or incontinent to flatus only), giving a overall 72 percent success rate (95percent confidence interval 66-78 percent). Nine patients were not evaluable, seven of whom were lost to follow-up. The other two were ostomates because of perineal infections not related to the procedure.

The success rates in the four groups based on origin of incontinence showed a lower success rate in anal atresia patients (Table 1). No significantly different success rates were found for any wrap configuration or with regards to volumes of first sensation and urge at balloon insufflation.

Of the 46 failures, 32 patients were not continent despite a functional DGP. Untreatable diarrhea was the reason for persisting incontinence in 17 patients. In the remaining 15 cases no reason for failure could be found.

In 14 cases, technical problems and complications were responsible for failure. Infection was the cause in five patients, and in five cases there was no measurable contraction. The rectum was perforated by the tendon of the gracilis muscle, leading to a colostomy in one patient with impaired sensation of the perineal region. In three patients stimulation resulted in pain despite improvement of continence in two of these patients.

As was expected, this procedure had a learning curve (Fig. 1). Figure 1 also shows that technically, the procedure is nowadays almost always successful, though it does not lead to restoration of continence in all cases. 


\section{REASON FOR FAILURE IN TIME}

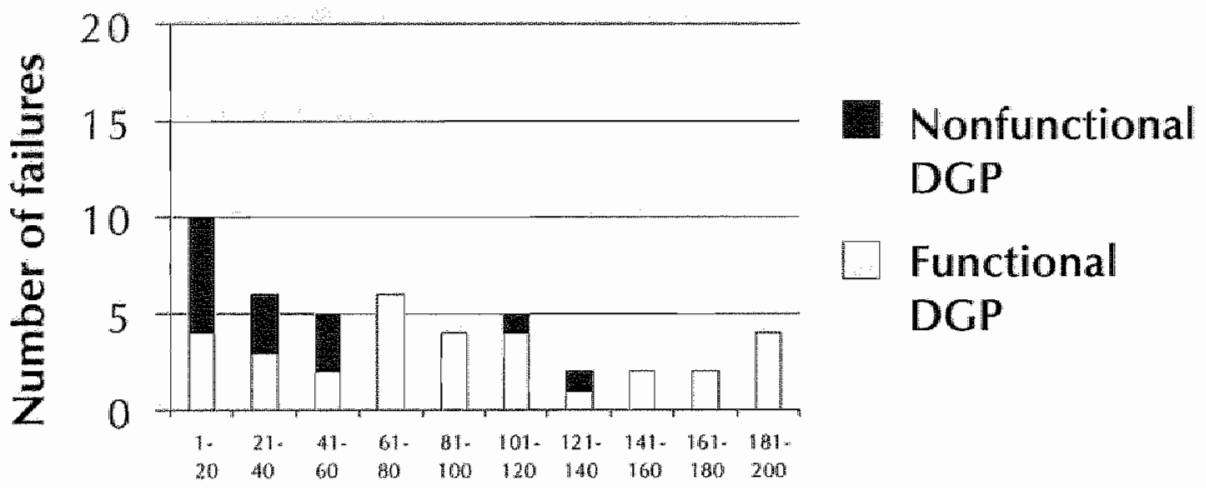

Patient number

Figure 1: Failures in dyramic graciloplasty (DCP) chronologically per 20 patients.

\section{COMPLICATIONS}

There were 138 complications (Table 2) with no mortality. Pain caused by stimulation could be solved primarily by reprogramming stimulation parameters, although it led to permanent failure in three cases.

Infections ( $n=24)$, leading to explantation of the $I P G$, were frequent in the first 20 patients ( 8 times, with 3 subsequent infections in one patient). The incidence of sepsis decreased through changes in antibiotic regimen and use of topical antibiotics. In the last 100 patients six infections occurred, five within one month after implant and one after reintervention (lead revision). Bacteriologic examination always showed skin flora as the source of infection

IPG displacement was seen in 12 patients who had a subcutaneous pocket but no further cases of displacement have been seen, because after the initial 65 patients the device has been placed underneath the rectus fascia.

Failure of contraction with stimulation can be caused by two factors. Either the wrap is not able to give compression, or stimulation is not optimal. By asking the patient to contract the graciloplasty voluntarily (this is done by endorotating and flexing the knee) a distinction was possible. If voluntary contraction appeared to be insufficient, tightening of the wrap was possible or a new graciloplasty 


\begin{tabular}{lcc} 
Complications & \\
\hline DISTURBED EVACUATION & 32 & 16 \\
INFFCION & 24 & 12 \\
PAIN CAUSED BY STIMULATION & 16 & 8 \\
PG DISPLACEMENI & 12 & 6 \\
RECTAL PERFORATION & 10 & 5 \\
FAILURE OF CONTRACTION WITH STIMULATION & 9 & 4.5 \\
LEAD PROBLIEMS & 6 & 3 \\
PERINEAL PAIN & 6 & 3 \\
URINARY RETENTION & 5 & 2.5 \\
WOUND ABSCESS, LEG & 5 & 2.5 \\
OTHER & 13 & 6.5 \\
\hline
\end{tabular}

$\mathrm{PC}=$ inplantabie pilse generator

$N=138$ total complications

Table 2

could be performed from the contralateral side. Lead replacement led to better contraction in all other cases, which suggests that fibrosis around the lead or dislocation of the electrode could cause its malfunction. Lead revision led to functional graciloplasty in five of six cases.

A new graciloplasty was performed in seven cases, resulting in six functional graciloplasties (with only 2 continent).

Perforation of the anorectum occurred ten times, leading to failure and permanent colostomy in one patient with absent pelvic sensation. This perforation was caused by erosion of the tendon during stimulation. The remaining cases were the result of a self-inflicted injury, balloon perforation at biofeedback therapy, and seven intraoperative perforations. In four cases diverting stomas were not necessary; two other patients had already had colostomies. Ultimately, seven of the ten had a successful outcome. Perineal pain was resolved by perineall exploration with periostal suture removal or culting of the gracilis tendon at the attachment to the periost.:

\section{Disturbed evacuation}

Initial evacuation disorders are not uncommon after DCP but disappear within a few months without any treatment. Thirty-two patients were left with chronic evacuation problems. Of these 32 patients, 3 had a remaining combination of incontinence and constipation. Five cases were attributed to a narrow graciloplasty, with anal resting pressures of 102 and $108 \mathrm{mmH}$ in two cases at last follow up. 


\section{Survival function of first IPG}

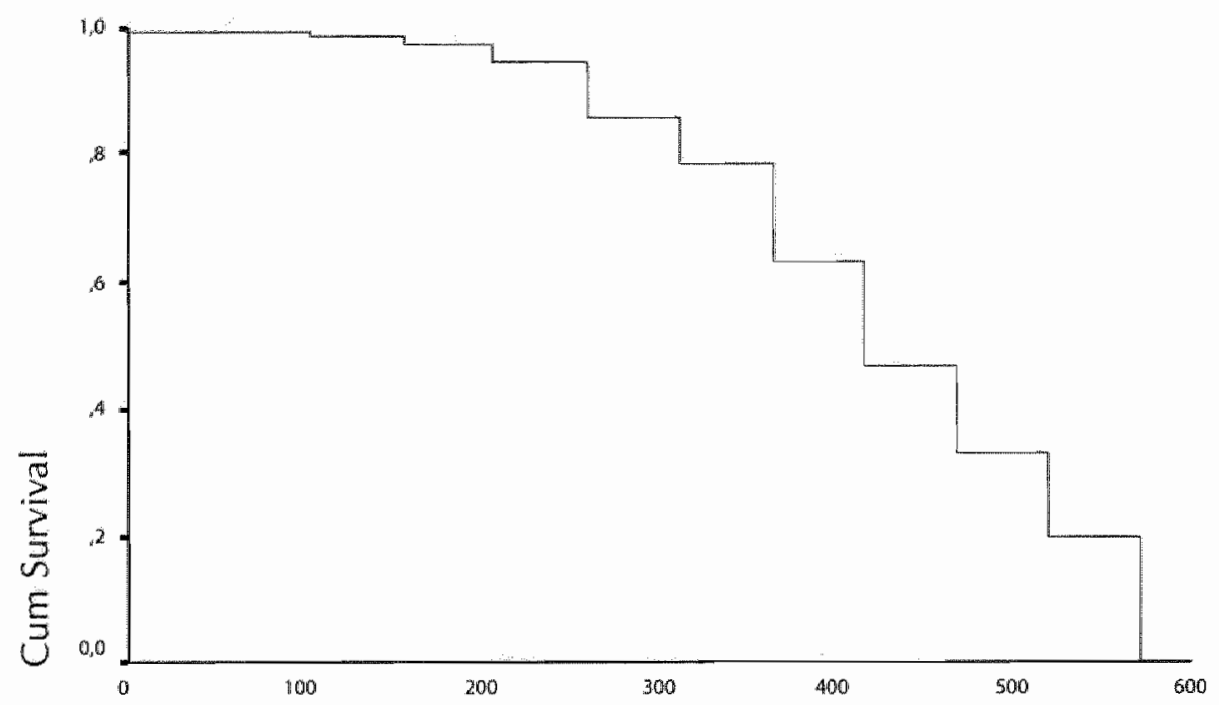

Times in weeks

Figure 2: Cumulative survival of the implantable pulse generator (IPC).

The other 24 patients had a mean anal resting pressure at the end of the training period of 56 (standard deviation $+15,6) \mathrm{m} m \mathrm{H} H \mathrm{~g}$ compared to 62 (standard deviation $+19,6) \mathrm{mm} \mathrm{Hg}$ for the total group and none had any abnormal findings at rectal examination or defecography. Anal sensitivity and capacity were not different from the rest of the patients, nor was there a difference in the distribution of causes of the incontinence. In two patients, a prolonged transit time of the colon was measured. One was given ileocecal access for antegrade enemas, and the other was given an ileostomy; both had resolution of the problem.

Pulse generator life

Median survival of the IPG was 405 weeks (Fig. 2) before battery depletion. Changing of the IPG was successful in all cases without complications. 


\section{DISCUSSION}

The success rate of DGP after a median of five years was 72 percent, which is better than the long-term results of anal repair ${ }^{28}$. Although DGP was technically functional in 91 percent of the cases, the presence of a (neo) sphincter is only partially responsible for continence.

Insufficient forming of stool led to leakage in 17 patients. The lower success rates in the congenital and pudendopathy group give support to the conclusion that beside sphincter function one of the factors sensation, distension, evacuation, anocortical integration or stool consistency might be impaired in these groups. It is however remarkable that the lower motor neuron lesion group, which also had diminished sensation and evacuation problems, were better off in terms of success.

One might argue that presently, patients' diaries are considered the best way to determine continence. At the start of the present study this technique was not incorporated in the data collection, except in a small $(n=15)$ subset of patients as part of a multicenter study. Morbidities associated with this procedure are numerous in frequency but generally manageable without major interventions. Disturbed evacuation was primarily a temporary problem, and when this problem remained, diet advice and bulk laxatives resolved the problem. In some patients, biofeedback therapy led to resolution of the problems. The observation that initial evacuation difficulty frequently was present might be explained by the fact that during their years of incontinence, there was no evacuation mechanism active in these patients.

Infections were initially a major problem but diminished significantly after a change in infection prevention. Even if an infection occurs, with subsequent removal, implantation can be done repeatedly provided the gracillis muscle is vital and produces a voluntary contraction.

Anal perforation is a problem that might be prevented by use of a vaginal incision during the preparation of the perianal tunnel in patients with extensive scarring in the perineum anterior of the anus. Care must be taken during preparation that the tendon is not sutured too tightly around the anal canal to prevent it eroding through the anus.

Because the IPG life is a median of 7.8 years, cost-effectiveness of the therapy appears to be better than calculated previously ${ }^{6}$.

Recent multicenter studies show lower success rates, high morbidity and even mortality ${ }^{33,71}$. However, many of these centers had little experience in the procedure and a relatively small number of patients enrolled in these studies. Given the learning curve of this procedure (shown in Fig. 1) these results can 
be explained. Other studies from more experienced centers show results comparable to those of the present study ${ }^{13,14}$.

In the treatment of intractable fecal incontinence sacral nerve stimulation ${ }^{66,67}$ is a promising new therapy. Patients with gross sphincter defects are not likely to benefit from this treatment and will continue to depend on the creation of neosphincters. A recently presented multicenter study on the artificial bowel sphincter ${ }^{47}$ does not show better success rates and morbidity than achieved with DGP.

An accurate predictor of successful outcome remains to be found. To date, neither sensation, capacity nor any other preoperative investigation has provided a clear prospect of outcome in individual cases. The present study emphasizes that incontinence is not just a mechanical problem. With the development of sacral nerve modulation and the ability to evaluate the effect of modulation, patients with incontinence who do not respond to this treatment will be selected. This group might be better candidates for DGP, with an increased chance of success. Regardless, DGP cleared the road for sacral nerve modulation, because we have gained experience with implanted electrical devices for fecal incontinence.

\section{ACKNOWLEDGEMENTS}

In memory of Kadri El Naggar 


\section{REFERENCES}

1. Baeten C. Spaans F, Fluks A. An implanted neuromuscular stimulator for fecal continence following previously implanted gracilis muscle. Repont of a case. Dis.Colon Rectum 1988; 31(2):134-137.

2. Williams NS, Patel ], George BD, Hatlan RI, Watkins ES. Development of an electrically stimulated neoanal sphincter. Lancet 1991;33818776):11669.

3. Seccia M, Menconi C, Balestri R, Cavina E. Study protocols and functional results in 86 electrostimulated graciloplasties. Dis.Colon Rectum 1994;37(9):897-904.

4. Baten CG, Konsten 1. Spans F, et al. Dynamic graciloplasty for treatment of laecal incontinence. Lancet 1991,338(8776):1163-11165.

5. Baeten $C G$, Geerdes BP, Adang $E M$, et al. Anal dynamic graciloplasty in the treament of intractable fecal incontinence. N.Engl/.Med. 1995;332(24):1600-1605.

6. Madoff RD, Rosen HR, Baeten $\mathrm{CC}$, et al. Safety and efficacy of dynamic muscle plasty for anal incontinence: lessons from a prospective, multicenter trial. Castroenterology $1999 ; 116(3): 549-56$

7. Geerdes BP, Kurvers HA, Konsten I, Heineman E, Baeten CG. Assessment of ischaemia of the distal part of the gracilis muscle during transposilion for anal dynamic graciloplasty. Br / Surg 1997;84(8):1127-9.

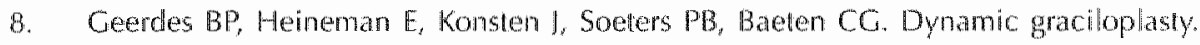
Complications and management. Dis Colon Rectum 199639(8):912-7.

9. Konsten 1, Baeten CG, Havenith $\mathrm{MG}_{i}$ Soeters PB. Morphology of dynamic graciloplasty compared with the anal sphincter. Dis Colon Rectum 1993;36161:559-63.

10. Malouf A), Norton CS, Engel AF, Nicholls RJ, Kamm MA. Longutem results of overlapping anterior anal-spluncter repair for obstetric trama. Lancet $2000,355(9200): 260-5$.

11. Adang EM. Engel GL, Rutten FF, Geerdes BP, Baeten CG. Costeflectiveness of dymamic graciloplasty in patients with fecal incontinence. Dis Colon Rectum 1998;4167:725 33; discussion 733-4.

12. Baeten $C G$, Bailey HR, Bakka $A$, et al. Safety and efficacy of dynamic graciloplasty for fecal incontinence: report of a prospective, multicenter trial. Dynamic Graciloplasty Therapy Study Group. Dis Colon Recum 2000; 4 (6):743-5i.

13. Sielezneff I, Malout AI, Bartolo DC. Pryde A, Douglas S. Dynamic graciloplaspy in the treament of patients with faecal incontinence. Br / Surg 1999;8611):61-5.

14. Mavrantonis C. Billotti VL, Wexner SD. Stimulated graciloplasty for rreament of intractable fecal incontinence: critical influence of the method of stimulation. Dis Colon Rectum 1999,42(4):497-504. 
15. Matzel KE, Stadelmaier U, Hohenfelner M, Gall FP. Permanent electrostimulation of sacral spinal nerves with an implantable neurostimulator in treatment of fecal incontinence. Chrurg 1995;66(8):813\%7.

16. Vaizey C), Kamm MA, Roy AL, Nichols RI. Double-blind crossover study of sacral neve stimulation for fecal incontinence. Dis Colon Rectum 2000;43(3):298-302.

17. Wong WD, Congliosi SM, Spencer MP, at. The safety and efficacy of the artificial bowel sphincter for fecal incontinence: results from a multicenter cohort study. Dis Colon Rectum 2002:45191:11 39-53. 
MJGM Rongen MD EMM Adang $\mathrm{PhD}^{*}$
A Gerritsen van der Hoop MD PhD

CGMI Baeten MD PhD

\title{
One-step versus two-step procedure in dynamic graciloplasty
}

\author{
Department of surgery \\ University Hospital Maastricht \\ * Department of Health Organisation, Policy and Economics, \\ University of Maastricht \\ Maastricht, the Netherlands
}

Collorectal Dis. 2004, Mar;6(2): p. 113-6. 


\section{ABSTRACT}

Purpose: Bynamic graciloplasty, a proven treatment for end-stage fecal incontinence requires transposition of the gracilis-muscle around the anal canal and implantation of a pulse generator and intramuscular electrodes. In view of the risk of infection around the implanted material the implantation was initially not performed in combination with the perineal procedure but 6 weeks later. Sparing the patients an exila operation might be justified if morbidity is not increased. This study aimed to compare the combined single-stage with the two-stage procedures. Methods: Two groups of 13 patients were admitted to this prospective, matched control study according to waiting list ranking. They were matched for age, gender and etiology. Group I had transposition and transplantation combined; group II underwent these procedures separately with a 6-week interval. Continence, manometry, simulation parameters, quality of life results and adverse events were recorded.

Resuls: After a nean 52 days lollow-up infection rates were comparable in bollh groups, ts were continence rates, morbidity, anal manometry, stimulation paramelers and quality of life.

Conclusion, Outcome, norbidity and quality of life seem to be comparable. A ingle procedure avoids the feed for an extra admission and operation, so the ene-stage approa ch should be the standard procedure in dynamic graciloplasty. 


\section{INTRODUCTION}

Dynamic graciloplasty is a treatment for end-stage fecal incontinence based on construction of a neo-sphincter ${ }^{1,2}$. The gracilis muscle is wrapped around the anal canal and electrically stimulated to contract by an implanted pulse generator (IPG).

With an external device, a magnet or radio frequency transmitter, the patient can operate the IPG to control contraction and relaxation in order to be able to defecate or to hold stool. Earlier reports by several groups show good results with this technique ${ }^{3 ; 4}$.

The first dynamic graciloplasty ${ }^{5}$ was performed in a patient who alreacly had a conventional graciloplasty in the past. Ever since all dynamic graciloplasties in our clinic have been done in two steps. In the first operation a conventional graciloplasty was performed and 6 weeks later the electrodes and IPG were implanted. Following this procedure it was possible to assess the functional aspects of the transposed muscle before implanting the expensive stimulation material. Impaired function of the muscle however has been proven to be rare.

Initially several infections occurred, sometimes necessitating removal of the implanted material. The thought of performing an implant of electrodes and IPG together with a simultaneous perineal procedure was not considered appropriate, as this seemed to increase the risk of infection. Changing the antibiotic prophylaxis and applying local antibiotics during the operation decreased the rate of infection.

The experiences of other authors ${ }^{6,78}$, who performed transposition of the gracilis and implant of the IPG in one session, however, showed good results and low infection rates.

To compare one-stage dynamic graciloplasty with a two-stage procedure in a randomized trial approximately 500 patients are needed. This amounts the total number of patients treated worldwicle with dynamic graciloplasty over the last 10 years.

Since such a large trial is not feasible, a prospective matched control study was performed to gain an impression of outcome and safety of both approaches.

\section{Patients and Methods}

From September 1996 until June 199713 consequential patients, from the waiting list, underwent a one-step procedure (group I). In the same period, 13 


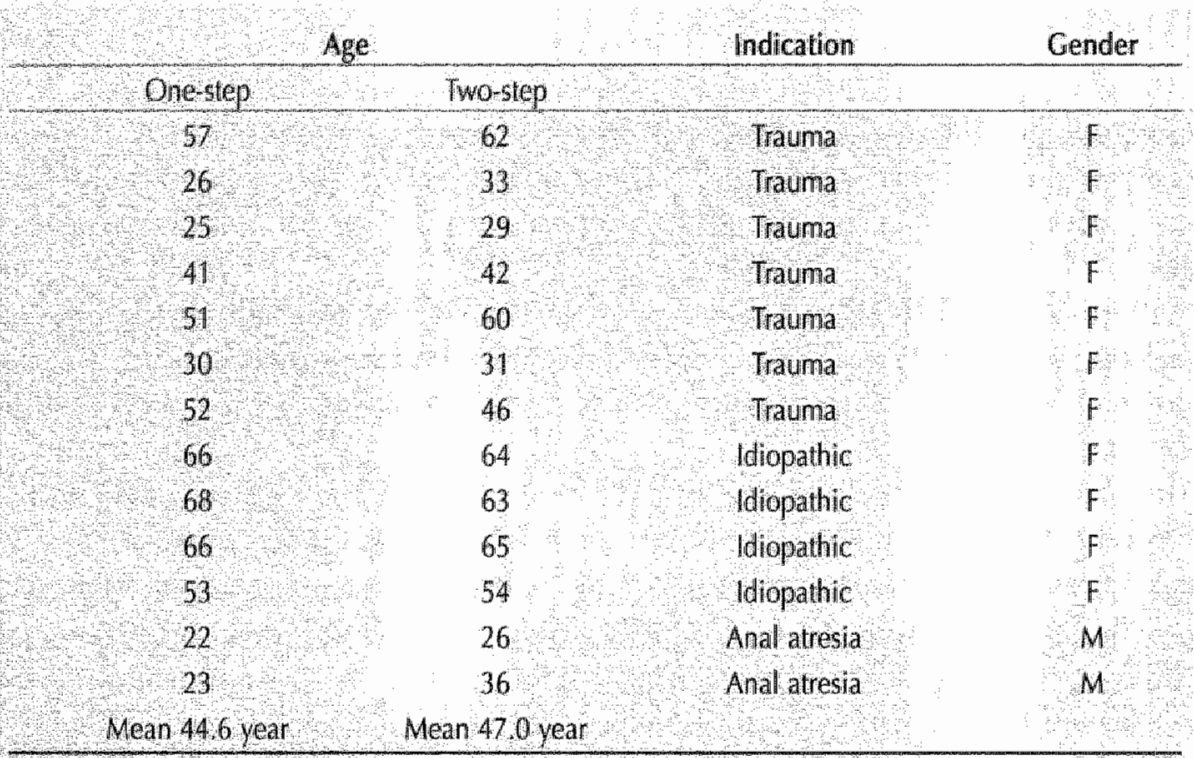

Table 1 Pairs natled for gender, age and etiology

patients(Table 1,) matched for gender, age and etiology, had a two-stage procedure a few months earlier (group II).

All 26 patients had end-stage incontinence for both liquid and solid stool. The mean duration of incontinence was 15.0 years in group I and 15.2 years in group II.

Prior continence surgery had been performed in the one-stage group eight versus eight times in the control group; anal repairs four versus five times, postanal repairs twice versus once, surgery for anorectal malformations twice in both groups. Biofeedback had been given to nine versus seven patients.

Preoperative work-up consisted of history, physical examination, anal manometry, electromyography (EMG) and quality of life investigation.

All patients were positioned in lithotomy position with the legs in moveable stirrups. With a long incision in the medial thigh and a short one just below the knee, the gracilis muscle was freed and the tendon cut as distally as possible through a separate incision below the knee. The neurovascular bundle was generally identified $8 \mathrm{~cm}$ distally from the origin of the muscle. Two incisions were made laterally of the anus just outside the external sphincter. After creation 
of an anterior tunnel and a posterior one just under the tip of the coccyx bone, another subcutaneous tunnel was created from the leg to the perineal incision. The muscle can be wrapped around the anus in several configurations, depending on muscle length and bulkiness. The gracilis tendon was sutured to the ramus inferior of the pubic bone ${ }^{2}$.

Two intramuscular electrodes (model 4300-35, Medtronic, Kerkrade, the Netherlands) were placed in the gracilis, one $4 \mathrm{~cm}$ distally from the neurovascular bundle, the other one near the intramuscular nerve branches. Optimal location of the latter was determined with electrical stimulation through an extension wire ${ }^{2}$. An incision in the lower abdomen was made to place the IPG (INTERSTIM, model 3023, Medtronic, Kerkrade, the Netherlands) below the rectus fascia. The electrodes were tunneled subcutaneously and connected to the IPG.

As prophylaxis, $24 \mathrm{~h}$ systemic antibiotics (Augmentin $B$; SB-Farma, Rijswijk, the Netherlands) as well as topic agents were given. Gentamycine solution was injected in the moveable sheet of the electrodes as the latter might provide a dead space prone for stasis and subsequent infection; Garacol (B) sponges (Shering-Plough, Amstelveen, the Netherlands) were used to cover the implants at closure of the fascia and subcutaneous tissue.

The patients in group I underwent the muscle wrap and the implant of the electrodes and IPG during the same operation. The patients in group II had the implant in a separate procedure 6 weeks after the gracilis transposition. A small incision in the upper thigh was made at the level of the neurovascular bundle of the gracilis. The proximal part of the muscle was freed for the implant. The pocket for the IPG was made in the same way as in the first group of patients.

For the transposition patients were admitted for 5 days. Implantation recuired another 3 days admission. For the one-step procedure, patients stayed in hospital for 5 days.

In both groups stimulation was started 6 weeks after the gracilis transposition

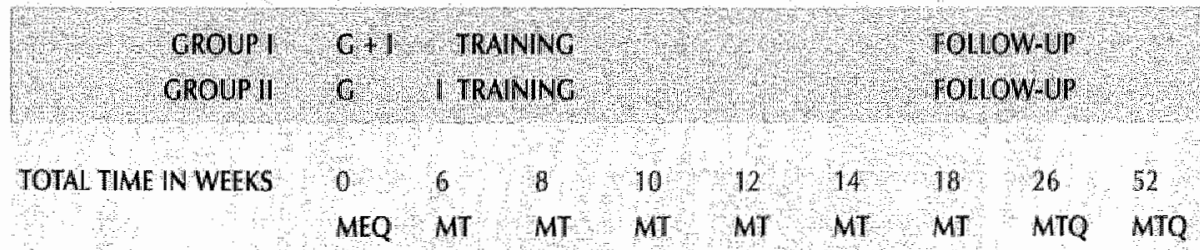

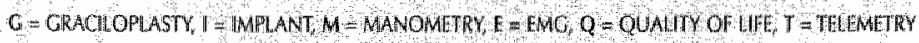

Figure 1: Timelable procedure 
(Figure 1). All patients underwent the same training protocol. This protocol consisted of an intermittent stimulation with an increase of actual stimulation time every 2 weeks during 2 months. The pulse-generator was adjusted telemetrically (Programmer console model 7432, Medtronic, Kerkrade, the Netherlands) under manometry control. After this training the stimulation amplitude was adjusted until continence was achieved. Scheduled outpatients visits took place at 3,6 and 12 months after starting the training, At all these visits, during which history was taken regarding continence as well as adverse events, anal manometry and telemetry were performed. With telemetry not only could stimulation parameters such as voltage, frequency and pulse width be adjusted, but also reprogramming of the electrode settings and measuring of impedance were allowed. Thus, a calculation of the current used for stimulation was possible in the two groups. Good contraction was defined as the contraction that was necessary to close the anal canal and give a pressure increase of at least $20 \mathrm{~mm} \mathrm{Hg}$. Anal manometry was performed in all patients as described before $^{2}$. Defecation frequency and postponement of defecation after first urge were noted preoperatively and at follow-up.

For continence classification the Williams scale $e^{9}$ was used.

Score 1 means continence to flatus, liquid and solid stool, score 2 means incontinence to flatus only, as score 3 will include incontinence for liquid stool. Score 4 refers to occasional and score 5 to frequent loss of solid stool. Scores 1 and 2 were considered to be successful.

\section{Quality of life}

This variable was included in the study to examine if quality of life differed between patients in group I and II. Quality of life was evaluated before the operation and at 6 and 12 months after, respectively, the one- and two-step procedures. Measurement was done by self-assessment as a so-called battery approach. Quality of life assessment consisted of a general health status measure, and two specific measures. Specifically the Short-Form-36 (SF-36) was used as a general health measure and includes multi-item scales to measure the following eight dimensions: physical functioning, role limitations due to physical health problems, bodily pain, social functioning, general mental health, role limitations due to emotional problems, vitality, energy or fatigue, general health perceptions. High scores on the SF-36 represent more favorable states 10;11. The Self Rating Depression Scale (SDS) by Zung was used and comprises 20 items to quantify the severity of current depression 12,13. Furthermore the State Trait Anxiety Index (STAI) also comprising 20 items to quantify the level of anxiety was included ${ }^{14,15}$. 
On both the SDS and the STAI higher scores represent unfavorable conditions. A visual analogue scale (VAS) was used ranging from "worst imaginable quality of life 0 "to "best imaginable quality of life 10 ". As fecal incontinence is a chronic illness response shift bias can be present in this study ${ }^{16,17}$. In order to measure response shift bias, Howard et al. ${ }^{18}$ recommended the extension of the conventional pre-testpost-test design with a retrospective pre-test thentest). This is accomplished by including a then-test (VAS) at the time of posttesting. At the post-test session, the subjects were asked to fill out the self-report measure iwice. First, they were asked to report how they perceive themselves to be at present (conventional past-test). Next, the subjects were asked to fill out the self-report measure in reference to how they now perceive themselves to have been prior to the intervention (retrospective pre-test).

Finally patients were asked whether their current health-state (post-operative) improved compared to their pre-operative health state.

\section{Statistical analysis}

Both groups were compared using the Mann-Whitney-U test for independent samples, within group analyses were done with the Wilcoxon signed ranks test. Analysis was done with the use of SPSS 8.0 for Windows( SPSS Inc, Chicago, II).

\begin{tabular}{|c|c|c|c|}
\hline & One-step & Two-Step & \\
\hline Defecation frequency pre-operative & 2,9 & 3 & times per day \\
\hline Defecation frequency last follow-up & $13^{4}$ & $1.7^{\circ}$ & limes per day \\
\hline Postponement defecation pre-operative & 16 & 63 & Seconds \\
\hline Postponement defecation last follow-up & $1652^{*}$ & $550^{*}$ & Seconds \\
\hline Amplitude last follow-up & 28 & 1,8 & Volt: \\
\hline \multicolumn{4}{|l|}{ Anal manometry } \\
\hline Basal pre-operative pressure & 53 & 50 & mmHg \\
\hline Basal post-openative pressure & 59 & 55 & $\mathrm{mmHg}$ \\
\hline Preoperative squeeze pressure & 76 & 82 & $m m H g$ \\
\hline Stimulated squeeze pressure llast follow-up & $100^{\#}$ & $118^{*}$ & $\mathrm{mmHg}$ \\
\hline Postoperative voluntary squieeze pressure & 159 & 146 & $\mathrm{~mm} / \mathrm{g}$ \\
\hline Operation time & 94 & $95^{1 .}$ & minutes \\
\hline Hospital admission & 5 & 8 & days \\
\hline
\end{tabular}

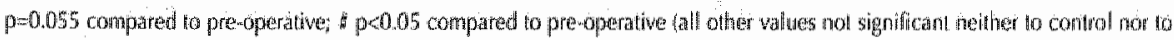

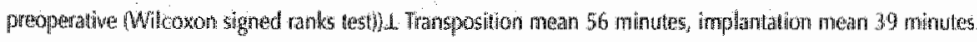

Table 2: Mean values one step procedure versus two step procedure 


\section{RESULTS}

\section{Continence}

After a mean follow up of 521 (one-step 510, two step 533) days in both groups continence was achieved in 85 and $69 \%$ in group I versus II, respectively. All patients, but one (belonging to group ly, had functional dynamic graciloplasty, proven not only by palpation but also with anal manometry and defecography. Changes concerning defecation frequency, postponement of defecation and anal pressures improved in both groups. (Table 2)

\section{Reason for failure}

The two failures in group $\mathrm{I}$, were both due to infections and subsequent implant removal. One of them, with also a very loose wrap, will require re-operation. Of the four failures in group II, one was attributed to chronic diarrhea. One patient had a serious disturbance in anorectal sensation, with lack of urge. In another patient with diarrhea, secondary to evacuation problems, a rectopexy for intussusception was performed in another hospital. This only worsened her evacuation. After diagnosing slow transit constipation, a colostomy was given to her. The last failure was an anal atresia patient with persistent diarrhea.

\begin{tabular}{llll} 
& & & Preoperative \\
\hline SF-36 & One-Step & Two-Step & All \\
Physical functioning & & & \\
Social functioning & $58+(23)$ & $70+(27)$ & $64+(24)$ \\
Role limitation due to physical problems & $64+(34)$ & $53+(29)$ & $58+(31)$ \\
Role limitation due to emotional problems & $79+(44)$ & $58+(44)$ & $44+(44)$ \\
Mental health & $76+(44)$ & $64+(41)$ & $70+(41)$ \\
Energy/fatigue & $68+(27)$ & $63+(23)$ & $65+(24)$ \\
Pain & $54+(28)$ & $58+(23)$ & $56+(25)$ \\
General health perception & $73+(34)$ & $80+(29)$ & $76+(31)$ \\
Change in health perception & $62+(28)$ & $61+(21)$ & $62+(24)$ \\
STAl & $48+(11)$ & $35+(22)$ & $42+(19)$ \\
\hline Zung & $48+(15)$ & $50+(17)$ & $49+(15)$ \\
\hline
\end{tabular}

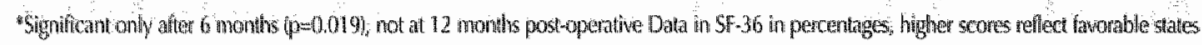

Table 3: Quality of life result 


\section{Morbidity}

In group 1 , necrosis of the distal part of the wrap occurred once, leading to an insufficient neo-sphincter. The patient was readmitted twice for 3 days and underwent perineal exploration. This patient was given a new muscle-wrap from the opposite leg, with new leads connected to the same pulse generator. This second procedure was done in a two-stage session. During the subsequent training an infection at the IPG site became manifest, necessitating explantation. This patient is now (pseudo) continent with the use of pump-driven enemas, and is relluctant to consider re-operations.

The other patient had, beside a too loose wrap, a persistent superficial infection located at the site of the IPG, also requiring implant removal. A tightening of the wrap and implantation of new leads and IPG will be planned.

Three patients had evacuation difficulties after the procedure. No abnormalities were found on rectal examination or delecography, nor were high basic anal pressures recorded in any of them. One of them recovered on bulk agents, another had great benefit from biofeedback therapy.

One patient had to undergo emergency resection of her sigmoid for diverticulitis. After restoration of colonic continuity she still was continent.

In group II urinary retention was noted post-operatively once. One patient suffered 6 months post-operative

12 months post-operative

\begin{tabular}{cccccccc} 
One-Step & Two-Step & All & One-Step & Two-Step & All & \\
$75+(19)$ & $66+(27)$ & $71+(23)$ & $69+(26)$ & $70+(24)$ & $70+(24)$ & NS \\
$66+(30)$ & $69+(28)$ & $67+(28)$ & $78+(30)$ & $71+(23)$ & $74+(24)$ & NS \\
$52+(36)$ & $44+(46)$ & $49+(40)$ & $73+(32)$ & $63+(45)$ & $67+(38)$ & NS \\
$61+(43)$ & $50+(50)$ & $57+(47)$ & $73+(43)$ & $67+(46)$ & $70+(44)$ & NS \\
$65+(22)$ & $68+(20)$ & $66+(21)$ & $75+(22)$ & $75+(19)$ & $75+(19)$ & 0.027 \\
$56+(22)$ & $56+(19)$ & $56+(20)$ & $63+(25)$ & $66+(20)$ & $65+(22)$ & NS \\
$48+(33)$ & $52+(29)$ & $50+(30)$ & $61+(31)$ & $62+(65)$ & $61+(28)$ & NS \\
$59+(27)$ & $52+(13)$ & $56+(21)$ & $69+(25)$ & $64+(18)$ & $66+(20)$ & NS \\
$69+(27)$ & $72+(18)$ & $70+(25)$ & $85+(30)$ & $71+(21)$ & $77+(24)$ & 0.001 \\
$42+(11)$ & $39+(8)$ & $40+(11)$ & $38+(16)$ & $32+(10)$ & $35+(12)$ & 0.001 \\
$37+(10)$ & $37+(9)$ & $37+(9)$ & $35+(13)$ & $32+(7)$ & $34+(10)$ & NS \\
\hline
\end{tabular}


from pain at the donor site due to stimulation, a colostomy for constipation (see above) resolved this problem in the end. Another had pain due to periostal reaction at the pubic bone during stimulation. Exploration was performed and after removal of the monofilament suture this problem was resolved.

In this group two patients also had evacuation problems, with no abnormalities on examination, defecography and manometry.

\section{Quality of life}

No significant difference was found in any of the eight dimensions of the SF-36 comparing the one-step with the two-step procedure. Also, no significant difference was found in the three other measures, SDS, STAI, and VAS when comparing both groups.

Meascirement
pre-operalive
6 months poscoperative

Data presented as means $0<0,05$

Table 4: Overall resulfs, conrecting for response shift bias.

Within group analyses showed that quality of life of patients in both groups increased after dynamic graciloplasty on some items of the SF-36, such as general mental health and change in general health perceptions. At 6 months after the operation patients experienced more pain, which decreased at 12 months to pre-operative levels. After dynamic graciloplasty patients became less anxious (STA). The Zung SDS showed no significant difference before and after the operation (Table 3).

The VAS showed no significant difference after the operation (Friedman Test, $\mathrm{p}=0.47$ ) (Table 4). Correcting for response shift bias (then-test) results in significant improvement after the operation within both groups (Friedman Test, $p=0.04$ ). Consequently the pre-operative established VAS differs significantly from the then-test. It was also assessed whether patient's VAS, respectively thentest ratings differed from the patient's perception if their health-state had improved after the operation. The pre-operative VAS differed significantly from the patients' perception about the improvement in their health-state $(p=0.034)$. The then-test did not differ significantly $(\mathrm{p}=0.577)$. Therefore patients who 
experienced improvement in their health state after the operation, also showed improvement on the VAS, when the then-test was compared to the postoperative VAS scores. The pre-operative VAS score compared to the postoperative VAS scores was not in accordance with the patients' perception of their health -state improvement.

\section{Telemetry}

In group la significant rise of current necessary for an adequate contraction was seen after 6 weeks of unused electrodes. In group li the current at the time of implant was the same as in group I six weeks earlier. In both groups a gradual rise of current was observed during the training period; it stabilized after 12 weeks (Figure 2)

\section{Current in time}

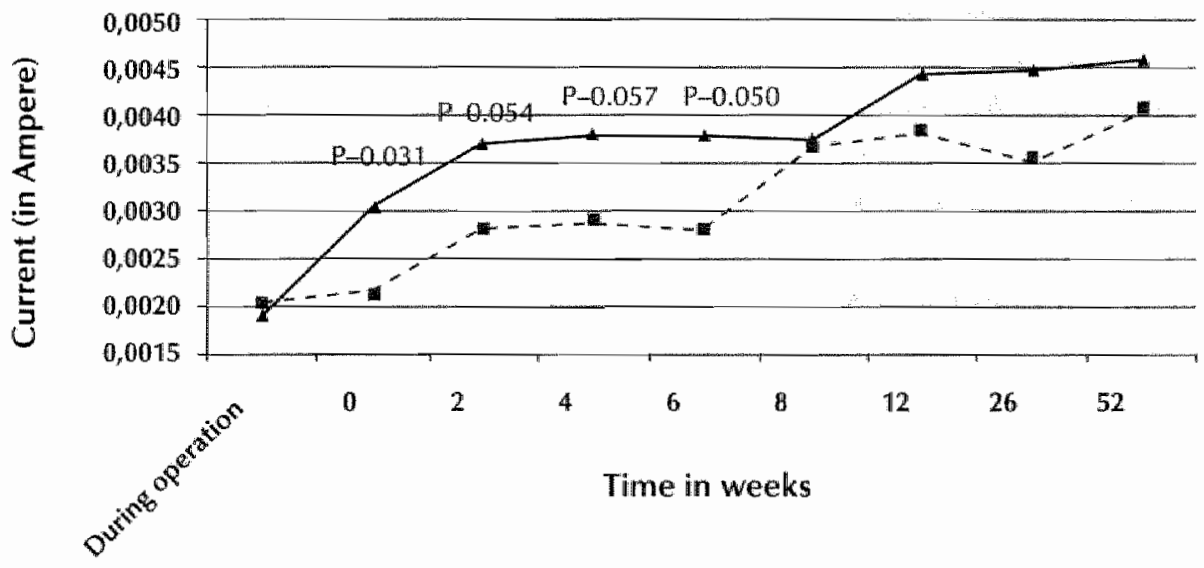

Only $p$ walues of the beginning of the training ane shown. Mannw Whithey Test for nom-parametric data was used.

$\Lambda$ - group : $\mathbf{\square}=$ group

Figure 2: Development of current in time

\section{DISCUSSION}

A functioning dynamic graciloplasty does not always lead to restoration of continence. Factors involved in continence beside good sphincter function 
include stool consistency, pelvic floor function, anorectal propioception and rectal compliance. This may explain the fact that the etiology group with the poorest results is the anal atresia group ${ }^{2,19}$, in which most co- factors are also disturbed.

In all patients treated with dynamic graciloplasty it was noted that in time higher voltages are required to generate appropriate contraction of the gracilis muscle. One reason for this could be that around the electrode, as around any foreign body, fibrosis will form. Fibrosis will impair electrical conduction, resulting in an increase of necessary current. Another reason is that electrical stimulation changes muscle properties from a fatigable one into a less fatigable one, allso leading to loss of strength. To generate an equal anal pressure a higher voltage is needed. This study made it possible to compare both factors. During the 6 weeks that the electrodes were present in group I no electrical stimulation was given. This means that the significant rise in current necessary for contraction at the start of stimulation can be explained by the formation of fibrosis. Later on it probably is the combination of fibrosis and muscle change. In group II the start of the stimulation is one day after the implant and therefore the current rise was a combination of muscle change and fibrosis formation that started at that time. Interestingly, as seen in figure 2 , the current rise stopped after several months. The change in muscle was then completed and one could expect that no further fibrosis would be formed. Overall quality of life increased after the operation, especially when corrected for response shift bias.

As already mentioned before, this trial lacks true statistical power to draw wellfounded conclusions. Over 500 patients would be needed to make solid statistical judgements. Since this exceeds the number of dynamic graciloplasties performed worldwide over the last 10 years, one can see the difficulties in performing such a study.

Functional oulcome and quality of life do not appear to be influenced by the procedure. On theoretical grounds one would expect a higher morbidity rate with an emphasis on infections, as foreign bodies are implanted in combination with a perineal operation. Following the intention to treat principle two onestep patients had implant infections. Only one of these arose after the original procedure. Cynically enough the other infection occurred after a two-step approach at a re-intervention.

Within our last 100 patients (53\% one-stage procedures) five infections occurred, requiring implant removal. Two of them were one-stage procedures, the above-mentioned and one in a morbid obese female. The other three were two-stage procedures, one in a male with recurrent perineal infections, the 
other two after re-interventions that necessitated re-opening of the IPG-pocket. Given the fact that an extra operation has its own morbidity, this might outbalance the negative aspects for the choice for a one-stage procedure. Furthermore, an earlier study 20 showed that the one step procedure was less expensive than the two-step procedure. This study shows that clinical effectiveness and quality of life do not seem to be influenced by the choice of procedure so the conclusion must be that the one-step procedure is more cost-effective than the two-step procedure. Therefore we recommend that the one-step procedure is the procedure of choice when performing dynamic graciloplasty.

After concluding this trial, all dynamic graciloplasties in our clinic were done as an one-stage procedure, so far showing no increase in infection rate. However, if a complication occurs during the operation, e.g. rectal perforation, implantation is postponed for 6 weeks. 
One-step versus two-step procedure in dynamic graciloplasty 


\section{REFERENCES}

1. Baeten $C G$, Konsten J, Spaans F, al: Dynamic graciloplasty for treatment of hecal incontinence. Lancet 1991;338:1163-1165.

2. Baeten $\mathrm{CG}_{3}$ Geerdes $\mathrm{BP}$. Adang $\mathrm{EM}$, al: Anal dynamic graciloplasty in the treatment of intractable fecal incontinence. NEngl/.Med. 1995;332:1600-1605.

3. Cavina E: Outcome of restorative perineal graciloplasty with simultaneous excision of the anus and rectum for cancer. A ten-year experience with 81 patients. Dis. Colon Rectum 1996;39:182-190.

4. Williams NS, Hallan RI, Koeze TH, Watkins ES: Construction of a neorectum and neanal sphincter following previous proctocolectomy. Br. Surg. 1989;76:1191-1194.

5. Baten C, Spaans F, Fluks A: An implanted neuromuscular stimulator for fecal continence following previously implanted gracilis muscle. Report of a case. Dis. Colon Rectum 1988;31:134-137.

6. Rosen HR, Feil W, Novi G, Zoch G, Dahlberg S, Schiessel R: The electrically stimulated (dynamic) graciloplasty for faecal incontinence-first experiences with a modified muscle sling. int/.Colorectal.Dis. 1994;9:184-186.

7. Seccia Menconi C. Balestri R, Cavina E: Study protocols and functional results in 85 electrostimulated graciloplasties. Dis. Colon Rectum 1994;37:397-904.

8. Williams NS, Hallan RI, Koeze TH, Watkins ES: Restoration of gastrointestinat continuty and continence after adominoperineal excision of the rectum using an electrically stimulated neoanal sphincter. Dis.Colon Rectum 1990;33:561-565.

9. W/illiams NS, Patel J, George BD, Hallan RI, Watkins ES: Development of an electrically stimulated newanal sphincter. Lancet 1991;338:1166-1169.

10. Ware), Sherbourne CD: The MOS 36-item short-form health survey (SF-36). I. Concepual framework and item selection. Med.Care 1992;30:473-483.

11. Ware J, Kosinski MKS: SF-36 physical and mental health summary scores; a user's manual, Boston, MA, 1994:

12. Zung W. A self-rating depression scalle. Arch.Can Psychiatry 1965:13:63-70.

13. Dijkstra P: The self-rating depression scale of Zung (in Dutch), in Praag H, Rooymans $M$ (eds): Amsterdam, Even Bohn: 1974:56-67.

14. Spieberger $\mathrm{C}$, Gorsuch R, Lushene Re: STAI manual for the state frait anxiety ivventory, Palo Alto, Califormia, Consulting Psychologists Press Inc; 1970 :

15. Ploeg Hwd, Defares $P$, Spielberger $C$. En nederlandstalige bewerking van de Spielberger State-Trait Anxiety Inventory; de Zelf́beoordelings Vragenlijst. De Psycholoog 1980:15:460-467.

16. Adang, E.M.M., Kootstra, G., Engel, G.L., Hooff, I.P. van, \& Merkelhach, H.L.G.J. Do retrospective and prospective quallity of life assessments differ for pancreas-kidney transplant recipients? Transplant Intemational 1998; 11: 11-15 
17. Adang, E.M.M., Kootstra, C., Baeten, C.G.M.l. \& Engel, G.L. Quality-of-life ratings in patients with chronic illnessess. Journal of the American Medical Association 1997 ; $277: 1038$

18. Howard, G.S., Ralph, K.M., Gulanick, N.A., Maxwell, S.E., Nance, D.W., \& Gerber, S.K. Internal invalidity in pretest-posttest self-repont evaluations and a re-evaluation of retrospective pretests. Applied Psychological Measurement 1979; 3:1-23

19. Baten $C G$, Konsten 1, Heineman $E$, Soeters PB: Dynamic graciloplasty for anal atresia. 1. Pediatrsung. 1994;29:922-924.

20. Adang $\mathbb{E}$, Engel $\mathrm{GL}$, Ruften $\mathrm{FH}_{3}$ Geendes $3 \mathrm{P}$, Baeten $\mathrm{Cl}$. Cost-efrectiveness of dynamic graciloplasty in patients with fecal incontinence. Dis. Colon Rectum 1998;41:725-733. 


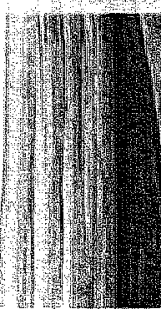


J Konsten MD, PhD*

$M]$ Rongen $M D^{*}$

OA Ogunbiyi MD, FRCS \#
A Darakhshan MD CGMI Baeten MD, PhD*

NS Williams MS, FRCS\#

\section{Comparison of Epineural and Intramuscular Nerve Electrodes for the Stimulated Graciloplasty}

\# Academic Department of Surgery, The Royal London Hospital, Whitechapel, London

* Department of Surgery, University Hospital Maastricht, the Netherlands.

Dis Colon Rectum, 2001. 44(4): p. 581-6 


\section{ABSTRACT}

Objective. Two different techniques have been developed to stimulate the gracilis muscle when it is used in anal neosphincter reconstruction. These are direct neural stimulation and intramuscular electrode stimulation. The aim of this study was to compare these techniques

Methods: Comparison was made of gracilis anal neosphincter reconstruction using neural stimulation (Royal London IJospilal in the United Kingdom) with the intramuscular muscular method Universitw Hospital Maastricht in the Nether ands). The United Kingdom data were obtained from a retrospective database, whereas the Netherlands data were gatlhered prospectively.

Results. A sulecessful outcome was achieved in 46 out of 81 patients $(57 \%$ ) in London and 148 out of 200 cases $(7.4 \%)$ in the Maastricht study Chi-sciuared $=7.2$ P<0.01). There was no significant difference between the two techniques in voltage required for stimulation of the neosplineter muscle during a ten-year period. Re-operalive surgery for electrode failure or dislocation was recuired in $21(26 \%)$ palients in the Lonelon study whereas only four $(2.7 \%)$ of the Maastricht cases reguired such procedures (Chi-squared $=37.8, P<0.05$ ). The high electrode plate failure rate th the London series was related to the source of manufacture.

Conclusions. Boll neural and intramusculviv lerve techmiques provide effective long-tern stimulat on of the gracilisanal neosphincter: 


\section{INTRODUCTION}

An electrically stimulated gracilis neosphincter or dynamic graciloplasty is a novel approach for otherwise unmanageable fecal incontinence ${ }^{1,2}$. A new sphincter is created by circumanal transposition of the gracilis muscle and subsequent stimulation with an implanted electrical device. The aim of electrical stimulation is a sustained contraction of the transposed gracilis muscle. Such a contraction closes the anal canal and replaces a deficient sphincter. The stimulation can be turned off with an external device to allow defecation. Electrical stimulation induces a change of muscle fiber phenotype from type II fast twitch into type I fatigue resistant fibers. Fiber type conversion is considered essential for dynamic graciloplasty ${ }^{3}$. However, if electrical stimulation ceases for a prolonged period of time the fibers revert to their original state of type II, easily fatigued muscle fibers, which are less suitable to function as a neosphincter".

Two different techniques have been developed to stimulate the transposed gracilis muscle. In London, Williams ${ }^{5}$ used an electrode plate on the nerve to the gracilis muscle. In Maastricht, Konsten en colleagues ${ }^{6}$ developed an alternative method in which two electrodes are sewn into the transposed gracilis. In this way the intramuscular nerve branches are stimulated Epineural or direct nerve stimulation was criticized recently, claiming inferior results due to electrode displacement or fibrosis or both. ${ }^{7,}$. In addition, several groups have directed their attention to impaired rectal emptying after dynamic graciloplasty ${ }^{9-11}$. The aim of this study was to analyze the success and failure of an electrostimulated gracilis neosphincter from two large centers using different techniques of neosphincter stimulation.

\section{Patients AND Methods}

\section{Patients}

Between 1986 and 1999, 305 patients underwent gracilis neosphincter surgery for endstage faecal incontinence at the two centres, 104 in London and 201 in Maastricht. Data from London was obtained by retrospective case note review. Fourteen patients who were lost to follow-up and nine patients who underwent adynamic graciloplasty were excluded from the study. The Maastricht data were obtained from a prospective database in London. One patient was excluded as he had a pulmonary artery rupture after surgery and died at home, 2 weeks later. Patients awaiting stoma closure after reconstructive surgery in both centres 
were also excluded from the study. Pre and post-operative anorectal physiology was performed according to previously described protocols 1,2. The demographic data on the patients studied are given in Table 1 and the causes of incontinence were classified as previously described by Madoff et al (Table $2)^{12}$. Forty-eight ( $59 \%$ ) patients in the London study and $118(59 \%)$ patients in the Maastricht study had previous surgery for fecal incontinence.

\begin{tabular}{lcc} 
& & \\
Number of patients & London & \multicolumn{1}{c}{ Mastricht } \\
\hline Median age in years and range & 81 & 200 \\
Sex (male/female) & $43[13-75]$ & $50[13-77]$ \\
Median duration of incontinence in years and range & $30 / 51$ & $49 / 51$ \\
Maximal anal resting pressure (median mm Hg) & $6[1-33]$ & $9[1-47]$ \\
Increase during anal squeeze as percentage & $26[7-104]$ & $51[10-128]$ \\
Threshold rectal sensallon (ml) & $192 \%$ & $145 \%$ \\
Maximum tolerable rectal volume $(\mathrm{ml})$ & $25[8-231]$ & $40[8-180]$ \\
\hline
\end{tabular}

Table 1 Patrenthanacteristics

\begin{tabular}{lcc}
\hline CFI & London & Maastricht \\
\hline AFI & $19(24 \%)$ & $28(14 \%)$ \\
\hline IAR & $47(58 \%)$ & $153(76,5 \%)$ \\
\hline
\end{tabular}

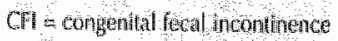

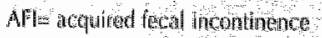

TAR=lotal arionect reconstriction

Table 2: Guses of incomtinence

\section{Operative Technique}

\section{Epineural stimulation (London technique)}

The electrically stimulated gracilis anal neosphincter procedure using neural stimulation was performed as previously described1. However, in the latter three 


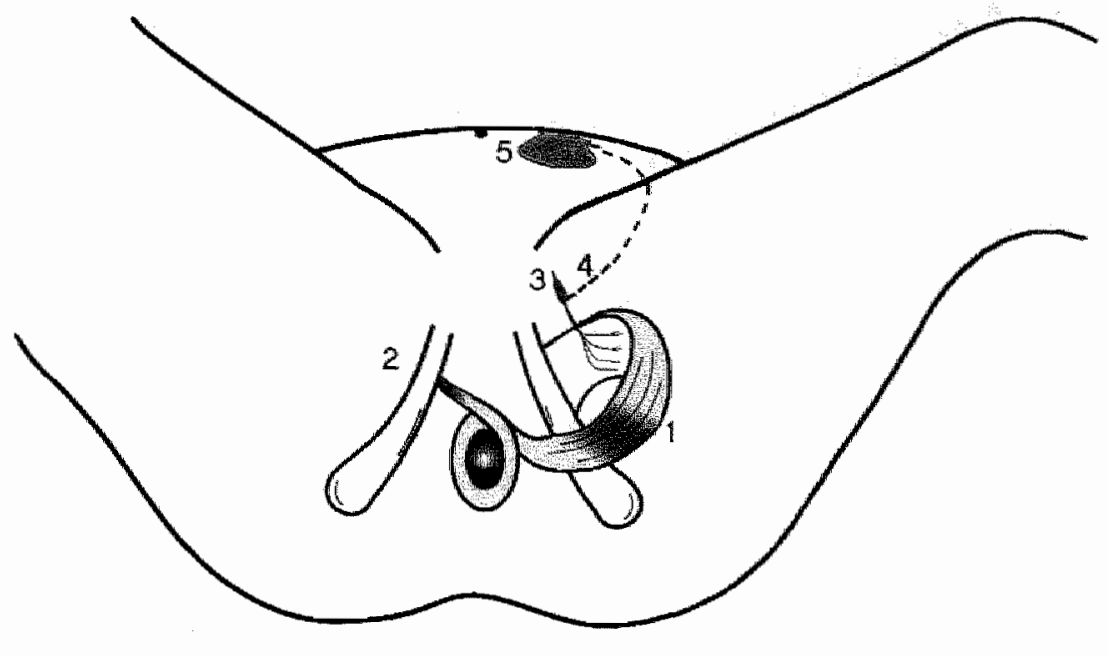

$f$ =graciloplasty, $2=0$ pposite ramus inferior of os pubis, $3=$ rene to graciloplasty

4 sonerwe electrode (dotted line) $5=$ implanted stimulator

Figure 1: epineural nerve stimulation

years of the study period, the procedure underwent a few modifications. Division of the blood supply to the distal half of the muscle, performed as a separate procedure before mobilization of the muscle, has been abandoned, because it did not seem to confer any significant benefits in regards to the outcome of the procedure. Early in the London experience, the electrode was sutured to the point with the lowest contraction threshold at the peripheral nerve branches. It is now sutured over the main nerve trunk in its long axis to the underlying adductor brevis with non-absorbable silk (Figure 1), because this was associated with better muscle contraction. Various electrodes were used in this study. Sixty-two patients had a Niceß) electrode (NICE Technologies Inc., Fort Lauderdale, FL, USA), 3 patients had a primary resume(B) quadripolar electrode (model 3586, Medtronic(B) Minneapolis, MN, USA), and 16 patients had a bipolar Medtronic $(B$ electrode (model 3961, Medtronic $B$ Minneapolis, MN, USA). The latter electrode is being used to the present day. It has a paddle with two circular-shaped platinum iridium electrodes facing the nerve. The paddle is sutured to the underlying adductor muscle. A covering loop stoma was constructed in 72 patients $(80 \%)$. Stimulation was delayed for at least 10 days after transposition and performed as previously described ${ }^{1}$. 


\section{Intramuscular nerve stimulation (Maastricht technique)}

The patient is in the modified Lloyd-Davis position and an approximately $15-\mathrm{cm}$ incision in the upper leg is made. The proximal part of the upper thigh incision is at least $5 \mathrm{~cm}$ proximal from the groin. A $2-\mathrm{cm}$ incision is made below the knee to dissect free the distal gracilis tendon which is divided at its insertion. Distal vascular pedicles are divided and the muscle is mobilized. The main nerve trunk is identified with a disposable stimulator. The main vascullar and nerve trunk are left within their connective tissue and not dissected free. Six weeks after the transposition or later during this study at the time of gracilis mobilization, the optimal electrode position is determined using an external stimulator. If gracilis mobilization and electrode implant was done in one procedure, the electrodes were positioned before circumanal transposition of the gracilis muscle which is more easily performed. The position of the anode (positive electrode) is $3 \mathrm{~cm}$ distal to the entry of the main nerve, although this is not critical. The optimal site of the cathode (negative electrode) is located with a testing needle so that a brisk contraction of the gracilis muscle is obtained with low stimulus strength (threshold). This position is always near the entry point of the nerve into the muscle. The contraction is caused by stimulation of intramuscular nerve branches. Both cathode and anode are a flexible coil

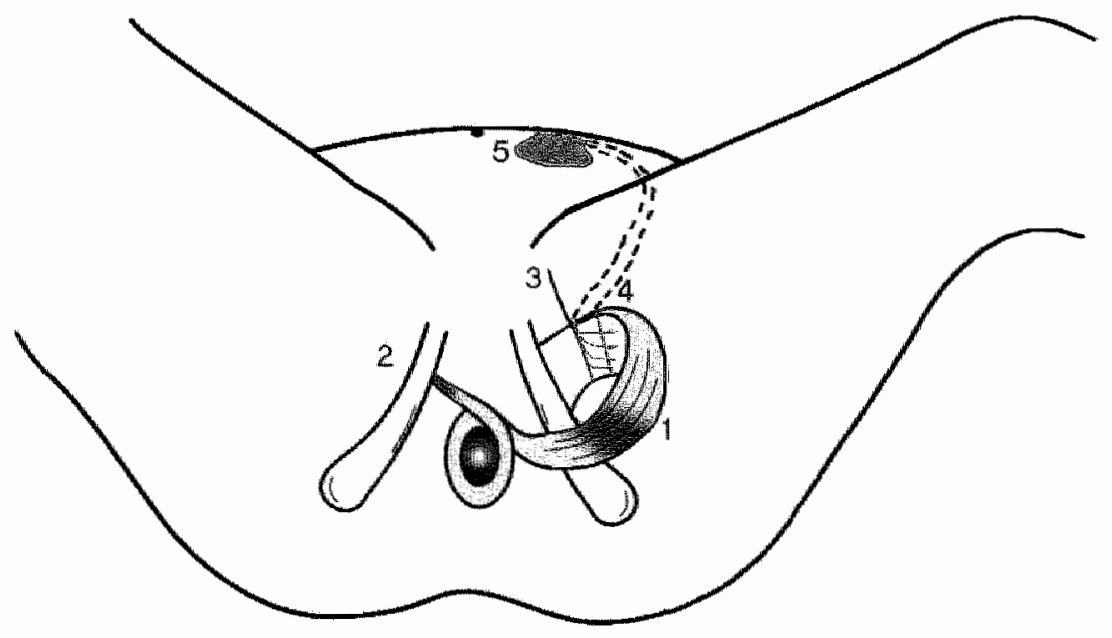

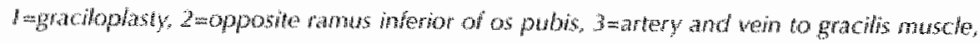

Anintramuscular dectrode (doted the) simplanted stumulator

Figure 2: intramuscular nerwe stimulation 
wire of platinum iridium. These electrodes are woven into the transposed gracilis muscle from the medial to the lateral side and fixed at both muscle sides with non-absorbable sutures (Figure 2). The first patient had a screw electrode as cathode, which was replaced in 1994 with intramuscular electrodes ${ }^{13}$. All other patients had the same intramuscular electrodes (Medtronic(B), Kerkrade, the Netherlands). Tunnels are created bluntly around the anal canal. The gracilis is transposed circumanally in the best suitable configuration. Two fingers were allowed between the graciloplasty and the anal canal before fixation of the tendon to the ramus inferior of the os pubis. Stimulation was delayed after transposition for at least six weeks in all patients ${ }^{2}$. A covering loop stoma was not performed, although $39(19,5 \%)$ patients had a stoma at the time of referral to the Maastricht Liniversity Hospital. These stomata were closed once neosphincter muscle training was complete.
1 continent to salids licuirids and flatus
$1 /$ continent to solids and tiquids but not flatus
III continent to salids but occasional episades af liquid incontinence
IV occasional episodes of solids and frequent ep isodes of incontinence of liquids
$\checkmark$ frequent episodes of incontinence of solids and liquids or stoma

\section{Table 3 Continence scores}

Antibiotics were administrated perioperatively in both groups. Clinical outcome was assessed using a five-point scale (Table 3). Success was defined as scores 1 and 2. Scores 3-5 and the construction of a permanent stoma were considered as failures. All procedures were performed by or in the attendance of the senior authors (N.W. or C.B.).

\section{Analysis}

Statistical analysis was performed using chi-squared analysis for comparison between groups and analys is of variance for repeated measurements. " The strength of the stimulus (voltage) required for a good contraction of the transposed muscle was compared from the time of insertion of the stimulator until ten years later. Electrode replacement because of inaclequate function was analyzed separately. Failures of the technique were classified into three categories as reported by Geerdes et al. ${ }^{15}$; 1) technical (inadequate contraction of the gracilis muscle, perforation of the anal canal and electrode or stimulator related problems); 2) infectious; and 3) physiological complications (overflow 
incontinence, soiling, non-distending rectum $m_{r}$ and failure of rectal evacuation). The number of patients complaining of impaired evacuation and those patients with additional procedures such as Malone appendicostomy or colonic conduit procedures for constipation were also analyzed ${ }^{16}$.

\section{RESULTS}

The proportion of patients suffering from congenital incontinence and who had a total anorectal reconstruction was significantly larger in the London series $(42$ versus $24 \%$, chi-squared $=8.7, \mathrm{P}<0.01$, Table 2). A successful clinicall outcome was achieved in 57 and $74 \%$ of cases in the London and Maastricht studies. respectively. Subgroup analysis revealed that the proportion of patients with a successful outcome in the acquired fecal incontinence group was significantly greater in the Maastricht study (Table 4). Technical failure occurred in 15\% of the London study as compared with $7 \%$ in the Maastricht study. infection as a cause of failure was significantlly more common in the London (15\%) as compared with the Maastricht study (4\%) (Chi-square 8.6, P<0.05) (Table 5). The infections in the London patients were all associated with the Nice@ electrode.

The stimulation voltage required to achieve a good contraction of the neosphincter

\begin{tabular}{|c|c|c|c|}
\hline & London (\%) & Maastricht $(\%)$ & $\mathrm{p}$ \\
\hline Congenital faecal incontinence & $9 / 19(47)$ & $13 / 28(46)$ & 0.4 \\
\hline Acquired faecal incontinence & $30 / 47(64)$ & $123453(80)$ & $<0.05$ \\
\hline Total anorectal reconstruction & $7 / 1547)$ & $12 / 19(63)$ & 0.3 \\
\hline Total & 4681157 & $148 / 200(74)$ & $0_{0.05}$ \\
\hline
\end{tabular}

Table 4: success

\begin{tabular}{|c|c|c|c|}
\hline & London (\%) & Maastricht $(\%)$ & $P$ \\
\hline Technical & $12(15 \%$ & $(14(7 \%)$ & 0,07 \\
\hline Infection & $12(15 \%)$ & $8(4 \%)$ & $0<0.05$ \\
\hline Physiology & $1114 \%$ & $30(15 \%$ & 09 \\
\hline Total & $35(43 \%)$ & $52(26 \%$ & p<0,0s \\
\hline
\end{tabular}

Table 5: Causes of falture 
was lower $(0.6)$ for epineural stimulation than for intramuscular nerve stimulation (1.0 volt) at the beginning of this study. However during follow-up the voltages were about the same. No statistical differences were found (Table 6).

\begin{tabular}{lll}
\hline 0 & London & Maastricht \\
1 & $0.6[0.1-4.0] n=74$ & $1.0[0.3-4.4] n=200$ \\
2 & $2.0[0.2-10.5] n=43$ & $2.1[0.5-6.8] n=149$ \\
3 & $3.0[0.9-8.4] n=21$ & $2.5[0.7-7.7] n=110$ \\
4 & $2.9[0.9-6.6] n=14$ & $2.4[0.7-7.0] n=70$ \\
5 & $2.9[0.9-10.5] n=12$ & $3.5[0.6-7.0] n=42$ \\
6 & $3.0[1.5-4.5] n=7$ & $2.6[0.8-5.31 n=38$ \\
7 & $3.0[1.5-6.0] n=5$ & $3.1[1.0-6.5] n=17$ \\
8 & $2.4[1.5-4.5] n=4$ & $3.1[1.0-6.5] n=17$ \\
9 & $3.0[3.0-4.8] n=3$ & $3.0[1.0-4.1] n=18$ \\
10 & $3.0[3.0-3.75] n=3$ & $2.7\lfloor 1.8-5.01 n=6$ \\
\hline
\end{tabular}

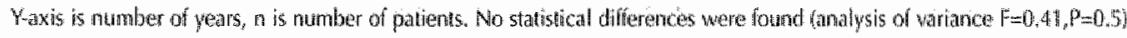

Table 6: Stimulation woltage and range

\begin{tabular}{|c|c|c|c|}
\hline Primary electrode & Number of patients & Success $(\%)$ & Lead replaced $(\%)$ \\
\hline \multicolumn{4}{|l|}{ London patients } \\
\hline Nice & 62 & $31(50)$ & $17(27)$ \\
\hline Medtronic quadripolar & 3 & $2(67)$ & $2(67)$ \\
\hline Medtronic bipolar & 16 & $13(81)$ & $2(13)$ \\
\hline
\end{tabular}

Table 7: Comparison of Neunal Electrodes Used by The London Croup

Surgery for electrode failure was performed in $21(26 \%)$ patients with epineural stimulation (Table 7 . However, 19 ellectrodes were replaced in the London series before the currently used bipolar electrode was introduced. Two of these bipolar electrodes were replaced, one was displaced and the other had a wire fracture. In Maastricht $4(2 \%)$ intramuscular nerve electrodes were replaced because of insufficient neosphincter function $(P<0.01)$.

The threshold for rectal sensation did not predict a good outcome $(40-\mathrm{ml}$ for 
patients with success as well as failures in the Maastricht study and $25 \mathrm{ml}$ for both groups in the London study). Impaired evacuation was noted in $32(40 \%)$ patients in the London study. In 21 patients $(26 \%)$ a colonic conduit was performed to aid rectal evacuation. Twenty-seven patients $(13,5 \%)$ in the Maastricht group had problems emptying their rectum after a dynamic graciloplasty. Two patients had a Malone appendicostomy.

\section{Discussion}

This is a partly retrospective analysis of electrically stimulated gracilis neosphincter reconstruction, which limits its conclusions. However, it is the largest study (281 patients) reported so far, and the lessons learned will be valuable in the future development and application of this technique. The success rate was better in the patients who had intramuscular nerve stimulation (Maastricht method; $74 \%$ ) as compared with those patients underwent epineural stimulation (London method; $57 \%$ ). However in the Maastricht group more patients had acquired incontinence (Table 2), which is associated with a better outcome $^{12}$. The intramuscular nerve electrode was stable. Only 4 of 200 patients required electrode replacement. On the other hand 21 out of $81(26 \%)$ patients from the epineural stimulation group needed electrode replacement. Nineteen patients had this replacement before the current bipolar electrode was used (Table 7). The new bipolar electrode, which was implanted in 16 patients, was replaced in one patient as a result of dislocation. This was an improvement over the Nice equipment used earlier in the London study. The Maastricht group has gained experience during the last decade with the intramuscular nerve technique, whereas the London group has only recently switched to the currently used bipolar nerve electrode manufactured by Medronic 8 . The conclusions from Rius et al ${ }^{7}$ and Mavrantonis and Wexner ${ }^{8}$ that the success of a graciloplasty is dependent on the method of stimulation can not be drawn from a small series with limited follow-up. However, in this much larger series derived from two centers, identical results for the Nice $\mathbb{B}$ equipment were found. Although the early results with the Medtronic(B) bipolar nerve electrodes are encouraging, no definitive statements can as yet be made regarding long-term outcome because of the small numbers and short follow-up ${ }^{16}$. Proper evaluation of the two methods would require a prospective, randomized, controlled trial using identical stimulators and electrodes manufactured by the same company. In London, an independent body is currently performing a prospective review of the outcome of 
neosphincter reconstruction using neural stimulation during a five-year period $(1997-2002)$.

The voltage required to stimulate the neosphincter was lower in the epineural group as compared with the intramuscular nerve group in the early phase of stimulation. However, this difference disappeared at one year. Fibrosis around the electrodes probably contributes to this, because an increased threshold of stimulation was noted in both groups on long-term follow-up. Conversion from type II to type I muscle fibers also leacls to an increase in the required voltage of stimulation ${ }^{6}$. The epineural stimulation technique has the advantage of a maximal recruitment of all motor units into the neosphincter muscle, whereas the intramuscular nerve stimulation technique stimulates only those peripheral branches in the neighborhood of the electrode. So far this maximal recruitment of a dynamic graciloplasty has not resulted in a better outcome. This may have been because of poor quality of the neural electrodes used by the London group in the first part of the study period. Fixation may be considered to be the main problem tor the epineural stimulation technique, because the nerve to the gracilis is quite small. Even if the electrode paddle is fixed to the relative immobile adductor magnus muscle, dislocation may occur although this happened in only one of the 16 patients with the new Medtronic $(B)$ electrode. Intramuscular nerve stimulation uses the complete diameter of the graciloplasty, so that dislocation seems less of a problem.

Other factors may explain the observed percentage of success between the epineural and intramuscular stimulation technique. Epineural stimulation requires full mobilization of the vascular pedicle to reach the nerve and fix the electrode paddle. Although the transposed gracilis, which is tethered by its proximally based vessels, can entirely encircle the anal canal pedicle without undue tension, the mobilized vessels may kink with subsequent ischemic damage to the graciloplasty. Furthermore, it is possible that early stimulation of the neosphincter as used by the London group, may negatively affect outcome. This has been demonstrated to be the case in animal experiments ${ }^{17}$. In addition, a stoma was used routinely by the London group. In a recent multicenter series of dynamic graciloplasty using intramuscular nerve electrodes, a protective stoma influenced the outcome negatively ${ }^{12}$. It may be that after stoma closure the patients do not know how to operate their neosphincter, because the rectum has not been subjected to intraluminal filling for a few months. However, because no randomized studies on the use of defunctioning stomas have been reported, it is impossible to make any judgments on their effect on eventual outcome. 
Constipation is a serious problem after dynamic graciloplasty using both techniques of stimulation. Additional procedures such as construction of an antegrade colonic conduit or Malone procedure may be necessary to achieve satisfactory evacuation ${ }^{18}$. Some patients have a combination of constipation and incontinence before surgery. An electrically stimulated gracilis neosphincter can cause an outlet obstruction, especially if the sling is placed around the anal verge instead of the anal canal. Furthermore, in patients with an anorectal atresia and those who had extensive anal surgery, there may be scarring around the canal which makes it impossible to do a high anal canal wrap. In addition, some patients can stretch their gracilis muscle during defecation so that paradoxically it closes the anal canal. Defecography and anorectal physiology were unable to predict which patients would suffer from constipation after an electrostimulated gracilis neosphincter ${ }^{19}$. The difference in anal pressure (Table 1) between the two groups can be explained by the various catheters which have been used ${ }^{1,2}$. Preoperative rectal sensation in the Maastricht and London series was similar for patients who experienced success or failure. One might speculate that infection can cause fibrosis and consequently obstruction of the anal canal. The problem of constipation needs prospective evaluation using more sophisticated techniques such as ambulatory manometry and scintigraphy.

\section{CONCLUSION}

We demonstrated that a dynamic, or electrostimulated, gracilis neosphincter avoids a stoma in $69 \%$ of patients. Epineural and intramuscular nerve stimulation are able to activate a graciloplasty for more than ten years, which is encouraging for patients with incapacitating fecal incontinence. In the future a randomized trial can select the optimal method of stimulation. 


\section{ReferenCES}

1. WHlliams NS, Patel I, George BD, Hallan RI, Watkins ES. Development of an electrically stimulated neoanal sphincter. Lancet 1991;338:1166-9.

2. Baeten $C G$, Konsten J, Spaans F, ef al. Dynamic graciloplasty for treatment of faecal incontinence. Lancet 1991;338:1163-5.

3. Konsten 1, Baeten CG, Havenith MG, Soeters PB. Morphology of dynamic graciloplatsty compared with the anal sphincter. Dis Colon Rectum 1993:36:559 63.

4. George BD, Williams NS, Patel I, Swash M, Watkins ES. Physiological and histochemical adaptation of the electrically stimulated gracilis muscle to neoanal sphincter function. Br / Surg 1993:80:1342*6.

5. Williams NS. Faecal incontinence In: Keighley MR, Willams NS, eds. Surgery of the anus, rectum and collon. 1st ed. London: WB Saunders, 1993; 516-609.

6. Konsten I, Baeten CG, Spaans. F, Havenith MG, Soeters PB. Follow-up of anal dynamic graciloplasty for fecal continence. World/ Surg 1993:17:404-9.

7. Rius J, Nessim A, Gilliland $R$, el al. Stimulated graciloplasty: main trunk stimulation failures. Changing to intramuscular stimulation: a faesible option. Fechniques Coloproctol 1998;2:109-11.

8. Mawrantonis C, Wexner SD. Stimulated graciloplasty for treatment of intractable fiecal incontinence: critical influence of the method of stimulation. Dis Colon Rectum $1999 ; 42: 497-504$.

9. Korsgen S. Keighley MR. Stimulated gracilis neosphincternot as good as previously thought: report of four cases. Dis Colon Recturn 1995;38:1331-3.

10. Christiansen J, Rasmussen OO, Lindorff-Larsen K. Dynamic graciloplasty for severe anal incontinence. Br J Surg 1998;85:88-91.

11. Sielezneff I, Malotif A1, Banolo DC, Prde A, Douglas S. Dynamic graciloplasty in the treatment of patients with faecal incontinence. Br / Surg 1999;86:61 -5.

12. Madoff RD, Rosen WR, Baeten CG, et al. Safety and efficacy of dynamic muscle piasty for anal incontinence: lessons from a prospective, multicenter trial. Gastroenterology $1999: 116: 549-56$

13. Baeten CG. Spaans F. Fluks A. An implanted neuromuscular stimulator for fecall incontinence following previously implanted gracilis muscle: report of a case. Dis Colon Rectum 1988:31:134-7.

14. Glantz SA. Primer of biostatistics. 3rd ed. New York: McGraw Hill, 1992

15. Geerdes BP, Heineman E, Konsten J Soeters PB. Baeten CG. Dymamic graciloplasty: complications and management. Dis Colon Rectum 1996;39:912-7.

16. Baeten CG, Geendes BP. Adang EM, et al. Anal dynamic graciloplasty in the treatment of intractable lecal incontinence. New Eng / Med 1995;332:1600-5. 
17. Geerdes 3P, Heineman E, Freling G, Keizer HA, Woloszko J, Baeten CG. Vascular and stimulation delays in dynamic musculoplasty. Surgery 1997;121:402-10.

18. Hughes SF, Willams NS. Continent colonic conduit for the treatment of faecal incontinence associated with disordered evacuation. Br/ 5urg 1995;82:1318-20.

19. Versluis PJ Konsten 1, Geerdes B, Baeten CO, Oei KT. Defecographic evaluation of dynamic graciloplasty for fecal incontinence. Dis Colon Rectum 1995;38:468-73. 

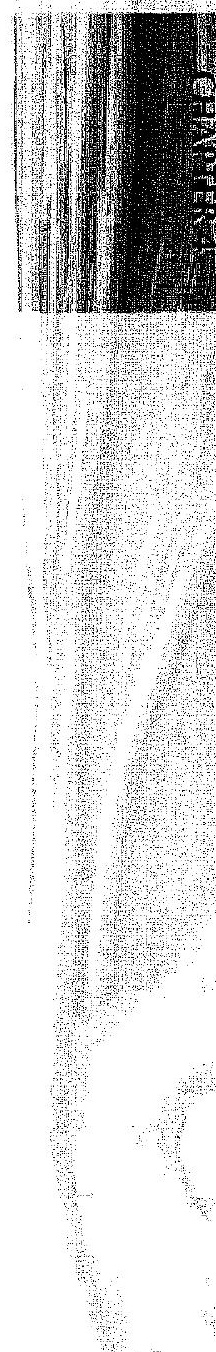
Mart-Jan GM Rongen MD

Frans A Dekker MSC
Erik Heineman $M D$, PhD

Cor CMI Baeten MD, PhD

Bastiaan P Geerdes MD, PhD

\section{Secondary coloperineal pull-through and double dynamic graciloplasty after Miles resection; Feasible, but with a high morbidity.}

Department of surgery, Uniwersity Hospilal Maastricht, Maastricht, the Netherlands

Poster presentation at the meeting of The American Society of Colon and Rectal Surgeons, San Antonio, Texas, May 3 to 8, 1998.

This study was granted by the National Fund for Investigational Medicine (Ministry of Health) the Netherlands

Dis Colon Rectum, 1999. 42(6): p. 776-80 


\section{Secondary coloperineal pull through and double dynamic graciloplasty}

\section{ABSTRACT}

Porpose. [1 th recently patients who underwent abdomingperineal resections (APR) had to cope with a colostomy lor the rest of their lives for songe of these patient fris colostomy was a terrible burden, physically andenentally publications

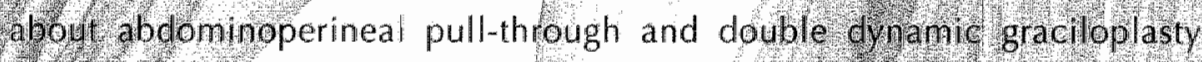
Whicdiately after a Miles resection showed good resultst The purpose of his stidy Was to investigate the procedure as a secondary approach after APR Wethods: In this study 7 patients were evaluated. Mhad hac/ an abdomino perineal resection in the past and proved to have unbearable problems with their stoma. All had a secondary pull-through and double dyanic graciloplasty, mean $8.5(1.1-34.8)$ years after the Miles resection.

Resyls: In five patients continence was regalned No were reversed 10 colostumy due to several complications. Patients who had a siregesflu ourconie

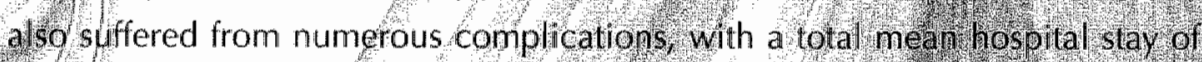

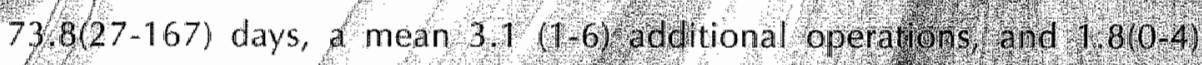
Aradmissions.

Conclusion: Secondary anorectal recristuction after APR S a feasible option. but with a high morbidity. Becayse of this the procedwe Was slopped in the beginning of 1997 . 


\section{INTRODUCTION}

In the past an abdomino-perineal resection (APR) always included an abdominal colostomy. Most patients cope with their colostomy. Of course a stoma disturbs the normal anatomy and some patients have serious problems with this change in body image!.

Cultural and religious aspects can give completely differing view of a colostomy. When a colostomy is performed, some patients consider this as a stigma, leading to e.g. sexual problems ${ }^{2 ; 3}$ or even social isolation. Apart from these emotional problems, about $30 \%$ of all ostomates ${ }^{4}$ have physical problems ${ }^{5}$ like stenosis, prolapse, parastomal hernia or leakage, necessitating reinterventions ${ }^{6}$ in about $10 \%$ of the cases.

Several publications $s^{4 ; 7-13}$ showed successful outcomes on abdominoperineal pull-through operations followed by the construction of a neosphincter with the help of stimulated gracillis muscles in the same session as the APR. These results encouraged us to perform a prospective study in which neoanorectums were created many years after Miles resections.

This study population consisted of a small group of patients whose quality of life was seriously impaired by their colostomy.

\section{PATIENTS AND METHODS}

\section{Patients}

Between June 1991 and March 19977 patients (5 male) with a mean age of 52 (28-71) years were considered eligible for this procedure, having lived with a colostomy for a mean period of $8.5(1.1-34.8)$ years. (Table 1) During this period they had had much discomfort, physically and mentally. Almost all patients had colostomy reconstructions for prolapse, hernia, or infection. Psychological impact was measured twice with a quality of life questionnaire.

All patients, but one, underwent APR for rectal cancer in the past. Patient G underwent APR at the age of 13 for Hirschsprung's disease, after perforation of the anus during dilatation for encopresis. Three patients had received postoperative radiotherapy.

The oncologic status was assessed with colonoscopy, abdominal CT scan and chest X-ray. All were free of recurrence or metastases at the beginning of the anorectal reconstruction. Pre-operative work-up consisted of an electromyogram 
of the gracilis muscles. The score of the questionnaire served as an indicator for the current problems with the colostomy.

All patients gave their informed consent. This study was approved by the medical ethics committee of the Maastricht University hospital.

\section{Operative procedure}

A midline incision was made under systemic antibiotic prophylaxis after bowel preparation. The colostomy was excised and the splenic flexure mobilized. After creation of a passage through the pelvis towards the perineum, the bowel end was sutured to the perineal skin.

Both gracilis-muscles then were mobilized, with preservation of the neurovascular bundle, and led to the perineum. With the exception of patient $A$, both gracilismuscles encircled the colon through a hole in the mesocolon. Both muscles passed along the backside first and were sutured together, in an overlapping fashion, at the myotendinal junctions. There was a 360- degree muscular coverage without usage of the tendons. At contraction the colon would be pulled forward, not only providing closure but also functioning as a puborectal sling. Patient $A$ had the procedure done as described by Cavina and Seccia ${ }^{10-12}$ with one muscle encircling the neo-anus in an alpha configuration and one mimicking a puborectal sling. In all patients a protective illeostomy was constructed.

Before the second operation anal manometry was performed to assess the quality of the voluntary gracilis closure. If good contractions were recorded, after an interval of at least 6 weeks, the pulse-generator and leads were implanted. Having introduced the intramuscular leads into the gracilis muscles near the nerve entries, both electrodes were tunneled subcutaneously to the lower abdomen and connected to an implantable pulse generator (Itrel IIB or Interstim 30230, Medtronic, Kerkrade, the Netherlands), which was placed under the $M$. Rectus Abdominis fascia. Both electrodes were programmed as cathodes, the pulse generator serving as an anode.

In a two months-trainingprogram duty-cycles were increased every 14 days. At these sessions telemetry (Programmer Console 7432ß), Medtronic, Kerkrade, the Netherlands) was performed under manometry control, providing a stimulated pressure increase of at least $20 \mathrm{~mm} \mathrm{Hg}$. Manometry was performed using a KonigsbergiM catheter (Konigsberg Instrument Inc, Pasadena, CA, USA) connected to a polygraph (Synectics Medical, Stockholm, Sweden). After training, the function was tested with defecography. When good closure was achieved, the ileostomy was closed. By then patients were able to switch off stimulation of the graciloplasty with a remote control or a magnet, allowing 
defecation. After this procedure patients were monitored every six months and when necessary, the pulse generator was reprogrammed telemetrically to a higher voltage. Sometimes additional therapy with constipating agents or enema's was prescribed.

\section{RESULTS}

\section{Oncologic results}

All patients, with the exception of patient $G$, had had a curative resection a mean $4.1(1.1-8,8)$ years before the anorectal reconstruction. After a mean follow-up of 6.1 (3.1-9.8) years there were no signs of local recurrence. In patient $\mathrm{B}$ a lung metastasis was discovered six months after the reconstruction, necessitating radiotherapy. The patient died of her metastases three and onehalf years after the reconstruction (Table 1).

\begin{tabular}{|c|c|c|c|c|c|c|}
\hline patient & $\begin{array}{l}\text { Age } \\
\text { (years) }\end{array}$ & Gender & $\begin{array}{l}\text { Astler-Coller } \\
\text { dassiffcation }\end{array}$ & Radiotherapy & $\begin{array}{l}\text { Reconstruction } \\
\text { after APR(years) }\end{array}$ & $\begin{array}{l}\text { Oncologic state at } \\
\text { dast follow-up }\end{array}$ \\
\hline A & 56 & Male & $B 2$ & $\mathrm{NO}$ & $1=11$ & Recurtence free \\
\hline$B$ & 28 & female & $c_{2}$ & yes & 34 & Died of metastases \\
\hline$C$ & 51 & Male & $\mathrm{A}$ & No & 23 & Recumence tree \\
\hline D & 71 & Female & $B)$ & YES & 8.8 & Recurrence free \\
\hline$E$ & 64 & Male & B2 & NO & 2,3 & Recurrence free \\
\hline $\mathrm{F}$ & 43 & Male & $\mathrm{Cl}$ & YES & 69 & Recurrence free \\
\hline G & 48 & Male & $*$ & & 34.8 & \\
\hline
\end{tabular}

Wot an onology patient

Table 1: Background characteristics of patients

\section{Functional results}

Patients visited the outpatient clinic every six months for follow-up with telemetry and manometry monitoring. Simultaneously a regular oncologic follow-up was performed. For continence classification the Williams scale ${ }^{14}$ was used. Score 1 means continent to flatus, liquid and solid stool. Score 2 means incontinent to flatus only. Score 3 includes incontinence for liquid stool. Score 4 refers to occasional and score 5 to frequent loss of solid stool. Scores 1 and 2 were considered to be successful. 


\begin{tabular}{|c|c|c|c|c|c|c|}
\hline Patient & $\begin{array}{l}\text { Years after } \\
\text { reconstruction }\end{array}$ & $\begin{array}{l}\text { Defecalions } \\
\text { per day }\end{array}$ & $\begin{array}{l}\text { Stimulation } \\
\text { Voltage }\end{array}$ & $\begin{array}{l}\text { Resting pressure } \\
\text { (mm Hg) }\end{array}$ & $\begin{array}{l}\text { Stimulation } \\
\text { pressure ( } \mathrm{mm} \mathrm{Hg} \text { ) }\end{array}$ & Result \\
\hline A & 6.0 & 1 & 3.5 & 43 & 98 & Continen with enemas \\
\hline 8 & 2.5 & 1 & 6.5 & 58 & 80 & Continent with enemas \\
\hline $\mathrm{C}$ & 1.6 & $\mathbb{1}$ & 4.2 & 58 & 71 & Consinent with enemas \\
\hline D & 1.0 & & 0.9 & 32 & 89 & Reversed to colostony \\
\hline E & 0.8 & & 1.2 & 56 & 87 & Reversed to colostony \\
\hline 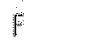 & 1.1 & 2 & 1.5 & 57 & 100 & Continent with enemas \\
\hline$G$ & 0.8 & 2 & 1.6 & 69 & 142 & Continent \\
\hline MEAN & 2.0 & 1.2 & 28 & 53 & 95 & \\
\hline
\end{tabular}

Table 2: Funcional characteristics of patienss

\begin{tabular}{|c|c|c|}
\hline COMPLICATIONS & ACTION & PATIENT \\
\hline \multicolumn{3}{|l|}{ SPECIFIC COMPLICATIONS } \\
\hline Necrotic collon stump & Reoperation & FG \\
\hline Muscular fibrosis (infection), one-sided & Unilateral stimulation & C \\
\hline Fistula & Reoperation & $\mathrm{C}$ \\
\hline Stenosis & Reoperation & ABCG \\
\hline Prolapse & Reoperation & $\mathrm{BD}$ \\
\hline Pelvic hemorthage & Reoperation & A \\
\hline Bowel obstruction caused by adhesions & Reoperation & A \\
\hline Abscess & Drainage & $\mathrm{AO}$ \\
\hline Perforation neoanus & Colostomy & $D E$ \\
\hline \multirow[t]{2}{*}{ Implant infection } & Reimplant (A) & $\mathrm{AD}$ \\
\hline & Explant $(D)$ & \\
\hline Coloculaneous fistula & NPO Total parental nutrition & A \\
\hline \multicolumn{3}{|l|}{ NONSPECIFIC COMPLICATIONS } \\
\hline Fasciadehiscence & Reoperation & $\mathrm{ADG}$ \\
\hline Wrethra and ureterlesions & Reoperation & G \\
\hline Urinary retention & Caheter & E \\
\hline Urosepsis & Antibiotics & $G$ \\
\hline Upper digestive tract bleeding & Medication & A \\
\hline Mesenteric Thrombosis & Reoperation & $\mathrm{D}$ \\
\hline Anastomosisleakage & Reoperation & $\mathrm{D}$ \\
\hline
\end{tabular}

Table 3: Complications after surgery 
Basic pressure was $50.4(32-58) \mathrm{mm} \mathrm{Hg}$. With a mean of $2.7(0.9-6.5) \mathrm{V}$ a mean stimulation pressure of $93.7(71-131) \mathrm{mm} \mathrm{Hg}$ was achieved. Because of complications, only five patients were able to finish the whole procedure, ileostomy closure included. These five had good continence for both liquid and solid stool, albeit with the use of daily enemas. (Table 2).

In two patients comp ications necessitated the construction of a colostomy again.

\section{Complications}

Of all the complications recorded in these patients (Table 3), most of these are related to the operations. One event can have different sequelae. For instance, Patient $D$ had an uneventful procedure until stoma closure. A mesenteric thrombosis occurred two weeks after this operation, necessitating resection of a part of the small bowel. This anastomosis had a leakage. Dehiscence of the laparotomy wound exposed the leads. Infection of the implanted material made removal unavoidable.

Perforation of the neo-amus was an iatrogenic complication. Admission of an enema in one case and catheter placement for defecography in another were the causes of these lesions.

The whole group had a mean in-hospital stay of 74(27-167) days, 3.1(1-6) additional operations and $1.8(0-4)$ readmissions. (Table 4 )

\begin{tabular}{lccc} 
Patient & Days in hospital & Reoperations & Readmissions \\
\hline A & 97 & 5 & 4 \\
B & 30 & 2 & 1 \\
C & 27 & 3 & 2 \\
D & 167 & 6 & \\
E & 44 & 2 & 1 \\
F & 40 & 1 & \\
G & 164 & 4 & 1 \\
MEAN & 80 & 3 & 2 \\
\hline
\end{tabular}

Table 4:

\section{Discussion}

Complications in primary reconstruction have been reported. Cavina ${ }^{10}$ mentioned a percentage of 37 for direct reconstruction-related complications and 10 percent 


\begin{tabular}{|c|c|c|c|c|c|c|c|}
\hline e & $\begin{array}{c}N=81 \\
\text { Cavina } \\
(10)\end{array}$ & $\begin{array}{c}n=15 \\
\text { Santoro } \\
(18)\end{array}$ & $\begin{array}{c}\mathrm{n}=24 \\
\text { Simionsen } \\
(15)\end{array}$ & $\begin{array}{c}\text { n=7 } \\
\text { Mercati } \\
(19)\end{array}$ & $\begin{array}{l}n=23 \\
\text { Elias } \\
(16)\end{array}$ & $\begin{array}{c}n=12 \\
\text { Mander } \\
(13)\end{array}$ & $\begin{array}{c}n=7 \\
\text { Rongen }\end{array}$ \\
\hline \multicolumn{8}{|l|}{ Specific complications } \\
\hline Necrotic colon stump & 4 & & & & 1 & & 2 \\
\hline Perineal infection & 22 & 1 & 4 & & 8 & 2 & \\
\hline Stoma dislocation & 3 & & & & & & \\
\hline Muscular necrosis/fibrosis & 3 & & & & & & 1 \\
\hline Perineal/coloculaneous fistula & 2 & & & & & & 2 \\
\hline Stenosis & 2 & 1 & 2 & & & 2 & 4 \\
\hline Prolapse & 4 & & & & 3 & & 2 \\
\hline Abscess & & & & & & & 2 \\
\hline Tendon impairnient & 1 & 1 & & 1 & & & \\
\hline Pelvic hemornhage & & 1 & & & & & 1 \\
\hline Bowel obstruction & 1 & 1 & & & & & 1 \\
\hline Groin infection & & 1 & & & & & \\
\hline Perforation neo anus & & & & & 1 & & 2 \\
\hline Perineal hernia & & & & & 1 & 1 & \\
\hline Loose graciloplasly & & & & & & 2 & \\
\hline Lead migration & & & & & & 2 & \\
\hline Implant infection & & & & & & 1 & 2 \\
\hline Neurapraxia & & & & & & 2 & \\
\hline Implant failure & & & & & & 1 & \\
\hline
\end{tabular}

Nonspecific complications

\begin{tabular}{|c|c|c|c|c|c|}
\hline \multirow{2}{*}{$\begin{array}{l}\text { Fascia dehiscence } \\
\text { Mesenteric thrombosis }\end{array}$} & \multicolumn{3}{|l|}{3} & & 3 \\
\hline & & & & & 1 \\
\hline Antstomosis leakage & & & & & 1 \\
\hline Urinary retention & 1 & & & 4 & 1 \\
\hline Urosepsis & & & & 1 & 1 \\
\hline Urethra/ureterlesion & & & & & 1 \\
\hline Deep wein thrombosis & 1 & & & & \\
\hline Systemic candidiasis & 1 & & & & \\
\hline Gardiac failune & 1 & 1 & & & \\
\hline Pulmonary event & & 1 & 1 & 3 & \\
\hline GE bleeding & & 1 & & & 1 \\
\hline Acute renal tailure & & & & & \\
\hline
\end{tabular}

Table 5: Complications reported with creation of a perineal colostomy. 
nonspecific complications leading to definite colostomy in 4 of 81 patients. All authors listed in Table 5 performed perineal colostomies and found the direct risks listed 10;13:15-19. Cavina and Secciat ${ }^{10-12}$ used temporary and permanent stimulation with double graciloplasty. Santoro ${ }^{17,18}$ and Simonsen ${ }^{15}$ chose the non-stimulated form. Mercati ${ }^{19}$ also used temporary stimulated gracilis, in contrast to Mander's ${ }^{13}$ chronic low frequency stimulation. Elias ${ }^{16}$ used an auto-transplantation of smooth muscle, taken from the muscularis of the colon, as a neo-sphincter.

Most patients were primarily treated with anorectal reconstruction. Therefore, real comparison with a secondary procedure is difficult. Santoro et al ${ }^{17}$ had only 3 cases of secondary repair. Two of these patients had excellent resulis without events, and one had a fair result after anal stenosis subsequent to a perineal infection, requiring a second operation. Mercati and colleagues ${ }^{19}$ reported that 3 of 7 patients had secondary reconstruction, using temporary stimulation. All cases but one were uneventful, which had tendon detachment. Earlier articles ${ }^{7-9}$, partially covering the patients in this article, mentioned complications caused by colon stump necrosis and stenosis.

Anorectal reconstruction as a secondary procedure induces some difficulties. Immense fibrosis in the presacral area will lead to intraoperative problems in orientation and troublesome tunneling towards the perineum. These problems will only get worse in cases having had earlier radiotherapy.

Postoperatively, this fibrosis will prevent the neorectum from distending on stool arrival, resulting in a higher neorectal pressure.

As proven with anal manometry, the gracilis muscles functioned well, but continence is not the result of sphincter function alone. It also depends on neorectall compliance, sensibility, peristalsis, and stool consistency. These factors are not likely to improve with this kind of anorectal reconstruction.

When performing a procedure for the improvement of quality of life, one will have to take a close look at the balance between risks and results. The complications in this group of patients were serious. Although they were not all directly related to the procedure, we felt that proceeding the study could not be justified. despite good outcome.

If total anorectal reconstruction is performed, it should preferably be done as primary reconstruction. There are, however, patients in which the risks for complications are reduced, for instance in case of a perineal hernia. For other patients the actual colostomy problems are unbearable. In these cases a secondary reconstruction might be appropriate. 
Secondary coloperineal pull-through and double dynamic graciloplasty 


\section{REFERENCES}

1. Orbach $C$, Tallent N. Modification of perceived body and of body concepts. Arch Cen Psychaty. 1965; 12:126-135.

2. Williams NS, Johnston D. The quality of life after rectal excision for low rectal cancar. Br/ Surg. 1983; $70: 460-462$.

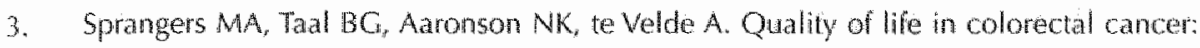
stoma vs. nonstoma patients. Dis. Colon Rectum. 1995; 38361-369.

4. Abercombie IE, Williams NS. Tolal anorectal reconstuction. BN/5urg 1995; 82:4:38-442.

5. Londono-Schimmer EE, Leong. AP. Phillips RK. Life table analysis of stomal complications following colostomy. Dis. Colon Rectum. 1994; 37:916-920.

6. Porter IA, Salwati EP, Rubin RJ, Eisenstat TE. Complications of colostomies. Dis. Colon Rectum. 1989; 32:299-303.

7. Geerdes BP, Zoemulder FA, Baeten CG. Double dynamic graciloplasty and coloperineal pull-through after abdominoperineal resection. Eurl.Cancer. 1995; $31 \mathrm{~A}: 1248$-1252.

8. Geerdes BP, Heineman E, Zoetmulder FA, Adang EMM, Vos E, Baeten CGMI. Double dynamic graciloplasty: an alternative to colostomy after total loss of the anonectum. Ned-Tijoschr-Geneeskd. 1996; 140:773-777.

9. Geerdes BP, Zoetmulder FA, Heineman E, Vos E, Rongen M-1, Baeten CG. Total anorectal reconstruction with a double dynamic graciloplasty after abdomino-perineal neconstruction for tow rectal cancer. Dis.Colon Rectum. 1997; 40: 698-705.

10. Cavina E. Outcome of restorative perineal graciloplasty with simultaneous excision of the anus and rectum for cancer: a ten-year experience with 81 patients. Dis.Colon Rectum. 1996; 39:182-190.

11. Seccia M, Menconi C. Balestri R, Cavina E. Study protocols and functional results in 86 electrostimulated gracilopiasties. Dis. Colon Rectum. 1994; 37:897-904.

12. Cavina $E$, Seccia $M$, Evangelista $G$, et al. Construction of a continent perineal colostomy by using electrostimalated gracilis muscles after abdominoperineal resection: personal technique and experience with 32 cases. 1tal. $1.54 \mathrm{~g}$. $5 \mathrm{ci}$. 1987; 17:305-314.

13. Mander BJ, Abercrombie fF, George BD, Willams NS. The electrically stimulated gracilis neosphincter incorporated as part of total anorectal reconstruction after abolominoperineal excision of the rectum. An Surg. 1996; 224:702-711.

14. Willams NS, Patel J, George BD, Hallan RI, Watkins ES. Dewelopment of an electrically stimulated neoanal sphincter. Lancet. 1991; 338:1166-1169.

15. Simonsen OS, Stolf NA, Aun F, Raia A, Habr-Gama A. Rectall sphincter reconstruction in perineal colostomies afrer abdominoperineal resection for cancer. Brl.Surg. 1976; 63:389-391. 
16. Flias $D$, Lasser P, Leroux A, Rougier P, Comandella MG, Deraco M. Pseudo-continent perineal colostomies after amputation of the rectum for cancer in French. Castroenterol.Cin. Biol. 1993; 17:181-6.

17. Santoro E, Tirelli $C$, Scutari $F$, et al. Continent perineal colostomy by transposition of gracilis muscles: technical remarks and results in 14 cases. Dis. Colon Rectum. 1994; 37 suppl:573-80.

13. Santoro Eantoro R. Perineal reconstuction with continent colostomy after the Miles operation, Sermin Surg. Oncol. 1994; 10:208-16.

19. Mercati $U$, Trancanell $V$, Castagnoli GP, Marioti $A$, Ciaccarini $R$. Use of the gracilis muscles for sphincteric construction after abdominoperineal resection: technique and preliminary results. Dis. Colon Recum. $1991 ; 34$ : 


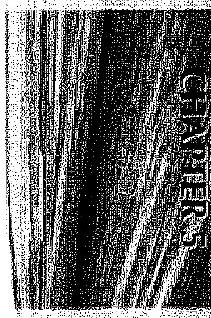


Mart-Jan GM Rongen MD Regina GH Beets-Tan MD, PhD*
Walter H Backes PhD.* Cornelius GMI Baeten MD, PhD

\section{The effects of high field strength MRI on electrodes and pulse generator in dynamic graciloplasty}

Departments of surgery and radiology* University hospital Maastricht, Maastricht, the Netherlands.

Colorectal Dis, 2004. 6(2): p. 113-6 


\section{ABSTRACT}

Purpose:Dynamic graciloplasty is a treatment for intractable fecal incontinence. A gracilis muscle is transposed around the anus and stimulated with an implanted pulse generator (IPG). This in vitro study was designed to determine the safety of MRI in patients with implanted electrodes and pulse generators for dynamic graciloplasty.

Methods: Temperatures were measured with fiberoptic probes around the devices in a cadaver model current was measured with an oscilloscope connected to electrodes and IPG. Movenent and IPG parameter selting were observed before, during and after testing.

Resuls: Minor temperature increase under $1{ }^{\circ} \mathrm{C}$ was observed around the electrodes. Amplitudes measured were within the range of -1 and +1 Volt. No movement or changing of IPG parameters was noted.

Discussion. Charages noted are well within physiological ranges. Dynamic graciloplasty is net a contraindication for high field strength MRI. 


\section{INTRODUCTION}

Dynamic graciloplasty has shown good results in the treatment of selected patients with intractable fecal incontinence ${ }^{1,2} \mathrm{~A}$ gracilis muscle is transposed around the anal canal and can be stimulated with an implantable pulse generator (IPG). This IPG is placed in the lower abdomen underneath the sheath of the rectus abdominis muscle and connected with electrodes for gracilis intramuscular or epineural ${ }^{3}$ nerve stimulation. Stimulation of this neosphincter will close the anus to prevent leakage of stool. With a remote control or a magnet stimulation can be switched off to allow defecation.

The same technique is also used in patients with rectal cancer, after abdominoperineall resection. Here the descending colon is pulled through to the perineum as a perineal colostomy. A total anorectal reconstruction is performed with a one-sided or double sided dynamic graciloplasty ${ }^{4-7}$.

Patients with dynamic graciloplasty may require pelvic MRI's, for example, to evaluate the graciloplasty ${ }^{8}$, to exclude complications such as perineal sepsis or to exclude local recurrence after treatment of a primary rectal cancer.

Untill now potential adverse effects of the magnetical field of the MRI machine on the IPG have precluded these patients from MRI examination.

To our knowledge only one study ${ }^{9}$ has reported the use of MRI in patients with dynamic graciloplasty and the results showed no harmful side-effects of the magnetic field on the implanted material. However this study was performed at low field strength.

There are four problems that may arise when exposing patients with these implantable devices to MRI. The electromagnetic radiofrequency fields can cause development of heat ${ }^{10}$ and the induction and change of current. The static magnetic field might cause the material to move within the body. All these forces could also cause malfunctioning of the device itself.

Our purpose was to evaluate the feasibility of high field strength MRI in patients with dynamic graciloplasty. We therefore conducted an in vitro study to determine heat, movement and current development and influences on parameter settings of the IPG.

\section{Material ANd Methods}

In order to measure temperature rise an IPG and electrodes were implanted in 
a cadaver porcine abdominal wall. The IPG (Interstim®, Medtronic, Kerkrade, the Netherlands) and two $35 \mathrm{~cm}$ platinum iridium electrodes (model 43003513, Medtronic, Kerkrade, the Netherlands) were placed in the subcutaneous fat. The bare surfaces of the electrodes were implanted in the rectus abdominis muscle, mimicking implants in patients. Fiberoptic probes were placed at the $I P G$, at the bare surfaces and at five locations in the course of the electrodes, at the beginning, at quarter-, mid, threequarter-distance and at the end. One probe measured air temperature in the MRI room. Temperature was recorded with the fluoroptic reading device Luxtron 790 (Luxtron Corporation, Santa Clara, CA, USA), collecting data with a PC. At several MRI protocol settings tests were performed.

To assess induction currents an oscilloscope (TDS 420, Tektronix, Heerenveen, the Netherlands) was connected to the electrodes and the IPG with a coaxial copper wire $(50 \Omega)$ as extension cable, thus minimizing induction of currents by the measurement cables themselves. The oscilloscope was placed outside the MRI room. To assess the influences of the MR machine on the extension cables the measurements were repeated with only the extension cables in situ and without the IPG and electrodes.

During the tests possible movement of the IPG and the electrodes was observed. Pulse generator and electrodes were also placed in the functioning MR scanner, unattached, to rule out restraining by the mass of the dummy.

IPG settings were checked with telemetry before and after each experiment. Telemetry was performed with a console programmer (Model 7432®, Medtronic, Kerkrade, The Netherlands). Different amplitudes were programmed to mimic settings in patients, 0 Volt, 3 Volt (just above the mean amplitude in dynamic graciloplasty) and also the maximal amplitude of 10.5 Volt. Magnet switching of the IPG was disabled.

None of the equipment used, except the IPG, electrodes and extension cables, contained metal, which itself could induce heat and current.

All measurements were performed with a 1.5 Tesla MR scanner(Gyroscan $B$, Philips ACS-NT release 6.2 .1 , maximal gradient strength $23.0 \mathrm{mT} / \mathrm{m}$, rise time $0.2 \mathrm{~ms}$, slew rate $105 \mathrm{~T} / \mathrm{m} / \mathrm{s}$, Philips Medical Systems, Best, The Netherlands). The test phantom was placed in the centre of the bore of the MR scanner, which was operated at a maximal power of $3.9 \mathrm{~W} / \mathrm{Kg}$. Sequences used were a T1 weighted, 2D, turbo spin echo (T1W TSE: TR/TE $612 / 15 \mathrm{~ms}, 5$ turbo factor, 3 mm slice thickness, $0.3 \mathrm{~mm}$ gap, 8 signal averages, $383 \times 512$ matrix, $20 \mathrm{~cm}$ field of view (FOV), $0.6 \mathrm{~mm}$ woxel size, $9.0 \mathrm{~min}$ acquisition time) and a T2 


\section{$3.9 \mathrm{~W} / \mathrm{Kg}$ ANPLITUDE}
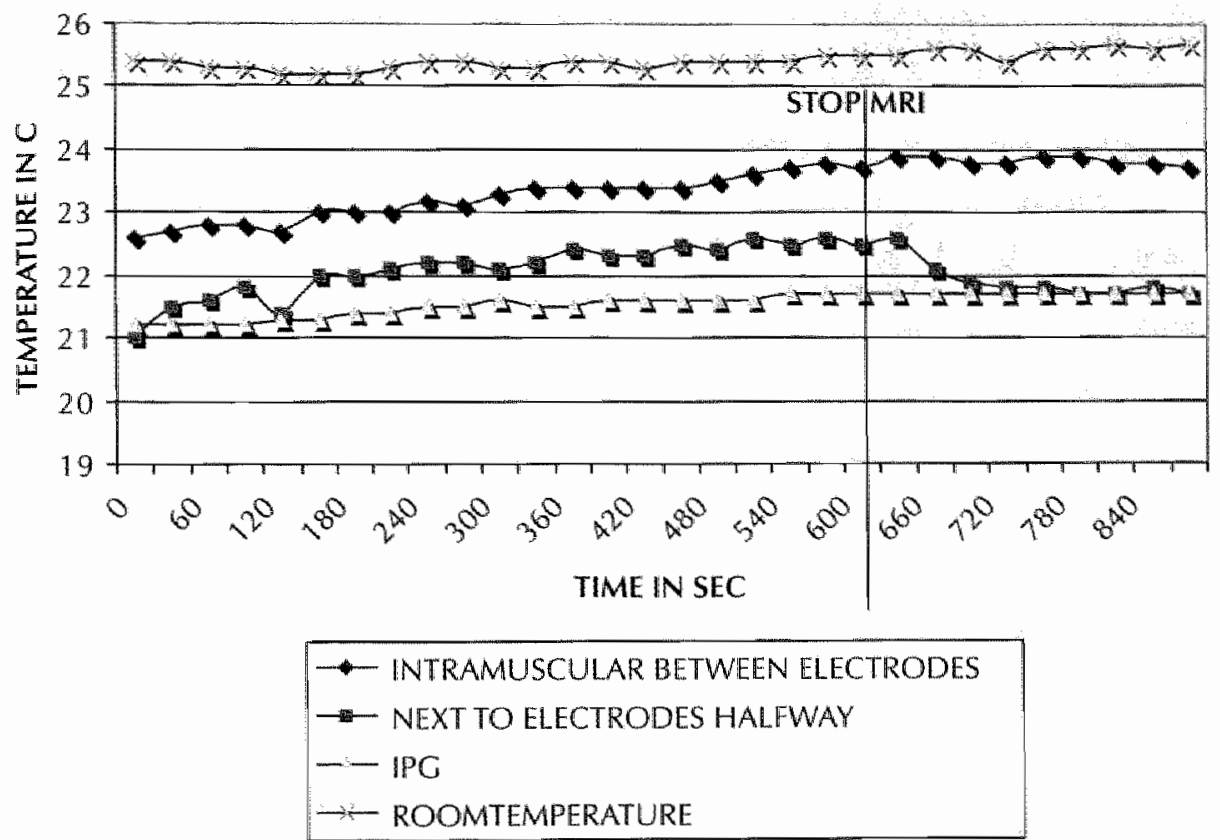

The induction of temperature by MRI on electrodes and IPG used in dynamic graciloplasiy in the most unfavorable conditions.

Figure 1:

weighted, 2D, turbo spin echo (T2W TSE: TR/TE $3427 / 150 \mathrm{~ms}, 25$ turbo factor, $3 \mathrm{~mm}$ slice thickness, $0.3 \mathrm{~mm}$ gap, 8 signal averages, $175 \times 256$ matrix, $20 \mathrm{~cm}$ FOV, $2.6 \mathrm{~mm}$ voxel size, $6.5 \mathrm{~min}$ acquisition limel. Both types of acquisition were obtained in axial plane.

\section{RESULTS}

Increase in temperature, under expected worst possible conditions $13.9 \mathrm{~W} / \mathrm{Kg}$ amplitude $10.5 \mathrm{Volt}$ ), was minimal compared to room temperature. At the distal side of the electrode, the bare surface (potentially most harmful side in patients, 
close to the nerve in the gracilismuscle) temperature rose from 22.6 to $23.9^{\circ} \mathrm{C}$ with a room temperature well over $25^{\circ} \mathrm{C}$ (Figure 1$)$. In all other settings (e.g. different MR and amplitude settings) and also after making loops in the electrodes to increase the reception for electromagnetic influences, the temperature rise was even less notable.

Amplitude measured with the oscilloscope was within the range of -1.0 and +1.0 Volt, when IPG and electrodes were connected to the extension cables. These amplitude values remained unchanged even when the measuring cables were short-circuited and IPG and electrodes were removed.

No movement of any of the devices was noted during the tests. A torque force could be felt when the IPG was brought into the static field in a perpendicular fashion. This force could easily be overcome without applying much strength. During the tests all IPG's were positioned parallel to the $\mathrm{B}_{\mathrm{o}}$ field strength of the magnet.

IPG parameters remained unchanged after all tests.

\section{Discussion}

Pulse generators and electrodes have been used in the field of cardiology, neurology, urology and colorectal surgery. There are controversial potential adverse effects of the MR machine on implanted device. ${ }^{11,12,13}$. Onlly one in vitro study has reported on the adverse thermal effects of a pulse generator and electrodes in a MRI scamner ${ }^{14}$.

In contrast to their results temperature increase shown in our study was minimal. Part of the temperature increase could be attributed to adaptation to environment temperature, as the temperature of our test material was lower than room temperature. One could argue that testing should have been done at normal body temperature to rule out any further increase in peri-electrode temperature within the range of possible hazard. However with normal body perfusion the electrodes would rapidly cool down if any increase in temperature would occur at all.

In contrast to Tronnier et al, who found an induction of up to 5.5 Volt in their model ${ }^{14}$, we observed an induction of maximal 1 Volt with our study model. Given the fact that testing short circuited testing cables also created amplitudes in the range of -1 and +1 Volt, it is more likely that the amplitudes measured in this study are caused by the measuring equipment rather than by the implant itself. But even if these amplitudes reflect real voltages from the implanted material, no harm can be done to the patients. Normal stimulation in dynamic 
graciloplasty occurs at a mean amplitude of 2.3 Volt. When the stimulation is programmed on 0 Volt before the start of the MR investigations the worst thing that could happen is the induction of 1 Volt. Generally, this is below the threshhold of activation of the gracilis muscle. In case of a reduced threshold, which would be below 1 Volt, only a weak harmless contraction could be expected. High field strength MRI therefore seemed to be well tolerated by the equipment used in dynamic graciloplasty. Our study shows only slight influences with regard to heat and current, but these are well within physiological limits.

The IPG is always implanted beneath the sheath of the Abdominal Rectus muscle and therefore always in a parallel alignment within the static magnetic field. Even after escaping from this created pocket, the force would not be sufficient enough to cause migration of the IPG in a MR field.

In 3 patients with a dynamic graciloplasty in our clinic a MRI was necessary to investigate the cause of perineal pain. After disabling magnet-switching and reducing stimulation amplitude to 0 Volt, they underwent the investigation. No sense of movement, heat or stimulation was noted by the patient during the imaging. IPG parameters were unchanged after the procedure.

\section{Conclusion}

Dynamic graciloplasty is not a contra indication for high field strength MRI, providing that magnet switching is disabled and stimulation turned off.

\section{ACKNOWLEDGEMENT}

We wish to thank E L.emaire, technician at the department of radiology of the University hospital Maastricht for all his effort. 
The effects of high field strength MRI on electrodes and pulse generator 


\section{REFERENCES}

1. Baeten CG, Geerdes BP, Adang EM, Heineman E, Konsten, Engel $C$, et al. Anal dwamic graciloplasty in the treament of intractable fecal incontinence. N.Engl.M.Med. 1995: $332: 1600-1605$.

2. Seccia M, Menconi C, Balestri R, Cavina E. Study protocols and functional results in 86 electrostimulated graciloplasties. Dis. Colon Rectum 1994; 37:897-904.

3. Williams NS, Patel I, George BD, Hallan RI, Watkins ES. Dewelopment of an electrically stimulated neoanal sphincter. Lancet 1991; 338:1166-1169.

4. Geerdes BPr Zoetmulder FA, Heineman E. Vos EJ, Rongen MI. Baeten CG. Total anorectal reconstruction with a double dynamic graciloplasty after abdominoperineal reconstruction for low rectal cancer. Dis. Colon Rectum 1997; 40:698-705.

5. Rongen MJGM, Dekker FA, Geerdes BP. Heineman E, Baeten C. Secondary coloperineal pull-through and double dymamic graciloplasty after Miles resection; feasible, but with a high morbidity. Dis. Colon Rectum 1999; 42:778-781.

6. Cawina $\mathrm{E}$, Seccia $M$, Evangelista $G$, Charugi $M$, Bucciant P. Tortora A, el al. Perineal colostomy and electrostimulated gracilis "neosphincter" after abdominomerineal resection of the colon and anorectum: a surgical experience and follow-up sttudy in 47 cases. Int. Colorectal Dis. 1990; 5:6-11.

7. Williams NS, Hallan RI, Koeze TH, Watkins ES. Construction of a neorectum and neoanal sphincter following previous proctocolectomy. Br./Surg. 1989; 76:1191-1194.

8. Konsten 1, Baeten CG. Havenith MG. Oei TK. Evaluation of gracilis muscle transposition for fecal incontinence with magnetic resonance imaging. Eur. Radiol. $1993: 16: 190-194$.

9. Cavallaro A, Fellner $F$, Matzel KE, Stadelmaier U, Rupprecht T, Bowing B, el al. Lowfield magnetic resonance imaging of the petwis in patients with anal dynamic graciloplasty: initial experience. MACMA. 1998:7:179-183.

10. Achenbach 5, Moshage W, Diem B, Bieberle T, Schbgilla V, Bactmann K. Fifects of magnetic resonance imaging on cardiac pacemakers and electrodes. Am. Heart / 1997; $134: 467-473$.

11. Gimbel JR, Johnson D, Levine PA, Wilkoff BLRA. Sale performance of mangetic resonance imaging on five patients with permanent cardiac pacemakers. Pace Pacing olin. Fectrophysiology 1996; 19913-919.

12. Inbar $S$, Larson I. Burt T, Mafee M, Ezri MD. Case report: nuclear magnelic resonance imaging in a patient with a pacemaker. Am.J.Med Sci. 1993; 305:174-175.

13. Liem LA, wan Dongen VC. Magnetic resonance imaging and spiral cond slimulation systems. Pain 1997; 70:95-97.

14. Tronnier VM, Staubert A, Hahnel S, Sarem AA. Magnetic resonance imaging with implanled neurostimulators: An in vitro and in vivo study. Neurosurgery 1999; 44:1 $18-125$. 
15. Beets-Tan RGH, Beets GL, Gerritsen van der Hoop $A$, Borstlap ACW, Boven V M, Rongen MMCM, et al. High resolution magnetic resonance imaging of the anorectal region without an endocoil. Abdom /maging 1999 Nov-Dec;24(6):576-81; discussion 582.4 


$$
\text { ? }
$$




\section{Cecal access for antegrade colon enemas in medically refractory slow-transit constipation. A prospective study.}




\section{ABSTRACT}

Purpose. The current surgical treatment for therapy-resistant slow-transit constipation consists of either subtotal colectomy or ileostomy. This prospective stidy was performed to examine the creation of an access enabling antegrade enemas of the colon as an alternative to these interventions. Development of symproms associated with constipation was also a study subject.

M.thods. 12 patients with median defecation frequency of once a week were evaluated fre-eperatively, using marker-transit studies, defecography, manometry and colonosegpy. All patients stbsequently received an enema access, placed in the lower inght abdomen. The appendix (available in 7 cases) was laparoscopically fixed to the abdominal wall and served as a stoma, a procedure that required a comversion in 1 case 1 in 5 previously appendectomized cases the terminal part of The lleum was transsected, its distal side was fixed to the abdominal wall to serve as a stoma and the proximal side was anastomosed to the ascending colon.

Qualiy of life-assessment was included. This consisted of Nottingham Health Pirfle (N/1), State Trail Anxiety Inventory (STAI) and Zung tests, as well as disease specific questions. Besides perioperative and out-patient evaluations, patients yere asked fir and scored on constipation associated symptoms.

Resilts. 12 patients ( 8 female, 4 male), mean age 43 (17-66) years, were treated. Using various enema regimes, frequency of defecation (median 1 daily) without major conplications was established. In 4 cases, a subtotal colectomy was required In the long run. Two of these 4 patients needed an ileostomy afferwards for persisting symptoms. State Trait Anxiety liventery and ZUNG results improved, as did several associated symptoms. Overall constipation score dropped from median 21,5 to:5,5.

Conclusion: Cecal access for antegrade colon enenas in medical therapy resistant slow-transit constipation is a minimally invasive procedure with promising results. In case of failure further surgery is not compromised by this procedure. 


\section{INTRODUCTION}

Constipation is a disorder with a great impact on daily life. As insight on motility of the gut grows, therapy for this problem equally evolves. Conservative methods of treatment by diet, medication, biofeedback, or colon irrigation are the main options in constipation. Nevertheless, there are patients that end up in emergency wards with bowel obstruction.

With the use of marker colon transit studies and defecography, functional constipation can be divided in normal or slow transit type either with or without pelvic floor dysfunction. Pelvic floor dysfunction, a much-discussed diagnosis, is treated by biofeedback therapy although newer modalities of treatment are subjects of investigation. Normal transit constipation is regarded a form of irritable bowel syndrome that requires medical treatment and should indicate surgery'.

For end stage slow-transit constipation there are two surgical options, ileostomy or (sub)total colectomy. An ileostomy, however, can have serious implications for a patient's quality of life. In a colectomy an ileorectal anastomosis gives the best results ${ }^{2}$.

However, constipation is more than just a deranged defecation frequency. Associated symptoms as bloating, abdominal pain, straining, are equally important for a patient.

Despite increased defecation frequency, these symptoms will not necessarily disappear after surgery ${ }^{3,4}$.

The colon thas often been irrigated in a retrograde way. There are experiences with antegrade irrigation of the colon as first described by Malone et al ${ }^{5,6}$ who used the appendix as an access to the cecum. This trealment for fecal incontinence was first used in children, followed by studies that used mixed populations and indications ${ }^{67}$. This procedure was described as a treatment for constipation ${ }^{8}$. However, a prospective study on this method for slow-transit constipation exclusively was never performed.

Previous experiences with cecal access surgery showed several problems with the ostomy and the irrigation itself $f^{6,9}, 10$. Stenosis, prolaps and necrosis of the stoma were reported, as were infections, dehiscence and hypergranulation. Leakages of mucus and irrigation fluid were major problems.

The ideal cecal access would be free of leakage and constructed with minimal invasive" "surgery. This therapy should also give improvement in constipationassociated symptoms. These were the criteria for a prospective study at our clinic. 
Score

\begin{tabular}{|c|c|}
\hline \multicolumn{2}{|l|}{ Freguency of bowel movements } \\
\hline $1-2$ linies per 12 days & 0 \\
\hline 2 times per week & 1 \\
\hline Orce per week & 2 \\
\hline Les than once per wreek & 3 \\
\hline Les than once per month. & 4 \\
\hline \multicolumn{2}{|l|}{ Difficulty: painfuil exacuation effort } \\
\hline Ut Never & 0 \\
\hline Rarely : & 1 \\
\hline sometimes & 2 \\
\hline Usually & 3 \\
\hline Always & 4 \\
\hline \multicolumn{2}{|c|}{ Completeness feeling incomplete evacuation } \\
\hline Never & 0 \\
\hline Rarelyx & 1 \\
\hline Sornetimes & 2 \\
\hline Usually & 3 \\
\hline Always & 4 \\
\hline \multicolumn{2}{|l|}{ Pain: Abdominal pain } \\
\hline Newer & 0 \\
\hline Rarely & 1 \\
\hline Sometimes & 2 \\
\hline Usually & 3 \\
\hline Always & 4 \\
\hline \multicolumn{2}{|c|}{ Time: minutes in lavatory per attempt } \\
\hline Less than 5 & 0 \\
\hline $5 \% 10$ & 1 \\
\hline $10-20$ & 2 \\
\hline $20-30$ & 3 \\
\hline More than 30 & 4 \\
\hline \multicolumn{2}{|l|}{ Assistance: lype of assistance } \\
\hline Without assistance & 0 \\
\hline Stimulalive laxatives & 1 \\
\hline Digital assistance or enema. & 2 \\
\hline \multicolumn{2}{|c|}{ Failure: unsuccessful attempts for ewacuation per 24 hours } \\
\hline Newer & 0 \\
\hline 1.3 & 1 \\
\hline $3-6$ & 2 \\
\hline $6-9$ & 3 \\
\hline More than 9 & 4 \\
\hline \multicolumn{2}{|l|}{ History: duration of constipation (yr) } \\
\hline 0 & 0 \\
\hline 1.5 & 1 \\
\hline $5-10$ & 2 \\
\hline 10.20 & 3 \\
\hline More than 20 & 4 \\
\hline
\end{tabular}

Mini inum score, 0, Maximum score, 30 ?

Table 1: Fu Laderdale constipation scoring system ${ }^{12}$ 


\section{Patients and methods}

Patients with end stage constipation who were included in this prospective study were refractory to medical treatment. All patients had used laxatives, fiber rich diets and colon irrigation. Marker studies must have shown prolonged colon transit time. If defecography showed signs of pelvic floor dysfunction, biofeedback therapy was given first. Anal manometry was performed routinely. Electromyography and colonoscopy, with or without biopsy, were performed on indication only.

Exclusion criteria were heart failure, due to the extra fluid that has to be administered, an age under 15 years old, and suspected incompetence regarding stoma care or irrigation method.

The patients' histories were noted very accurately regarding not only defecation frequency but also the associated symptoms and all the criteria used in the Cleveland Clinic constipation scoring ${ }^{12}$ system (Table 1). All patients signed an informed consent. This study was approved by the medical ethics committee of our hospital.

\section{Operation}

When present, the appendix was used for the creation of the cecal access. This was done laparoscopically if feasible. To prevent leakage the appendix was obliquely exteriorized through the abdominal wall through the trocard opening (Figure 1), thus allowing abdominal wall pressure to close the appendicostomy.

In patients without an appendix an Iron Grid incision was made and the terminal ileum was divided $8-10 \mathrm{~cm}$ from the ileocecal valve. The distal end was sutured flush to the skin, the proximal end was reanastomosed to the ascending colon in an intussuscepted fashion (Figure 2). The old ileocecal valve should prevent leakage of irrigation fluid.

In all patients, an urinary catheter was placed in the cecum and irrigations were started the next day, using tap water. $(200 \mathrm{ml}$ twice a day). After 5 days patients were discharged with the catheter in site and were able to irrigate. Amount of water and frequency of irrigations was expanded on patient's individual need with a maximum of 2,0 liters per day.

Outpatient visits were on a once a week basis until 4 weeks. At this visit the catheter was removed and patients were taught how to apply the catheter themselves when needed. After this patients were scheduled for follow-up visits 


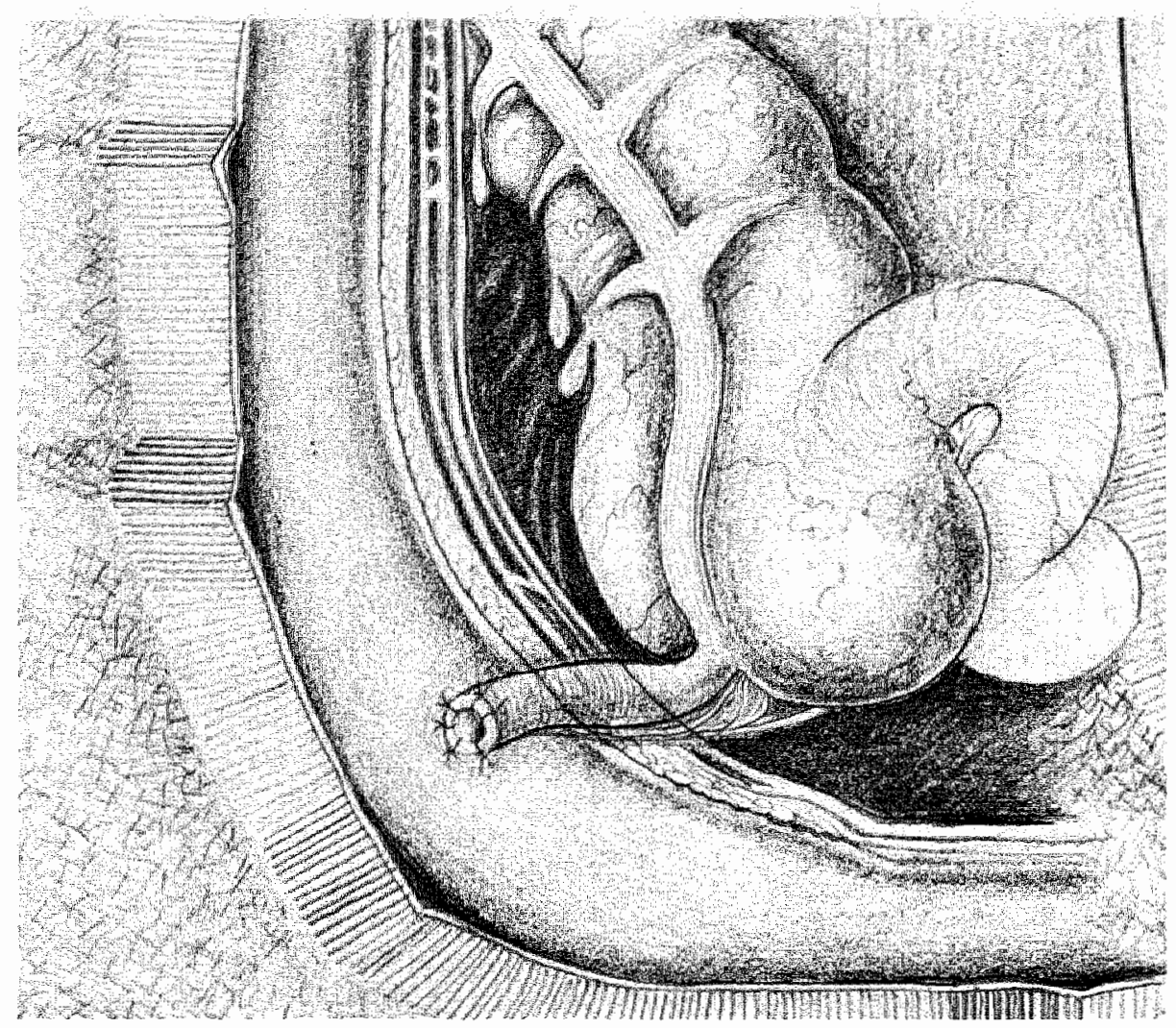

Figure 1: Appendicostomy

at 3 and 12 months after surgery. At every visit history was taken, the stoma was checked and complications were recorded.

\section{Quality of life}

For this study three questionnaires were used. The Nottingham Health Profile part 1, intended to measure health in six specific areas, was combined with the Zung self rating depression scale and the State Trait Anxiety Inventory (STAl). On disease specific questions patients had to score on a scale from to 10 , high scores representing unfavorable states.

\section{Statistical analyses}

All data are expressed as medians. Wilcoxon signed ranks for non parametric data were used for analyses with the use of SPSS 8 (SPSS Inc, Chicago, II, USA). A P-value of 0.05 or less was considered to indicate statistical significance. 


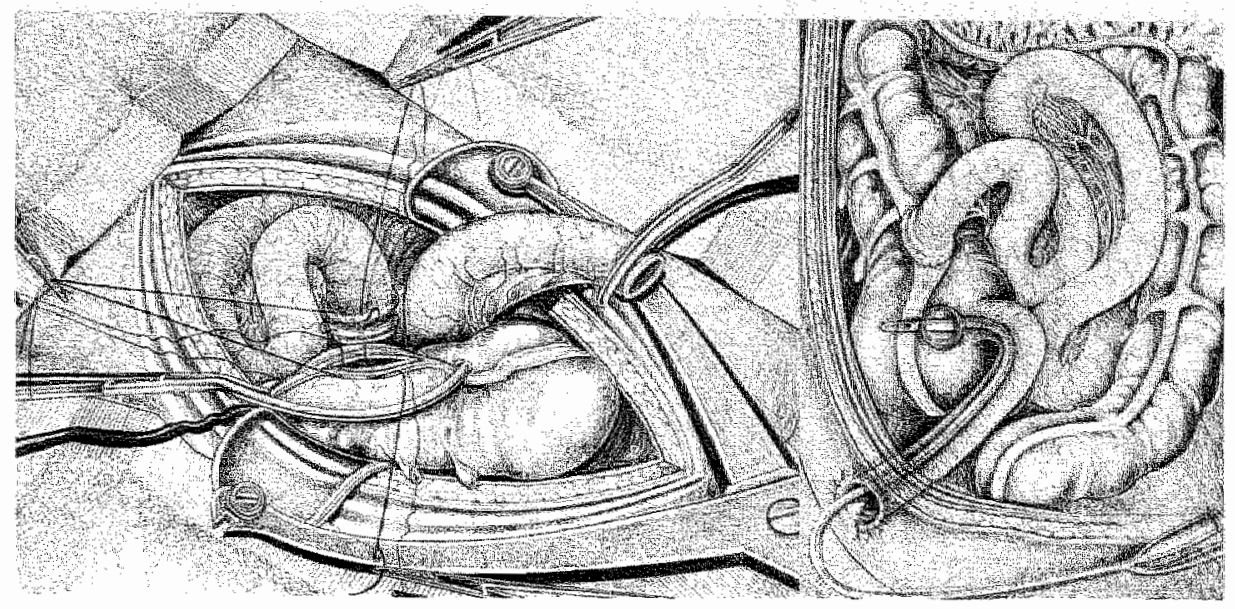

Figure 2: The ileocecostomy

\section{RESLITS}

12 patients were included, 8 females and 4 males with a median age of 42,9 (17-66) years. Constipation was caused by chronic obstructive pulmonary disease medication once, and hernia nuclei pulposi twice. In 9 patients constipation was idiopathic and had a juvenile onset. In their medical history 4 patients had had rectopexies, one a resection of the sigmoid and one a dynamic graciloplasty for fecal incontinence. On defecography two patients had sign of pelvic floor dysfunction for which they received biofeedback therapy and one had an enterocele that required a rectopexy. Median defecation frequency was 1.0 times per week, with a very solid consistency.

In 7 patients the appendix was used for the access creation by laparoscopy, though one patient needed conversion. In the other patients the illeum was used for cecal access.

After a median follow-up of 532 (352-694) days, 8 out of 12 patients were considered successful. Three patients underwent subtotal colectomy with ileorectal anastomosis; one is on the waiting list for this procedure. In two of them there were still evacuation problems, despite the subtotal colectomy. An ileostomy was necessary in these 2 patients, and one of them still has fecal impactions that require enemas through the ileostomy. 


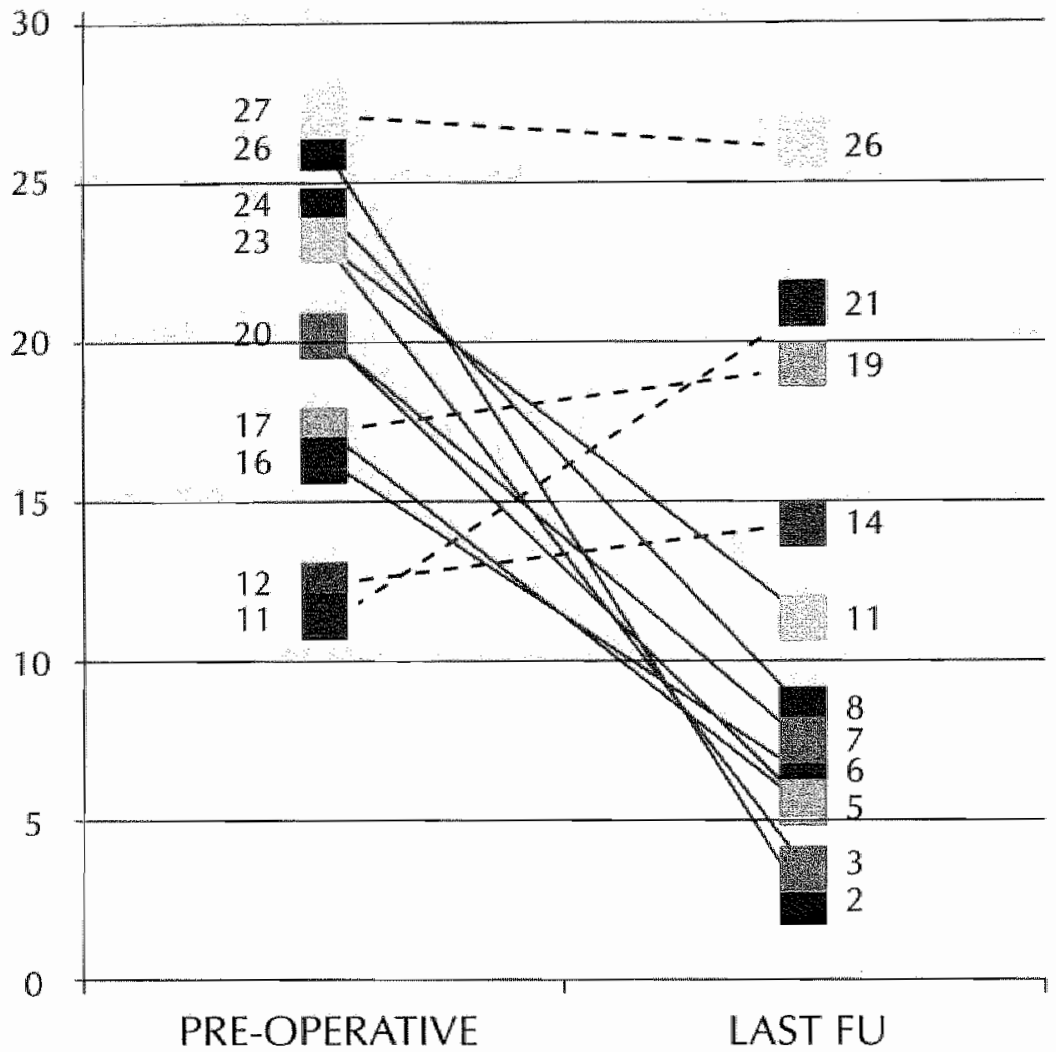

Interupted line represents unsuccessful patients, uninterrupted line represents successful patients

Figure 3. Individual changes in fot Luderdale constipation scoring system ${ }^{12}$

Overall results show a significant decrease in constipation scores (Table 2 . Figure 3) and the median defecation frequency is now 7,0 times per week. Irrigation was done a median 2,0 (0.29-5.0) times per day with median 500 (150-1000) $\mathrm{ml}$ tap water and it required 15 (2-60) minutes per procedure. Constipation associated symptoms in patients with an increased defecation frequency also showed significant improvement regarding rectal pain, incompleteness of defecation and the use of laxatives or manual evacuation. Changes in presence of abdominal pain or bloating were not significant. 


\begin{tabular}{|c|c|c|c|}
\hline 3 & Pre operative & 12 months & $p=$ \\
\hline Abdominal pain & 1,00 & 0,00 & 0,102 \\
\hline Bloating & 1,00 & 1,00 & 0,157 \\
\hline Fafulience & 0,50 & 1,00 & 0,317 \\
\hline trcomplate evacualion & 1,00 & 0,00 & $0,008^{*}$ \\
\hline Use of laxatives & 1,00 & 0,00 & $0,008^{*}$ \\
\hline Manual evacuation & 1,00 & 0,00 & $0,025^{*}$ \\
\hline Rectal pain & 1,00 & 0,00 & $0,025^{*}$ \\
\hline Straining & 1,00 & 1,00 & 0,083 \\
\hline Trme in minutes & 15,00 & 5,00 & $0,017^{*}$ \\
\hline Defecations per week & 1,00 & 7,00 & $0,018^{*}$ \\
\hline Fl_auderdalescore & 21,50 & 5,50 & 0,012 \\
\hline
\end{tabular}

Statistically significant

Table 2. Results for associated symptoms, defecation frequency and time and constipation score

\section{Quality of Life}

Scores in STAI and Zung were elevated pre-operatively compared to standard and remained elevated. Nevertheless they significantly improved in successfully treated patients. NHP levels, also elevated at baseline measurement in most scales, had a tendency to decrease to normal levels, though this never reached statistical significance (Table 3).

The scores of the disease specific questions (Table 4) seemed to go down, but only as far as bloating is concerned is this significant.

\begin{tabular}{llllll}
\multicolumn{1}{c}{} & Pre operative & $P_{1}=$ & 3 months & 12 months & $P_{2}=$ \\
\hline STAl & 51,00 & 0,176 & 49,00 & 45,50 & $0,046^{*}$ \\
ZUNG & 50,00 & 0,201 & 42,50 & 43,00 & $0,017^{*}$ \\
NHP & & & & & \\
Mobillity & 21,30 & 0,225 & 15,85 & 11,20 & 0,08 \\
Pain & 74,72 & 0,08 & 19,10 & 10,43 & 0,225 \\
Energy & 63,20 & $0,043^{*}$ & 0,00 & 24,00 & 0,068 \\
Sleep & 72,74 & 0,273 & 67,14 & 67,14 & 0,144 \\
Social isolation & 19,36 & 1 & 0,00 & 0,00 & 0,465 \\
Emotional reaction & 55,85 & 0,249 & 16,76 & 26,05 & 0,463 \\
\hline
\end{tabular}

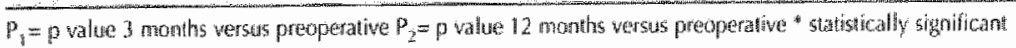

Table 3: Resuls for quality of life tests 


\begin{tabular}{|c|c|c|c|c|c|}
\hline & Pre operative & $p 1=$ & 3 months & 12 months & $p^{2}=$ \\
\hline $\begin{array}{l}\text { How often do you have } \\
\text { abdominal pain (never every day) }\end{array}$ & 5,00 & 0.144 & 3,00 & 5,00 & 0,892 \\
\hline $\begin{array}{l}\text { How much are you bothered by your: } \\
\text { current diet? not at all unbearable) }\end{array}$ & 2,00 & 0,655 & 1,00 & 1,00 & 0,066 \\
\hline $\begin{array}{l}\text { How offen do you have } \\
\text { a bloated sensation? lnever-every day) }\end{array}$ & 9,00 & 0,290 & 7,00 & 5,00 & $0,027^{\prime \prime}$ \\
\hline $\begin{array}{l}\text { How often are you nauseous? } \\
\text { (never every clay) }\end{array}$ & 5,00 & 0,785 & 3,00 & 3,00 & 1,000 \\
\hline $\begin{array}{l}\text { How would you define your } \\
\text { current lieal the (very healthy very lly) }\end{array}$ & 6,00 & 0,892 & 5,00 & 5,00 & 0,497 \\
\hline $\begin{array}{l}\text { How much are you bothered } \\
\text { by your stoma? (not at all tumbearable) }\end{array}$ & & & 3,00 & 4,00 & \\
\hline $\begin{array}{l}\text { How much are you bothered } \\
\text { by your enemas (not at allinbearable) }\end{array}$ & & & 4,00 & 3,00 & 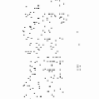 \\
\hline $\begin{array}{l}\text { How would you define your satisfaction } \\
\text { with regards to this procedune? }\end{array}$ & & & 5,00 & 5,00 & 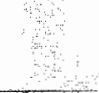 \\
\hline
\end{tabular}

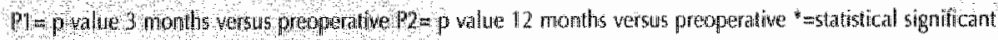

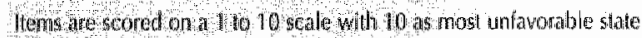

Table 4: Resulls for disease specific questions

\section{Morbidity}

The patient with the reversed laparoscopic approach was readmitted for rebleeding at a port site. One patient had obstructed defecation resolved by reversal of a prior rectopexy and is restored in health.

Parastomal infections were seen 4 times and two of them required surgery. One stoma had a tendency to become stenotic; daily dilatation with a larger diameter catheter prevents this from happening. Reflux of enema fluid was mostly resolved by applying gauze over the stoma. In 3 patients application of a gastrostomy button resolved direct reflux after irrigation. However, in 4 patients there was still a major reflux, even from cecal contents. Three of them were not resolved and got subsequent surgery. In the remaining patient colostomy plugs resolved this problem.

Three of these patients with major leakage had an ileocecostomy. 


\section{Discussion}

With regard to the stoma problems, it seems that the use of the ileocecal valve as a continence mechanism is not the way to go, as 3 out of 5 had major leakage of cecal content. The cause of slow transit constipation might also effect function of this valve. A stapled tubularized colon flap may be an alternative to the ileocecostomy in appendectomized patients.

The improvement in anxiety and depression in successfully treated patients is remarkable, although relations between transit time and anxiety have been mentioned ${ }^{13}$.

The working mechanism of antegrade enemas was always thought to be dependent on dilution and direct propulsion of the fecal mass. Mainly because of this, some authors rejected the idea of this cecal access ${ }^{14}$. Recent research ${ }^{15}$ seemed to show evidence that perhaps distension of the right-sided colon causes propulsive activity of the entire colon.

Operative procedures for slow-transit constipation are major surgical procedures with sometimes disappointing results with regard to associated symptonis. Only one of the patients with the final subtotal colectomy is now free from any of these symptoms and scores zero on the applied constipation scale.

Cecal access is an operation that can be done in short stay surgery. This minimally invasive procedure has good outcome in a majority of patients with serious improvement in symptoms. Failure of the procedure allows further surgery without a problem.

\section{ACKNOWLEDGEMENT}

We would like to thank Dré Karthaus Sr., M.D., Ph.D for his excellent artwork. 


\section{REFERENCES}

1. Pfeifer 1 , Agachan F, Wexner SD. Surgery for constipation: a review. Dis Colon Rectum $1996 ; 39: 44460$.

2. Nyam DC, Pemberton JH, Istrup DM, Rath DM. Long-term results of surgery tor chronic constipation. Dis Colon Rectum 1997; 40:273-9.

3. Mollen RM, Claassen AT, Kuijpers JH. The evaluation and treatment of tunchonal constipation. Scand/ Gastroentero/ 1997; 223:8-17.

4. Ghosh S, Papachrysostomou M. Babol M, Easwood MA. Long-term results of subtotal colectomy and evidence of noncolonic involvement in patients with idiopathic slowtransit constipation. Scand/ Gastroenterd. 1996; 31:1083-91.

5. Malone PS, Ranstey PG, Kiely EM. Prelininary report: the antegrade continence enema. Lancet 1990; 336:1217-8.

6. Griffiths DM Malone PS. The Malone antegrade continence enema. I Pediatr Strg $1995 ; 30: 68-71$.

7. Krogl $\mathrm{K}$, Laurberg S. Malone antegrade continence enema for faecal incontinence and constipation in adults. Br / Surg 1998; 85:974-7.

8. Hill I. Stott S, Maclennan I. Antegrade enemas for the treatment of severe idiopathic constipation. Br / Surg 1994; 81:1490-1.

9. Dick AC, MCCallion WA, Brown S, Boston VE. Antegrade colonic enemas. in / Surg $1996 ; 83: 642-3$.

10. Kiely $\mathbb{E} M$, Ade Ajayi $N$. Wheeler $R$. Antegrade continence enemas in the management of intractable faecal incontinence. I R SOC Med 1995; 88:103P.4P.

11. Webb HW, Barraza MA, Crump JM. Laparoscopic appendicostony for mamagement of fecal incontinence. / Pediatr Surg 1997; 32:457-8.

12. Agachan $F$, Chen T, Preifer I, Reissman P. Wexner SD. A constipation scoring system to simplify evaluation and management of constipated pationls. Dis Cokm Recrum 1996; 39.681-5.

13. Devroede $G$, Girard $G$, Bouchoucha M, Roy T, Black R, Camerlain M, et all, Idiopathic constipation by coloric dysfunction. Relationship with personality and anxiety. Oig. Dis Sci $9989 ; 34: 1428-33$.

14. Haghes SF, Willams NS. Antegrade enemas for the treament of scvere idiopaltio Constipation letter; comment. Br/Surg 1995; 82:567

15. Brown 1. Lee 5 , Vales $\mathrm{P}$ et al. Ambulatory manometry of the right colon in slow transit. constipation and effect of antegrade lavage. Dis Colon Rec tum 1999;43: A 49. 


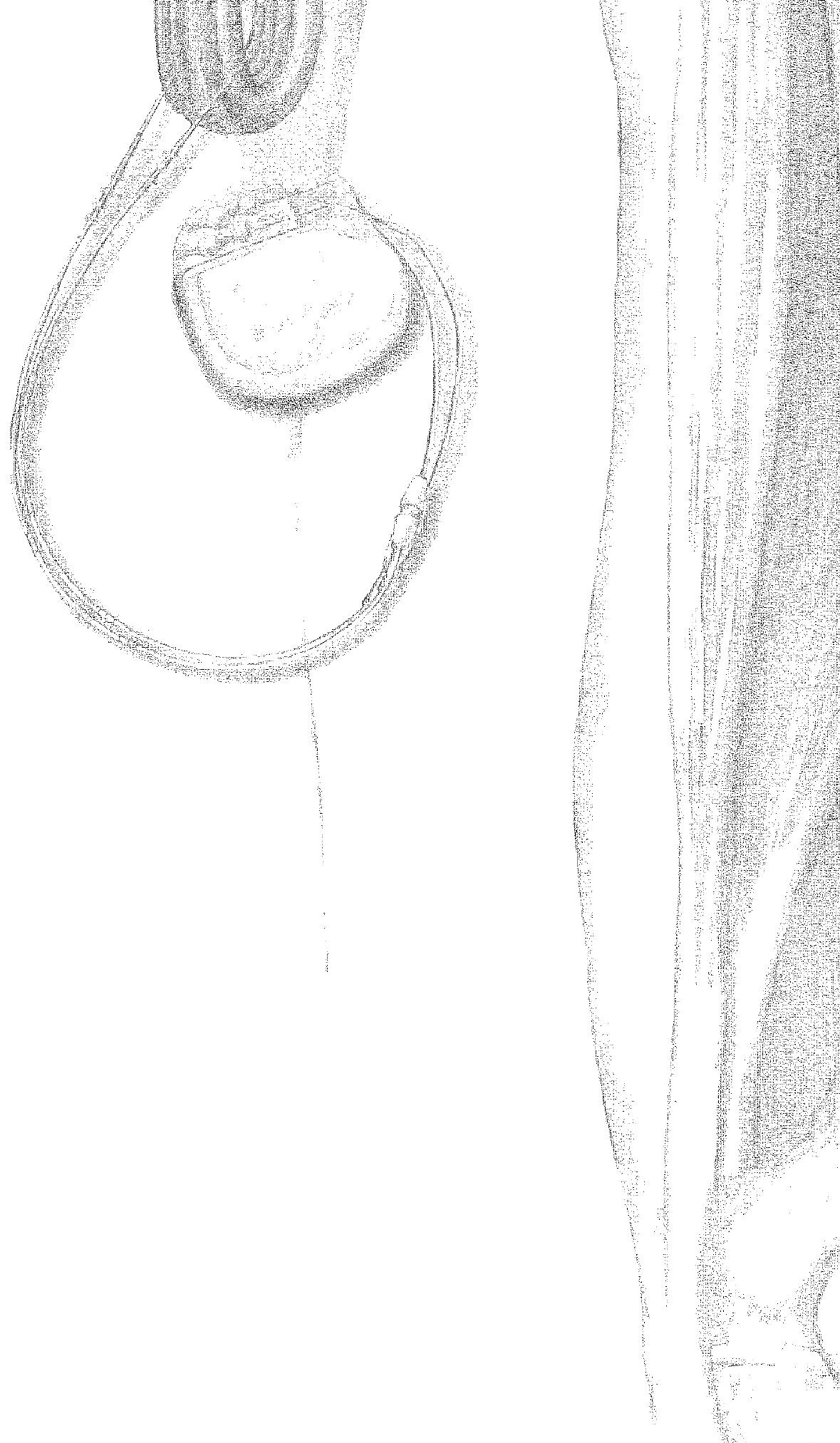




\section{ChAPTER 2}

In this chapter outcome and adverse events in large group of patients with dynamic graciloplasty are presented. Data of 200 consecutive patients with a follow-up of at least 2 years (mean 261 (sd 132) weeks) were analysed in a prospective manner. Overall success rate was $72 \%$. Once continent, patients remained continent. Median IPG survival until battery expiration was 405 weeks, longer than estimated". Complications were frequent but treatable. Disturbed evacuation remained a problem in $16 \%$ of all patients. There is evidentially a steep learning curve. All patients were categorised in groups following the time of procedure. In the last group of patients technically the procedure tends to improve but clinical outcome does not.

\section{CHAPTER 3}

In our initial experience the Dynamic Graciloplasty was performed in two stages. In the first stage the graciliswrap around the anal canal was made and in a later stage the electrodes and IPG were implanted. This was done to prevent infectious complications by not combining a contaminated perianal operation with the implantation of body foreign material. To prove whether this was really necessary, a comparalive study was undertaken. In this prospective matched control study, two groups of 13 patients were matched for age, gender and etiology. Group I had transposition and transplantation combined, group II underwent these procedures separately with a six weeks interval. Continence, manometry, stimulation parameters, quality of life results and adverse events were recorded. After a mean 521 days follow-up infection rates were comparable in both groups as were continence rates, morbidity, anal manometry, stimulation parameters and quality of life. Obviously this study was heavily underpowered, but nevertheless we believe a single procedure avoids the need for an extra hospital admittance and operation without a great increase in risk. After completion of this study the one stage approach was the standard procedure in dynamic graciloplasty in our clinic.

\section{CHAPTER 4}

In dynamic graciloplasty there are two different ways of performing this operation, either with the use of an epineural (the London method) or an 
intramuscular located electrode (the Maastricht method). In the London method one might expect a more efficient stimulation, as all the muscle fibers will contract at a probably low stimulation voltage. However exploration of this nerve and anchoring the electrodes might create morbidity. To compare the results and complications of epineural versus intramuscular stimulation in dynamic graciloplasty, London data (retrospectivelly collected) and Maastricht data (prospectively collected) were clustered. A successful outcome was achieved in 50 out of 90 patients in the London and 148 out of 200 in the Maastricht cases. Surgery for electrode failure or dislocation was performed in 21 patients of the London and four of the Maastricht patients. The stimulation voltages were about the same in both techniques over a period of 10 years. The high number of electrode failures in the London series may have been due to inferior equipment. After switching to the same material as was used in the Maastricht series, both methods became more comparable.

\section{CHAPTER 5}

In this prospective study 7 patients were evaluated, who underwent an abdomino-perineal resection in the past and proved to have unbearable problems with their stoma. All had a secondary pull-through and double dynamic graciloplasty, mean $8.5(1.1-34.8)$ years after the APR. In five patients continence was regained, two were reversed to colostomy due to several complications. Patients who had a successful outcome also suffered from numerous complications, with a total in-hospital stay of mean 73.8(27-167) days, mean $3.1(1-6)$ additional operations and 1.8(0-4) readmissions. Secondary anorectal reconstruction after APR is feasible, but with a high morbidity. Due to this morbidity the secondary procedure was stopped in our clinic in the beginning of 1997. However TAR immediately after APR is still an acceptable alternative for a permanent colostomy.

\section{CHAPTER 6}

Palients with implanted metal material are excluded from magnetic resonance imaging. Fear of migration of the implant as well as heat development lead to this absolute contraindication. There are many patients for whom MRI is the best tool to detect fistulas, cysts, tumor recurrence, etc or to study malfunctioning graciloplasties. This in vitro study tried to determine the safety of MRI in patients 
with implanted electrodes and pulse generators after dynamic graciloplasty. Temperatures were measured with fiberoptic probes around the devices in a cadaver model. Current was measured with an oscilloscope connected to electrodes and IPG. Movement and IPG parameter setting were observed before, during and after testing. Minor temperature increase under $1^{\circ} \mathrm{C}$ were observed around the electrodes. Amplitudes measured were within the range of -1 and +1 Volt. No movement or changing of IPG parameters was noted. All changes were well within physiological ranges. Dynamic graciloplasty should not be a contraindication for high field strength MRI.

\section{ChAPTER 7}

Some of the patients with impaired evacuation after dynamic graciloplasty were shown to have slow transit constipation, a condition that was not observed during their period of incontinence. This prospective study looked at the outcome of a minimal invasive intervention for antegrade irrigation in patients with slow transit constipation. 12 patients with a median defecation frequency of once a week were evalluated pre-operatively, employing marker-transit studies, defecography, manometry, colonoscopy and quality-of-life-assessment. All patients subsequently received an enema access, placed in the lower right abdomen. Employing various enema regimes, frequent defecation (median 1 daily) without major complications was established. In 4 cases subtotal colectomy was required in the long run. Several aspects of the quality of life improved, as did some associated symptoms. Overall constipation score2 dropped from median 21,5 to 5,5 . This cecal access for antegrade colon enemas in medical therapy resistant slow-transit constipation is a minimally invasive procedure with promising results.

\section{Discussion}

Though we believe dynamic graciloplasty is a good treatment for end-stage fecal incontinence, there are more choices of therapy in this field nowadays. Failed repair or a dysfunctional sphincter with disturbed pudendal nerve function is, beside an indication for DGP, also an indication for the artificial bowel sphincter. Outcome seems to be comparable to DGP but adverse events slightly higher ${ }^{3}$. In previously infected tissue, i.e. sphincter trauma due to fistulas, autologous material ought to be preferred. Also lack of covering tissue 
between rectum and vagina forms a contraindication for ABS. The artificial material might have a higher chance of erosion. Failure of the $A B S$ due to infection might also be a reason to convert to DGP.

With the arrival of sacral nerve stimulation/modulation (SNS) we have a new method to deal with incontinence. At this moment it is not clear whether the effect of SNS is purely motor- or sensibility-enhancing or even possibly a combination of the two. Fact is however that patients, eligible for permanent SNS implant, are easily selected with temporary stimulation.

In our clinic temporary stimulation is offered to most of our end stage fecal incontinent patients, who would all undergo dynamic graciloplasty in the past, except for patients with severe sphincter defects on ultrasound. This might lead to a change in outcome in DGP. It might improve as we select patients with severe sphincter trauma without dysfunctional anorectal sensibility. One might also argue that the group of patients, withdrawn from DGP, that has good results with SNS, could also be the group that would have a more beneficial effect from DGP than average.

As SNS is also used in the treatment for constipation, this might be the only surgical treatment that is not associated with disturbed evacuation. It is important to address this issue with patients before performing any kind of surgery for fecal incontinence. The antegrade colon enemas, described in this thesis, were meant for patients with slow transit constipation. There are authors who perform a conduit in a lot of patients with dynamic graciloplasty ${ }^{4}$, especially after total anorectal reconstruction ${ }^{5}$.

The algorithm shown is a guideline for surgical treatment for fecal incontinence. Of course this applies only after conservative measures have been shown not to be successful. 


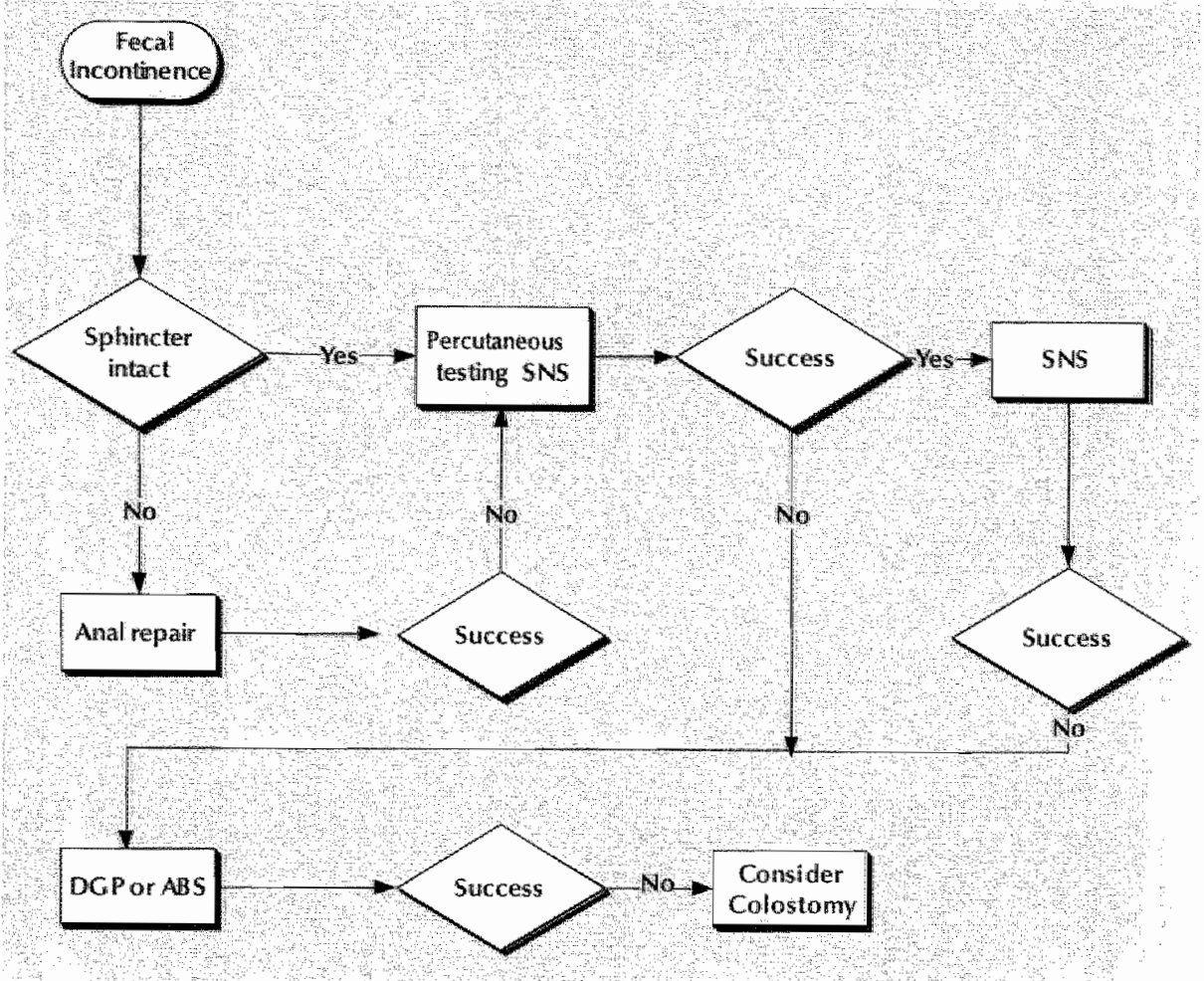

1. Adang, E.M. et al. Cost-effectiveness of dynamic graciloplasty in patients with focal incontinence. Dis Colon Recum, 1998. 41(6): p. 725-33; discussion 733-4.

2. Agachan, F, et al., A constipation scoring system to simplify evaluation and management of constipated patients. Dis Colon Rectum, 1996. 396): p. 681-5.

3. Wong, W.D., et al. The safely and efficacy of the artificial bowel sphtincter for fecal incontinence: results from a multicenter cohor study. Dis Colon Rectum, 2002, 45(9):p. 1139-53.

4. Saunders, J.R., A.J. Eccersley, and N.S. Williams, Use of a continent colonic conduit for treatment of refractory evacuatory disorder following construction of an elactrically stimulated gracilis neoanal sphincter. Br/Surg, 2003 . 900 17 i: p. 1416-21.

5. Saunders, I.R., N.S. Williams, and A.J. Eccerstey, The combination of electrically stimulated gracilis neoanal sphincter and continent colonic conduit: a step forward for total anorectal reconstruction? Dis Colon Rectum, 2004. 47(3): p. 354-63; discussion $363-6$. 


\section{Samenvatting en discussie}




\section{Samenvatting en discussie}

मेग

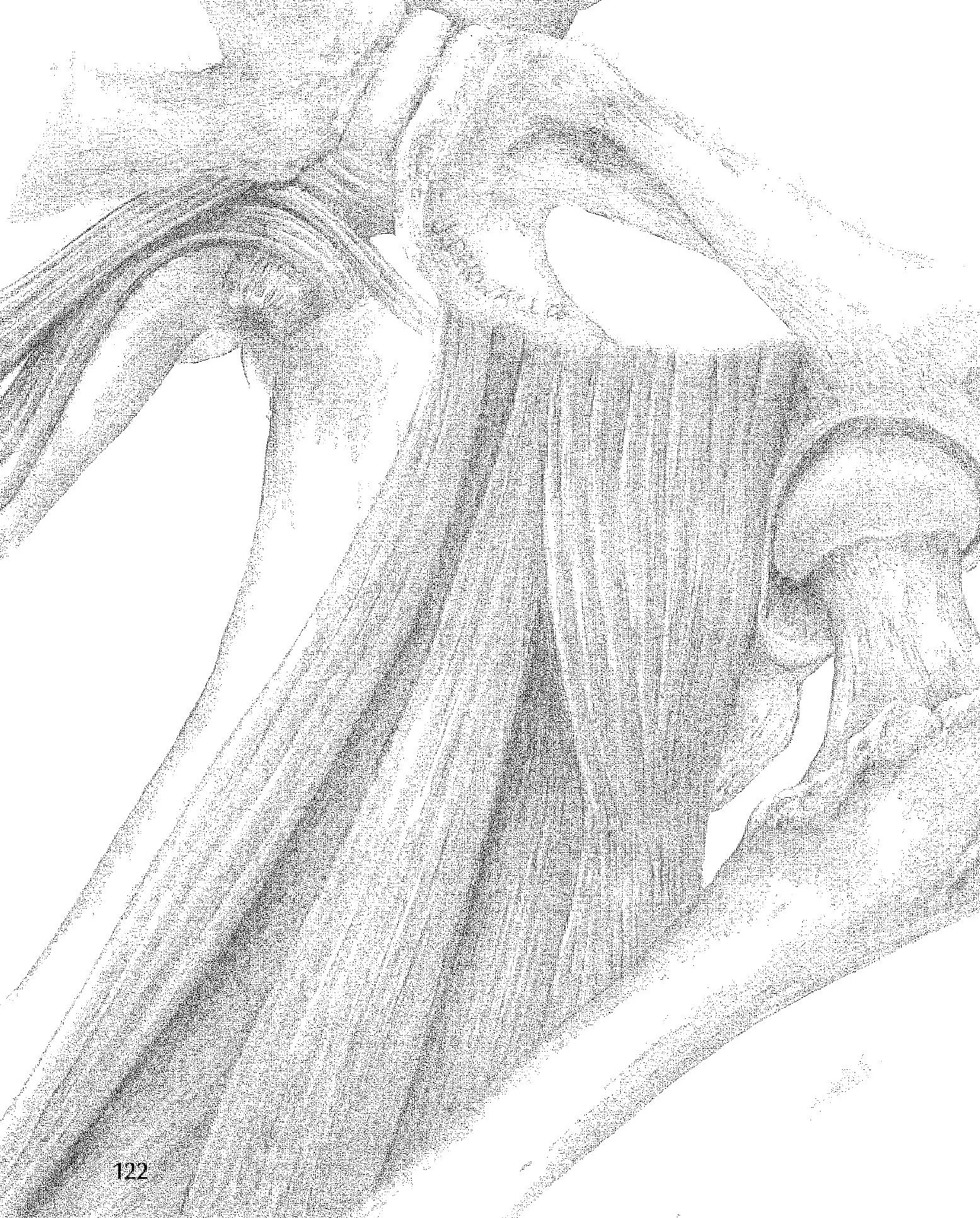




\section{HOOFDSTUK 2}

In dit hoofdstuk worden resultaten en complicaties van een grote groep patiënten met dynamische gracilisplastiek (DGP) gepresenteerd. Data van 200 achtereenvolgende patiënten met een follow-up van ten minste 2 jaar (gemiddeld 261 (sd 132) weken) werden prospectief geanalyseerd. Het totale succes percentage was $72 \%$. Indien patiënten continent werden, bleven zij dit ook. Mediane IPG-batterij levensduur was 405 weken, langer dan oorspronkelijk geraamd'. Complicaties kwamen frequent voor, maar waren behandelbaar. Bemoeilijkte stoelgang bleef een probleem in $16 \%$ van alle patiënten. Er is een duidelijke, steile, leercurve. Alle patiënten werden ingedeeld in historische groepen. In de laatst behandelde groepen werd technisch gezien steeds betere resultaten geboekt, echter zonder te leiden tot klinische verbetering.

\section{HOOFDSTUK 3}

Initieel werd de dynamische gracilisplastiek verricht in twee operaties. Tijdens de eerste werd de $M$. Gracilis rondom het anale kanaal gebracht. In de tweede operatie werden de elektroden en de IPG geïmplanteerd. Dit werd zo gedaan ter preventie van infectieuze complicaties door een gecontamineerde perianale operatie niet te combineren met implantatie van corpora aliena. Om te onderzoeken of dit werkelijk noodzakelijk was werd een prospectieve matched-control studie opgezet. Twee groepen van ieder 13 patiënten werden gematched voor leeftijd, geslacht en oorzaak. In groep I werden transpositie van de spier en implantatie van pacemaker en elektroden gecombineerd. In groep II werden deze ingrepen afzonderlijk gedaan met een tussenpoos van 6 weken. Continentie, manometrie resultaten, stimulatie parameters, kwaliteitvan-levenstudies en complicaties werden bijgehouden. Na een gemiddelde follow-up van 521 dagen waren infectiepercentages vergelijkbaar in beide groepen, evenals de continentie, morbiditeit, manometrie resultaten, stimulatie parameters alsook kwaliteit-van-leven. Deze studie had niet de statistische power die rekenkundig gezien nondzakelijk was, desalniettemin concluderen we dat een enkelvoudige procedure een extra operatie en opname bespaart zonder een grote toename in morbiditeit. Na beëindiging van deze studie werd de eenstaps operatie de standaard procedure voor dynamische gracilisplastiek in onze kliniek. 


\section{HoOfDSTUK 4}

Voor dynamische gracilisplastiek zijn er twee verschillende manieren om deze procedure uit te voeren, hetzij met een epineurale (de Londen methode) of een intramusculaire geplaatste elektrode (de Maastricht methode). Bij de Londen methode zou men een meer efficiënte stimulatie verwachten, daar alle spiervezels vermoedelijk zullen contraheren bij een lagere voltage. Exploratie van de zenuw en verankering van de elektroden kunnen echter bijdragen aam eventuele morbiditeit. Om resultaten en complicaties van epineurale versus intramusculaire stimulatie voor dynamische gracilisplastiek te vergelijken, werclen retrospectief verzamelde data uit Londen en prospectief verzamelde data uit Maastricht geclusterd. Bij 50 van 90 patiënten uit Londen werd een positief resultaat wat continentie betreft geboekt, versus 148 van 200 patiënten uit Maastricht. Hernieuwde operatie voor problemen met elektroden was noodzakelijk bij 21 Londense patiënten en bij 4 Maastrichtse. De stimulatie voltages waren voor beide technieken gelijk. Het hoge aantal elektroden-prablemen in de Londense serie zou verklaart kunnen worden door inferieur materiaall. Nadat in Londen hetzelfde materiaal werd gebruikt als in Maastricht werden de resultaten vergelijkbaar.

\section{HoOfDSTuk 5}

In deze prospectieve studie werden 7 patiënten geëvalueerd, die allemaal reeds een abdomino-perineale resectie (APR) hadden ondergaan en bewezen ondraaglijke problemen hadden met hun colostoma. Allen ondergingen een secundaire pull-through en dubbele dynamische gracilisplastiek (totale anorectale reconstructie TAR), gemiddeld $8,5(1,1-34,8)$ jaren na hun APR. In vijf patiënten werd continentie bereikt. Bij twee patiënten was het wederom aanleggen van een colostoma noodzakelijk in verband met diverse complicaties. Ook bij patiënten met een gunstig eindresultaat was er sprake van talrijke complicaties, met een cumulatief gemiddeld ziekenhuisverblijf van $73,8(27$ 167) dagen, gemiddeld $3,1(1-6)$ extra ingrepen en 1,8(0-4) heropnames. Secundaire anorectale reconstructie na APR is haalbaar, maar met een hoge morbiditeit. Door deze morbiditeit is onze kliniek gestaakt met de secundaire procedure vanaf begin 1997. Desondanks is een TAR aansluitend aan een APR een acceptabel alternatief voor een permanent colostoma. 


\section{HoOFDSTUK 6}

Patiënten met geïmplanteerd metalen materiaal zijn uitgesloten voor het ondergaan van magnetic resonance imaging (MRI). Vrees voor migratie van het implantaat alsook hitteontwikkeling heeft geleid tot een absolute contraindicatie. Voor vele patiënten is MRI toch het beste diagnosticum voor fistulae, cystes, tumor recidief, etc en ook om slecht functionerende gracilisplastieken te onderzoeken. Met deze studie werd getracht de veiligheid te bestuderen van MRI in patiënten met geïmplanteerde elektroden en pulsegeneratoren (IPG) na dynamische gracilisplastiek. Met behulp van glasfiber sensoren werd de temperatuur gemeten rond de implantaten in een kadaver model. Voltage werd gemeten met een oscilloscoop, verbonden aan de elektroden en IPG. Beweging en IPG parameter werden geobserveerd voor, gedurende en na testen. Kleine temperatuurstijgingen van minder dan $1^{\circ} \mathrm{C}$ werden wargenomen rond de elektroden. Amplitudes binnen het bereik van -1 tot +1 volt werden gemeten. $\mathrm{Er}$ werden geen bewegingen of veranderingen van de $\mathrm{P} G$ parameters waargenomen. Alle veranderingen waren binnen fysiologische grenzen. Dynamische gracilisplastiek hoeft geen contraindicatie voor MRI onderzoeken te zijn.

\section{HOOFDSTUK 7}

Een aantal patiënten met bemoeilijkte stoelgang na dynamische gracilisplastiek bleek te lijden aan slow-transit constipation (STC). Deze aandoening was gedurende hun periode van incontinentie niet waargenomen. Onderwerp van deze prospectieve studie was het resultaat van minimaal invasieve interventie voor antegrade darmspoeling bij patiënten met medicamenteus onbehandelbare STC. 12 patiënten met een mediane defecatiefrequentie van eenmaal per week werden pre-operatief geëvalueerd middels marker-transit onderzoek, defecografie, manometrie, coloscopie en kwaliteit-van-leven-onderzoek. Bij alle patiënten werd een stoma voor spoelingen aangelegd in de rechter onderbuikshelft. Met diverse spoelingsregimes, werd een mediane defecatiefrequentie van eenmaal daags bereikt zonder grote complicaties. In 4 gevallen was uiteindelijk een subtotale colectomie noodzakelijk. Diverse aspecten van kwaliteit-van-levenonderzoek verbeterde, evenals een aantal geassocieerde symptomen. De gezamenlijke constipatie score ${ }^{2}$ daalde van mediaan 21,5 naar 5,5 . Deze coecale toegang voor antegrade darmspoeling in medicamenteuze therapieresistente STC is een minimaal invasieve procedure met veelbellovende resultaten. 


\section{Discussie}

Ofschoon we geloven dat DGP een goede behandeling is voor onbehandelbare fecale incontinentie, zijn er tegenwoordig meerdere behandelingsopties op dit vlak. Een niet-geslaagd sphinkterherstel of een disfunctionele sphinkter met gestoorde nervus pudendusfunctie, is, behalve een indicatie voor DGP, ook een indicatie voor de artificial bowel sphincter (ABS). Resultaten zijn vergelijkbaar met DGP maar complicaties wat frequenter ${ }^{3}$. Waar er sprake is geweest van infectie, bijvoorbeeld sphinkterletsel door fistels, heeft: autoloog materiaal de voorkeur. Gebrek aan bedekkend weefsel tussen rectum en vagina is ook een contra-indicaties voor ABS. Het kunststofmateriaal geeft een grotere kans op erosie. Bij falen van ABS door infectie is er wellicht ook een indicatie om tot DGP over te gaan.

Met de komst van sacrale zenuw stimulatie/modulatie (SNS) is er een nieuwe methode voorhanden om incontinentie te behandelen. Op dit ogenblik is nog niet duidelijk of het effect van SNS een puur motorisch of proprioceptieve respons is, dan wel een combinatie. Patiënten die in aanmerking kunnen komen voor permanente SNS implantatie, zijn met tijdelijke stimulatie eenvoudig te selecteren.

Op clit ogenblik wordt in onze kliniek tijdelijke stimulatie toegepast bij alle patiënten met onhanteerbare fecale incontinentie die voorheen in aanmerking zouden komen voor DGP, uitgezonderd degene met ernstig echografisch geduid sphinkterletsel. Dit zal wellicht lijden tot een andere resultaten voor de DGP. Het kan verbeteren als we patiënten kunnen selecteren met ernstig sphinkterletsel zonder gestoorde anorectale sensibiliteit. Van de andere kant kan men ook redeneren dat de patiëntengroep die een goed resultaat boekt met SNS en aan de DGP wordt onttrokken, nou net die groep is die met DGP ook een bovengemiddeld resultaat zouden hebben.

Ondat SNS ook gebruikt wordt als behandeling voor obstipatie, zal dit waarschijnlijk de enige chirurgische behandeling zijn die niet gepaard gaat met gestoorde evacuatie

Het is van het grootste belang om het evacuatieprobleem met patiënten te bespreken voordat enige vorm van chirurgie voor fecale incontinentie wordt toegepast. De antegrade darmspoeling, die in dit proefschrift wordr beschreven, is bedoelt voor slow-transit constipatie. Er zijn auteurs die een dergelijk toegang creëren bij een aanzienlijk aantal DGP patiënten ${ }^{4}$, en met name na de totale anorectale reconstructie ${ }^{5}$.

Het getoonde algoritme is een hulpmiddel indien men tot chirurgisch behandeling van fecale incontinentie wil overgaan. Uiteraard geldt dit alleen indien alle conservatieve maatregelen gefaald hebben. 


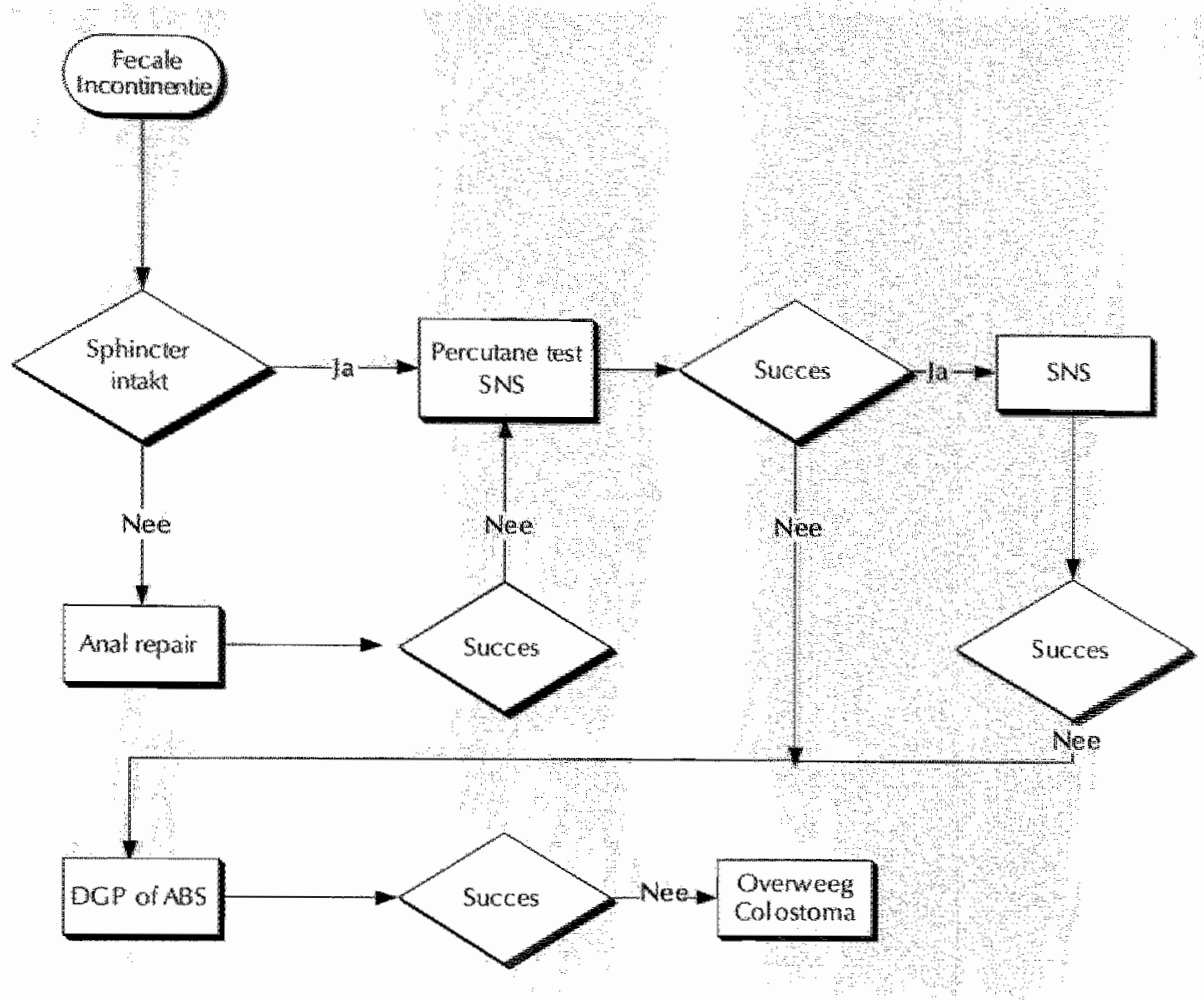

1. Adang. E.M. ef al. Cost-effectiveness of dynamic graciloplasty in patients with fecol incontinence. Dis Colon Rectum, 1998, 4167: p, 725-33; discussion 733-4.

2. Agachan, F., al. A constipation scoring system to simplify ewaluation and management of constipated patients. Dis Colon Rectum, 1996. 3966): p. 687-5.

3. Wong. WD., al., The safely and effeacy of the artificial bowel sphincter for focal incontinence: results from a multicenter cohort study. Dis Colon Recturn, 2002. 4509 : p. $1139.5 \%$

4. Saunders, I.R. A.J. Eccersley, and N.S. Williams, Use of a continent colonic conduit for freament of refractory evacuatory disorder following construction of an electrically stimulated gracilis neoanal sphincter. Br/ Surg, 2003. 90111: p. 1416-21.

5. Saunders, J.R. N.S. Williams, and A.J. Eccersley. The combination of elfectically stimulated gracilis neoanal sphincter and continent colonic conduit: a step forward for total anorectal reconstruction? Dis Colon Recum, 2004. 47(3): p. 354-63; discussion 363-6. 


\section{List of abbreviations}

$\begin{array}{ll}\text { AA } & \text { Anal Atresia } \\ \text { ACE } & \text { Antegrade Colon Enemas } \\ \text { ABS } & \text { Artificial bowel sphincter } \\ \text { APR } & \text { Abdomino-Perineal Resection } \\ \text { DGP } & \text { Dynamic graciloplasty } \\ \text { EAS } & \text { External anal shincter } \\ \text { EMG } & \text { Electromyography } \\ \text { IAS } & \text { Internal anal sphincter } \\ \text { IBD } & \text { Inflammatory Bowel Disease } \\ \text { IPG } & \text { Implantable pulse generator } \\ \text { LMNL } & \text { Lower motor neuron lesion } \\ \text { PNTML } & \text { Pudendal Nerve Terminal Motor Latency } \\ \text { RAIR } & \text { Recto Anal Inhibitory Reflex } \\ \text { SNS } & \text { Sacral nerve stimulation } \\ \text { TAR } & \text { Total anorectal reconstruction with dynamic graciloplasty } \\ \text { TPR } & \text { Total pelvic floor repair }\end{array}$




\section{Publications}

Treatment of fecall incontinence by means of dynamic graciloplasty

Rongen MIGM; Baeten CGMI

Seminars in colon \& rectal surgery; Anal Incontinenence 1997; 8 : 110-115

Total anorectal reconstruction; fact or fiction?

C.C.M.I. Baeten, M.D., Ph.D., M.J. Rongen M.D.

Swiss-Surg. 1997; 3(6): 262-5

Total anorectal reconstruction with a double dynamic graciloplasty after abdomino-perineal resection for low rectal cancer.

Geerdes BP; Zoetmulder FAN; Heineman E; Vos EI Rongen MICM; Baeten CGMI

Dis Colon Rectum 1998; 40:698-705.

Secondary coloperineal pull-through and double dynamic graciloplasty after Miles resection; feasible, but with a high morbidity.

Rongen MIGM; Dekker FA; Geerdes BP; Heineman E; Baeten CGMI

Dis Colon Rectum 1999;42:775-81.

High resolution magnetic resonance imaging of the anorectal region without an endocoil.

Beets-Tan RGH, Beest GL, van der Hoop AG, Borstlap ACW, Boven H van, Rongen MJM, Baeten, CGMI.; van Engelshoven, IMA.

Abolominal maging 1999;24:576-81

One step versus two step procedure in dynamic graciloplasty

Rongen MGM: Adang E; Gerritseir van der Hoop A: Baten CGM!

Colorectal diseases 2001:3:51-57

Comparison of epineural or intramuscular nerve electrodes for stimulated graciloplasty. Konsten 1. Rongen M. Ogunbiyi OA, Darakhshan A, Baeten CG, Williams NS.

Dis Calon Rectum. 2001 Apr;44(4):581-6.

Baten CGMI, Whudag O, Rongen M

Dynamic graciloplasty for fecal incontinence.

Microsurgery $2001 ; 21616230-4$. 


\section{Publications}

Long term results of dynamic graciloplasty for fecal incontinence.

MJCM Rongen, Ö. Uludag, K El Naggar, BP Geerdes, I Konsten CGMI Baeten

Dis Colon Rectum. 2003 Jun; $46(6): 716-21$

The effects of high field strength MRI on electrodes and pulse generator in dynamic gracilopilasty

Rongen MIGM, Beets-Tan RGH, Backes WH, Baeten CGMI

Colorectal Dis. 2004 Mar;6(2):113-6.

Dynamic graciloplasty in patients born with an anorectal malformation.

Koch SM, Uludag $O$, Rongen MI, Baeten CG, wan Gemert W.

Dis Colon Rectum. 2004 Oct:47(10):1711-9.

\section{CHAPTER IN BOOK}

\section{Graciloplastie dynamique}

Baeten CGMI, Rongen MJCM

In 'L'Incontinence fécale el urinaire'

Marti MC, Roche B. Médecine\& Hygiène Chene-Bourg/Geneve 2000

Managing functional problems following dynamic graciloplasty

Baeten CGMI, Rongen MIGM

In 'Complex anorectal disorders: investigation and management'

Wexner SD, Zbar AP, Pescatori M. Springer Verlag London 2005 


\section{Curriculum Vitae}

Mart-Jan Rongen werd op 12 meil 1963 geboren in Venlo. Na de lagere school bezocht hij het Marianum College in zijn geboorteplaats alwaar hij in 1981 het WO diploma behaalde. Daarna studeerde hij aan de Rijksuniversiteit Utrecht Geneeskunde, enige jaren onderbroken voor de studie Nederlandse taal en letteren. In 1992 werd het artsexamen behaald. Aansluitend vervulde hij zijn militaire dienstplicht als officier-arts. In 1994 begon hij zijn werkzaamheden bij de vakgroep algemene heelkunde in het Academisch Ziekenhuis Maastricht, eerst als AGNIO en vanaf mei 1996 ais arts-onderzoeker colorectale chirurgie onder leiding van Dr. CGMI Baeten. In september 1999 startte hij daar met zijm opleiding chirurgie (Opleider 1999-2000 Prof. Dr. G. Kootstra, 2000-2002 Prof. Dr. MJHM Jacobs). Vanaf oktober 2002 werd de opleiding vervolgd bij de vakgroep chirurgie in het Maasland ziekenhuis in Sittard (Opleider Dr. AG Hoofwijk). Na het beëindigen van zijn opleiding in augustus 2005 is hij daar als fellow gastrointestinale/ oncologische chirurgie werkzaam.

Hij is getrouwd met Marie-José Woertman. Samen hebben ze drie kinderen, Sebastiaan, Julie en Suze.

Mart-lan Rongen was born May 12th 1963 in Venlo, the Netherlands. He attended the secondary school Marianum College in his hometown from 1975 to 1981 . The medical study was started at the Rijksuniversiteit Utrecht, interrupted for a few years for a study Dutch language and literature. After obtaining his medical degree in 1992, he served as a medical officer in the Royal Dutch Army. He started to work at the department of surgery at the university hospital of Maastricht from 1994 on, first as a resident. From May 1996 he worked as a colorectal research fellow under supervision of CGMI Baeten. Surgical training was started in this institution in September 1999 (Head 1999-2000 Prof. Dr. G. Kootstra, 2000-2002 Prof. Dr. MUHM Jacobs). In October 2002 he continued his training at the department of surgery at the Maasland ziekenhuis in Sittard (Head AG Hoofwijk). After ending the training in August 2005, he is currenlly working there as a fellow in gastrointestinal/ oncological surgery.

He is married to Marie-José Woertman. They have three children, Sebastiaan, Julie and Suze. 


\section{Dankwoord}

Mijn promotor Cor Baeten. Beste Cor, standing on the shoulders of giants, zo voelde ik me, hoewel je postuur anders deed vermoeden. In jouw kielzog ging ik de wereld rond, in aangenaam gezelschap van een levensgenieter. $1 \mathrm{k}$ heb je hoog zitten, niet alleen als medicus, maar ook als mens. Eerlijkheid, ook bij slechte resultaten. Waar in academische kringen om carrièreperspectieven dubbele agenda's niet ongewoon zijn, is dit fenomeen je totaal wreemd.

Qua wetenschapsproductie was er sprake van een slow-transit promotie, ondanks je laxerende herhaalde aanmoedigingen. Bedankt voor je geduld en voor de mogelijkheid om onderzoek bij je te doen. Als je de kans krijgt om wetenschappelijk onderzoek te doen met patiëntencontact, met operatietijd, met leuke congressen door de hele wereld, actief en passief, en dat ook nog met een begeleider met een goed gevoet voor humor en een hoop ideeën, dan ben je gezegend. Ik zou het zo weer doen.

De co-promotores Joop Konsten en Wim van Gemert.

Beste loop, je was de eerste in de colorectale onderzoekslijn in Maastricht. In een nieuw veld heb je een karrenspoor achtergelaten dat voor iedereen na je de weg wees. Ook na je promotie bleef je betrokken en je verblijf in Londen was de voorzet voor hoofdlstuk 3 .

Beste Wim. Een grasgroene AGNIO was ik en jouw begeleiding hielp me door een moeilijke start. Juist toen ik mij in de wetenschap wou begeven en ik contact met je had gezocht om me in het metabolisme van obesitas te verdiepen, kon ik bij Cor aan de slag. Uiteindelijk zijn we hier weer met elkaar herenigd.

De leescommissie, de professoren P.B. Soeters, Ph.E.V.A. Van Kerrebroeck, M. Kon en L. Păhlman, wil ik bedanken voor het beoordelen van dit proefschrift. Peter, niet alleen als voorzitter van de leescommissie speel je een rol in mijn professionele leven. Mijn huidige interesse voor Gl chirurgie is mede door jou ontstaan.

Erik Heineman. Voor je vertrek naar Nieuw-Zeeland was je partner in crime met Cor. Je had een heleboel goede ideeën. Het vervolgonderzoek met atresiebiggen is helaas in de kiem gesmoord door de varkenspest. Je enthousiasme is even jeugdig als je patientenpopulatie. 
Arthur Gerritsen van der Hoop. Jouw ideeen waren to the point en goed uitvoerbaar. Ons gezamenlijk kijkje in de Duitse chirurgische keuken heeft in ieder geval genoeg bedenkelijke grappen opgeleverd. De Keulse klofte liggen nog steeds zwaar op mijn maag

Bas Geerdes, mijn voorganger in het onderzoek, je had al een aantal lijnen uitgezet die in dit boekje zijn verwezenlijkt. Jij hebt me na de inwerkperiode altijd bijgestaan. We zien elkaar te weinig.

Kadri el Naggar, mijn opvolger. Als ik aan je denk, word ik weer geconfronteerd met de breekbaarheid van ons leven. Veelbelovend was je, we hebben er alleen niet van mogen genieten door je fatale ongeluk.

Özenç Uludag, alias Eus. Ook jij bleef braaf de database bijhouden zodat ik aan mijn getalletjes kwam. Je bent een echt gezelschapsdier, aangename medereiziger tijdens al die congressen. Nu ben jij aan de beurt. Tevens succes gewenst aan Sacha en Jarno.

Mijn mede auteurs, Regina Beets, Frans Dekker en Eddy Adang. Regina, het begrip 'probleern' is vreemd voor je. Dat is wel zo prettig voor de afhandelingssnelheid bij publicaties, dat heb je met je eigen promotie ook wel bewezen.

Wim Buurman, hoewel je geen directe link had met mijn onderzoek, heb je me wel onderdak verschaft binnen je onderzoeksgroep. Voor methodologische problemen was je mijn eerste en ook beste raadgever. Overigens was je ook nooit beroerd om je mening over wat dan ook te geven, vaak ongevraagd.

Mijn kamergenoten en mede onderzoekers Carlo, Marc, Kees, Francois en Tim. Veel geouwehoerd, gestapt, gespeeld en vooral gelachen. Wie beweert dat het bedrijven van wetenschap saai is?

Dr. Dré Karthaus senior wil ik bedanken voor de fraaie illustraties in hoofdstuk 7 .

John Derwall en Eric Lemmens van D\&L graphics. Volgens mij betekent dat Duvelstoejagers\&Langenachtendoorwerken. Jullie energie lijkt onuitputtelijk.

Mensen van Medtronic. Fons, Charlie, Anneke, Ralph, Ubi, Florence, Juliette, Rob, Mathias, Michael, Jan en alle andere. Sommige van jullie werken er al niet meer. Jullie bereidheid tot ondersteuning was altijd aanwezig, jullie gezelschap altijd aangenaam

Mijn collega-assistenten uit AGIO en AGNIO tijd, voor het delen van lief en leed voor wat betreft opleiding en wetenschap en met name de combinatie hiervan met je sociale leven. 
De vakgroep chirurgie in het AZM, gemoedelijk als altijd, in het bijzonder Jan Tordoir, die me destijds na een zeer kort sollicitatiegesprek als AGNIO aannam.

De collega's en vootheen mijn opleiders in het Maasland żiekenhuis. Luc, Fred, Michiel, Karel, Wil, Harry en Regine. Ik draag een Sittards stempel op mijn voorhoofd en daar ben ik trots op. In het bijzonder duizendpoot Ton Hoofwijk, ook voor methodologische steun.

De dierbare patiënten van mijn onderzoek. Vaak heb ik jullie gezien en met de meeste een vertrouwensband, die uniek is, opgebouwd. Het was dankbaar werk. Jullie hebben me een betere medicus gemaakt.

Verplegend en administratief personeel van de poli, OK, afdelingen en de vakgroep heelkunde

Mijn paranymfen El len en Vincent. Vinnie, Bij het begin van mijn onderzoekstijd werd $i k$ al voorgesteld aan zo'n lange met zijn onafscheidelijke multifunctional urban survival tool. Je werd mijn kamergenoot (tot het te gezellig werd) en vaste broeder bij congressen en daarbuiten voor borrel- en bowlingactiviteiten. In Sittard werden we weer herenigd. Binnenkort mag je academisch je wat meer uitleven in de traumatologie. Zijn er ook Leathermen met reamers en repositieklemmen?

Ellen, toen ik destijds als jonge dokter in den lande aan het solliciteren was, is miln keuze voor Maastricht ook gemaakt vanwege jouw aanwezigheid daar. Al als kind wist je onopgemerkt de spil van sociale netwerken te zijn. Mensen zijn graag in jouw gezelschap en dat is terecht. De kans is groot dat ik binnenkort niet meer bij je in de buurt woon. Ik zal de spontane zondagmiddaginvallen missen.

Mijn ouders, Sjraar en Mariet. Ik heb de nodige keuzes in het leven gemaakt, die het mij niet gemakkelijker hebben gemaakt. Dat geldt nog meer voor jullie. Nooit is er echter een geluid of gebaar van meewarigheid van jullie kant gekomen en hebben jullie me altijd gesteund in die beslissingen.

Mijn kinderen. Sebastiaan, altijd vol welgeformuleerde babbels en stoer gedrag. Je hebt een bijzonder probleemoplossend vermogen en cen gouden hart. Julie, enerzijds ben je een gewoontedier, anderzijds ben je ook niet bang voor nieuwe dingen in het leven. Je wilskracht is ongekend. Suze, je kunt nog niet praten, toch ben je met je onbevangenheid en vrolijkheid een voorbeeld voor ons allen. 
Marie-José, het is niet gemakkelijk om met een chirurg getrouwd te zijn, zeker niet als hij nog in opleiding is en zo nodig wil promoveren. De zorg voor ons gezin ligt voornamelijk in jouw handen, naast je drukke baan. Het lukt je dan ook nog om creativiteit en engagement te tonen en mij en de kinderen nog wat cultuur voor te schotelen. Met jouw gaven had jij in mijn plaats al 10 proefschriften geschreven. Ik hou intens van je. 
NOtITIES 


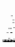

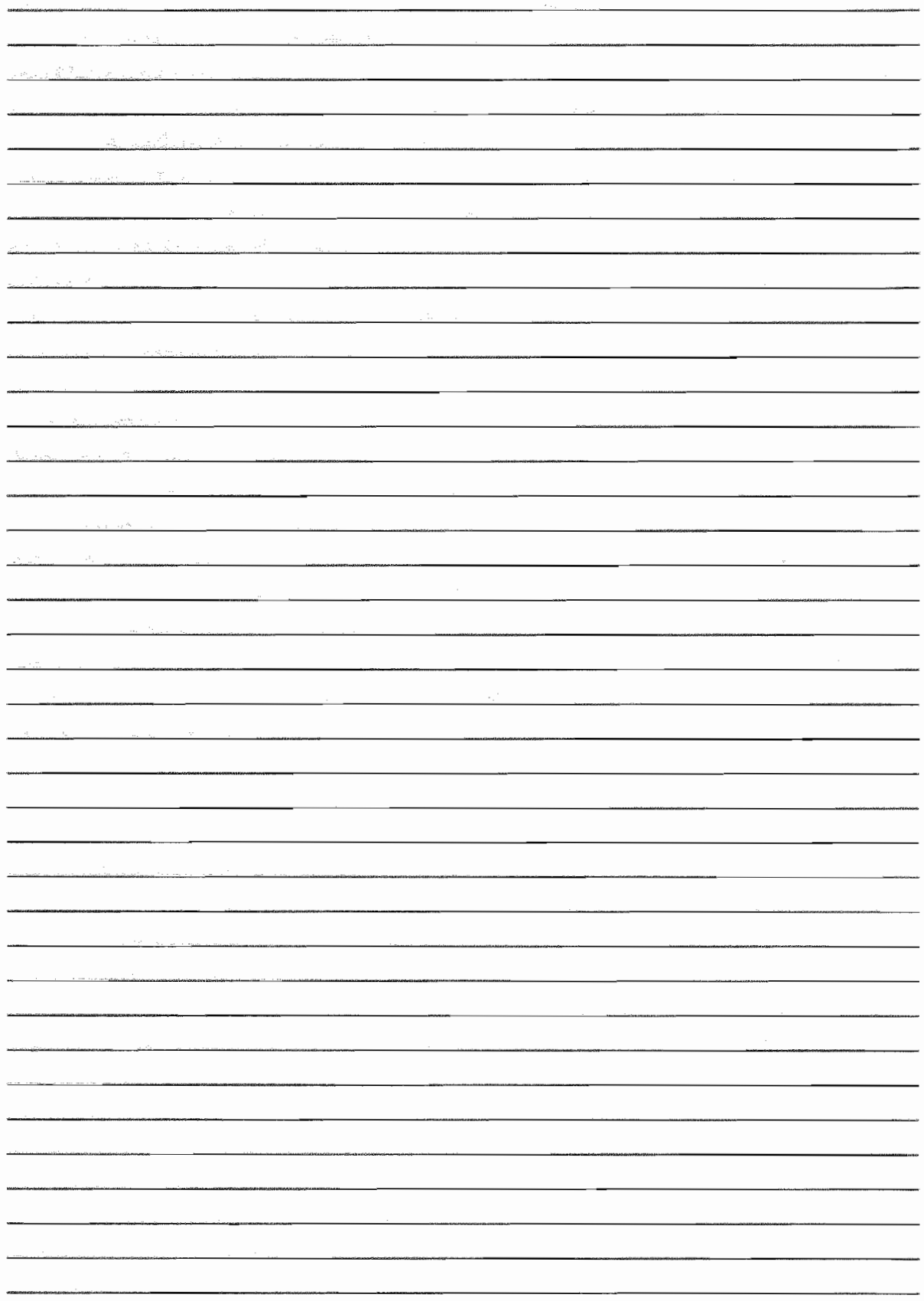

